Prepared in cooperation with the Lower Platte South Natural Resources District

\title{
Emergent Sandbar Dynamics in the Lower Platte River in Eastern Nebraska-Methods and Results of Pilot Study, 2011
}

Scientific Investigations Report 2013-5031 
Cover photograph. Sandbars in the lower Platte River near South Bend, Nebraska. 


\section{Emergent Sandbar Dynamics in the Lower Platte River in Eastern Nebraska- Methods and Results of Pilot Study, 2011}

By Jason S. Alexander, Devin M. Schultze, and Ronald B. Zelt

Prepared in cooperation with the Lower Platte South Natural Resources District

Scientific Investigations Report 2013-5031 


\title{
U.S. Department of the Interior \\ KEN SALAZAR, Secretary
}

\section{U.S. Geological Survey \\ Suzette M. Kimball, Acting Director}

\author{
U.S. Geological Survey, Reston, Virginia: 2013
}

For more information on the USGS - the Federal source for science about the Earth, its natural and living resources, natural hazards, and the environment, visit http://www.usgs.gov or call 1-888-ASK-USGS.

For an overview of USGS information products, including maps, imagery, and publications, visit http://www.usgs.gov/pubprod

To order this and other USGS information products, visit http://store.usgs.gov

Any use of trade, firm, or product names is for descriptive purposes only and does not imply endorsement by the U.S. Government.

Although this information product, for the most part, is in the public domain, it also may contain copyrighted materials as noted in the text. Permission to reproduce copyrighted items must be secured from the copyright owner.

Suggested citation:

Alexander, J.S., Schultze, D.M., and Zelt, R.B., 2013, Emergent sandbar dynamics in the lower Platte River in eastern Nebraska-Methods and results of pilot study, 2011: U.S. Geological Survey Scientific Investigations Report 2013-5031, 42 p. with appendixes. 


\section{Contents}

Abstract

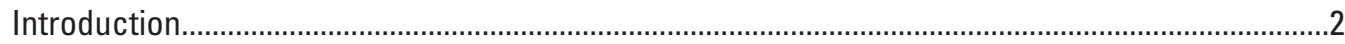

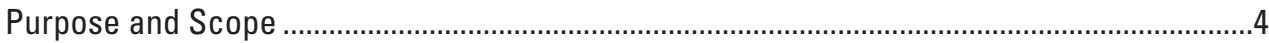

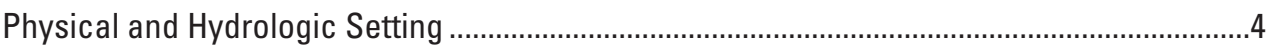

Definitions and Descriptions of Sandbars in the Lower Platte River ........................................5

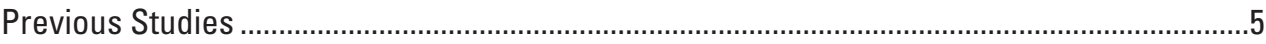

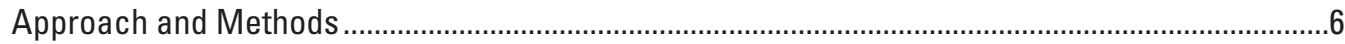

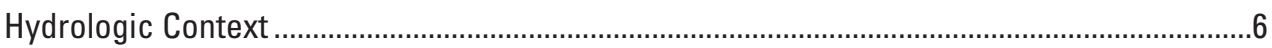

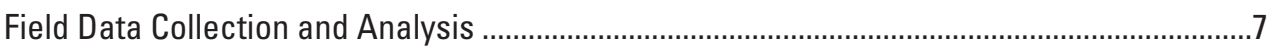

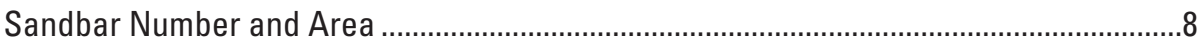

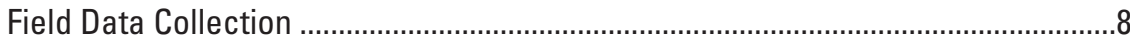

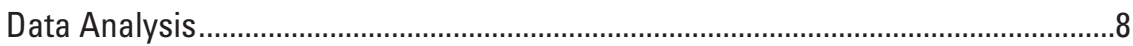

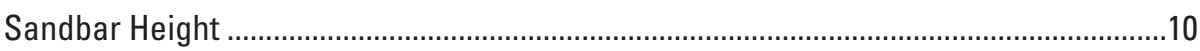

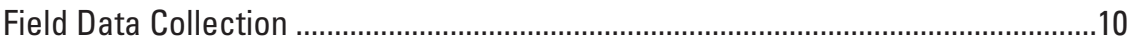

Data Analysis .........................................................................................................

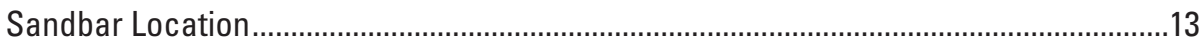

Field Data Collection ............................................................................................

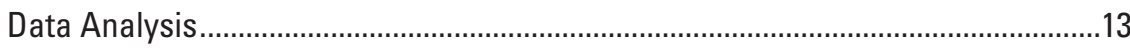

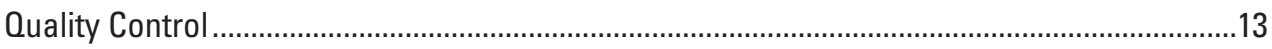

Replicate Surveys of Sandbar Geometry.................................................................

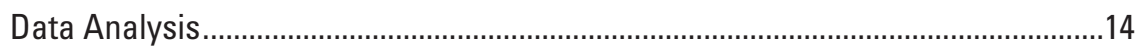

Detailed Surveys of Sandbar Topography ............................................................... 14

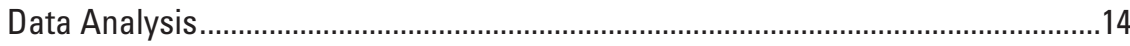

Emergent Sandbar Dynamics in the Lower Platte River .............................................................15

Seasonal Differences in Number and Areas of Emergent Sandbars ......................................15

Seasonal and Longitudinal Changes in Emergent Sandbar Height........................................18

Seasonal Changes in Longitudinal Distribution of Emergent Sandbars ....................................22

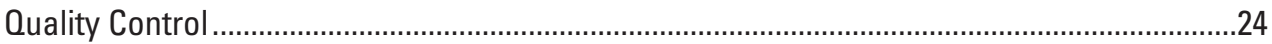

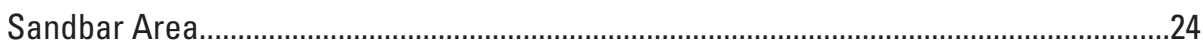

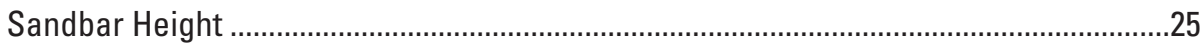

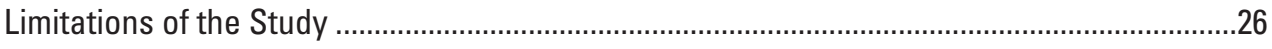

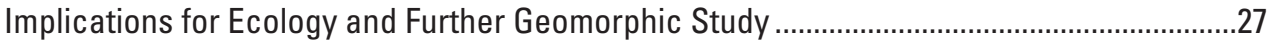

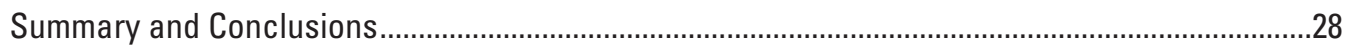

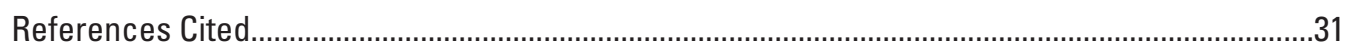

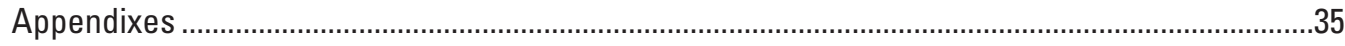

Appendix 1. Estimates of Error in Measured Sandbar Height Associated with Errors in

Estimation of Water Travel Time .............................................................................36

Appendix 2. Validation of Predicted Bar Heights Using Observations of Inundation from Remote Time-Lapse Photographs ........................................................................... 


\section{Figures}

1. Map showing location of lower Platte River study area, U.S. Geological Survey gaging stations, and reconnaissance time-lapse cameras, Nebraska.

2. Hydrograph showing daily average discharge in calendar year 2011 and selected daily discharge statistics for Platte River at Louisville, Nebraska

3. Schematic diagrams showing typical levels and shapes of emergent sandbars in lower Platte River, Nebraska, and associated point spacing methods for surveying sandbar height: $(A)$ streamwise tapering, $(B)$ rectangular, and $(C)$ dissected and tapering .

4. Graphs showing example of stage-correlation method used to estimate travel time of water between gaging stations by $(A)$ comparison of stage hydrographs with various offset hydrographs; and $(B)$ results from correlation analyses comparing downstream hydrograph with various offset hydrographs of upstream stage hydrograph.

5. Aerial photograph map showing examples of point-and-transect spacing of detailed topographic measurements collected with a total-station system, summer 2011, lower Platte River, Nebraska

6. Box-and-whisker plots showing frequency distribution of emergent sandbar area by survey period and sandbar type, lower Platte River study segment, Nebraska, 2011: $(A)$ all bar types, $(B)$ mid-channel sandbars, $(C)$ island-attached sandbars, and $(D)$ bank-attached sandbars

7. Box-and-whisker plots showing frequency distributions of differences in emergent sandbar area among collocated pairs of sandbars between survey seasons by sandbar type, lower Platte River, Nebraska, 2011: (A) spring-summer difference, $(B)$ summer-fall difference, and $(C)$ spring-fall difference.

8. Graph showing cumulative frequency distribution of measured sandbar heights from three survey periods, lower Platte River, Nebraska, 2011.

9. Graphs showing longitudinal distributions of measured sandbar heights from three survey periods in 2011 and river-channel morphometric characteristics, lower Platte River, Nebraska: $(A)$ sandbar heights measured during the spring survey period; $(B)$ sandbar heights measured during the summer survey period; $(C)$ sandbar heights measured during the fall survey period; and $(D)$ bank heights measured during the spring and summer survey periods, channel sinuosity, and unvegetated channel width

10. Box-and-whisker plots showing frequency distributions of measured sandbar heights above river stage at 4,000 cubic feet per second for three survey periods and different bar types, lower Platte River, Nebraska, 2011: $(A-C)$ median measured sandbar heights, and $(D-F)$ maximum measured sandbar heights

11. Bar charts showing longitudinal distribution of emergent sandbar area for three survey periods and net change in emergent sandbar area between river miles 3 and 26, lower Platte River, Nebraska, 2011: $(A)$ spring survey period, $(B)$ summer survey period, $(C)$ fall survey period, and $(D)$ difference in percent of total sandbar area by river mile between spring and fall survey periods

12. Box-and-whisker plots showing frequency distributions of shifts in sandbar areal centroids among collocated sandbar pairs between three survey periods, for different sandbar types, lower Platte River, Nebraska, 2011: $(A)$ between spring and summer survey periods, $(B)$ between summer and fall survey periods, and $(C)$ between spring and fall survey periods. 
13. Graph showing differences between original and replicate differential-grade global-positioning-system surveys of sandbar area, as percentage of original sandbar area, relative to sandbar size, lower Platte River, Nebraska, 2011.

14. Graphs showing quality-control data associated with spot measurements of sandbar height, lower Platte River, Nebraska, 2011: $(A)$ original versus replicate ranked spot measurements of sandbar height, and $(B)$ differences between ranked original and replicate spot measurements of sandbar height relative to sandbar

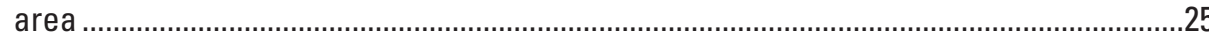

15. Graphs showing cumulative frequency distribution of sandbar topography, medians, and ranges of spot measurements of sandbar height using the rapid-assessment survey method, and medians and ranges of heights of previously used tern nests on four sandbars of varying size, lower Platte River, Nebraska, 2011: $(A)$ sandbar number 1, 3.4 acres; $(B)$ sandbar number 2, 8.7 acres; $(C)$ sandbar number 3 , 19 acres; and $(D)$ sandbar number $4,29.9$ acres

\section{Tables}

1. Ranges of daily discharge and stage range of Platte River at Louisville, Nebraska (USGS 06805500), during three survey periods, 2011

2. Number and total measured and estimated areas of emergent sandbars in the study segment of the lower Platte River, Nebraska, by bar type and survey period, 2011

3. Summary statistics of differences between measured median and maximum sandbar heights and results of Wilcoxon signed-rank comparison tests between survey periods at collocated sandbar pairs, lower Platte River, Nebraska, 2011

4. Summary of replicate surveys of sandbar area measured using differential-grade global-positioning system, lower Platte River, Nebraska, 2011

5. Differences between sandbar areas measured with differential-grade globalpositioning-system and using a total-station laser-surveying instrument, lower Platte River, Nebraska, 2011

6. Summary statistics of differences in measured sandbar height and results of Wilcoxon signed-rank comparison tests between replicate surveys using laserleveling method, lower Platte River, Nebraska, 2011 


\section{Conversion Factors and Datums}

\begin{tabular}{|c|c|c|}
\hline Multiply & By & To obtain \\
\hline \multicolumn{3}{|c|}{ Length } \\
\hline foot $(\mathrm{ft})$ & 0.3048 & meter $(\mathrm{m})$ \\
\hline mile (mi) & 1.609 & kilometer $(\mathrm{km})$ \\
\hline \multicolumn{3}{|c|}{ Area } \\
\hline acre & 4,047 & square meter $\left(\mathrm{m}^{2}\right)$ \\
\hline acre & 0.4047 & hectare (ha) \\
\hline acre & 0.4047 & square hectometer $\left(\mathrm{hm}^{2}\right)$ \\
\hline acre & 0.00405 & square kilometer $\left(\mathrm{km}^{2}\right)$ \\
\hline square mile $\left(\mathrm{mi}^{2}\right)$ & 2.590 & square kilometer $\left(\mathrm{km}^{2}\right)$ \\
\hline \multicolumn{3}{|c|}{ Velocity } \\
\hline mile per hour (mi/hr) & 0.44704 & meter per second $(\mathrm{m} / \mathrm{s})$ \\
\hline \multicolumn{3}{|c|}{ Flow rate } \\
\hline cubic foot per second $\left(\mathrm{ft}^{3} / \mathrm{s}\right)$ & 0.02832 & cubic meter per second $\left(\mathrm{m}^{3} / \mathrm{s}\right)$ \\
\hline \multicolumn{3}{|c|}{ Pressure } \\
\hline pound per cubic foot $\left(\mathrm{lb} / \mathrm{ft}^{3}\right)$ & 16.02 & kilogram per cubic meter $\left(\mathrm{kg} / \mathrm{m}^{3}\right)$ \\
\hline pound per foot-second (lb/ft-s) & 14.59 & $\begin{array}{l}\text { Newton per meter-second } \\
\quad(\mathrm{N} / \mathrm{m}-\mathrm{s})\end{array}$ \\
\hline
\end{tabular}

Altitude or vertical coordinate information is referenced to the National Geodetic Vertical Datum of 1929 (NGVD 29).

Altitude refers to distance above or below NGVD 29.

NGVD 29 can be converted to North American Vertical Datum of 1988 by using the National Geodetic Survey Conversion utility available at $h$ ttp://www.ngs.noaa.gov/TOOLS/Vertcon/ vertcon.html.

Horizontal coordinate information is referenced to the Nebraska State Plane-Feet, North American Datum of 1983 (NAD 83).

\section{Acknowledgments}

The authors thank Meghan Sittler, Lower Platte River Corridor Alliance (LPRCA) Coordinator, and all members of the LPRCA for their continued support of this project. Thanks also goes to the Nebraska Game and Parks Commission for allowing river reconnaissance camera deployment on their observation tower at Platte River State Park, and to the Lower Platte South Natural Resources District for allowing a temporary stage gage to be deployed on the Lied Bridge. 


\title{
Emergent Sandbar Dynamics in the Lower Platte River in Eastern Nebraska-Methods and Results of Pilot Study, 2011
}

\author{
By Jason S. Alexander, Devin M. Schultze, and Ronald B. Zelt
}

\section{Abstract}

The lower Platte River corridor provides important habitats for two State- and federally listed bird species: the interior least tern (terns; Sternula antillarum athallassos) and the piping plover (plovers; Charadrius melodus). However, many of the natural morphological and hydrological characteristics of the Platte River have been altered substantially by water development, channelization, hydropower operations, and invasive vegetation encroachment, which have decreased the abundance of high-quality nesting and foraging habitat for terns and plovers. The lower Platte River (LPR), defined as 103 miles (mi) of the Platte River between its confluence with the Loup River and its confluence with the Missouri River, has narrowed since the late-19th and early-20th centuries, yet it partially retains many geomorphologic and hydrologic characteristics important to terns and plovers. These birds nest on the sandbars in the river and along shorelines at sand- and gravel-pit lakes in the adjacent valley.

The need to balance continued economic, infrastructure, and resource development with the conservation of important physical and aquatic habitat resources requires increased understanding of the physical and biological dynamics of the lower Platte River. Spatially and temporally rich datasets for emergent sandbar habitats are necessary to quantify emergent sandbar dynamics relative to hypothesized controls and stressors. In cooperation with the Lower Platte South Natural Resources District, the U.S. Geological Survey initiated a pilot study of emergent sandbar dynamics along a 22-mi segment of the LPR downstream from its confluence with Salt Creek, near Ashland, Nebraska. The purposes of the study were to: (1) develop methods to rapidly assess sandbar geometries and locations in a wide, sand-bed river, and (2) apply and validate the method to assess emergent sandbar dynamics over three seasons in 2011. An examination of the height of sandbars relative to the local stage of the formative discharge event, and how subsequent river discharges, of both high and low magnitude, alter sandbar geometries and abundance within the LPR was of particular interest.
A "rapid-assessment" method was developed with the goal of characterizing the spatial distribution and habitatrelevant geometries of the complete population of sandbars along the study segment. Three primary measures were used to assess emergent sandbar dynamics in the study segment: sandbar area, sandbar height, and sandbar location. Data to derive these measures were collected during three, week-long survey periods in 2011, herein named "spring survey period," "summer survey period," and "fall survey period." Emergent sandbars were grouped into one of three generalized types: (1) bank-attached, (2) island-attached, and (3) mid-channel.

The area of 68 sandbars, with a total estimated emergent area of 360 acres, was surveyed or estimated during the spring survey period. A total of 105 sandbars, with total estimated emergent area of 315 acres, were surveyed or estimated during the summer survey period. Seventy-three sandbars, with a total estimated emergent area of 402 acres, were measured during the fall survey period. There were 17 collocated sandbars common to the spring and summer survey periods, 27 collocated sandbars common to summer and fall survey periods, and 21 collocated sandbars common to spring and fall survey periods.

Changes in sandbar area between seasonal survey periods, when measured for collocated sandbar pairs, were similar to the seasonal differences observed for the larger population of sandbars. Mid-channel sandbar pairs had a median decrease in emergent area of 4.3 acres between spring and summer survey periods. Bank-attached sandbar pairs had the widest range of areal change between spring and summer, with most bars eroding, but some bars undergoing net expansion of up to 1.9 acres.

A comparison among survey periods of cumulative frequency distributions of measured sandbar heights indicated that the high platform of sandbars was higher during the spring survey period than during the subsequent summer and fall survey periods. Median sandbar height, indexed to the stage of 4,000 cubic feet per second, decreased from about 4.5 to 3.0 feet ( $\mathrm{ft}$ ) between the spring and summer survey periods. Sandbar heights tended to follow a wavy, longitudinal pattern whereby certain reaches of the study segment consistently had more abundant and higher sandbars, and others had fewer, 
lower sandbars. Large sandbars tended to be more abundant and higher between State Highway 50 and near Cedar Creek, and lower and less abundant in the first $3 \mathrm{mi}$ upstream from State Highway 50.

The high platform on sandbars was between 0.5 and $2.0 \mathrm{ft}$ higher during the spring survey period than for the subsequent summer and fall survey periods. Bank-attached and mid-channel sandbars generally had the highest group-median height and group-median of maximum height across all seasons. Group-median heights for all sandbar types measured during the spring survey period indicated that the high platform of most sandbars was about 2-3 ft lower than the estimated stage of the 2010 peak discharge of 136,000 cubic feet per second. Maximum measured sandbar heights from the spring survey generally were higher than the estimated stages of the 2011 peak discharge, indicating that at least small parts of many sandbars were not inundated.

Comparisons among seasonal survey periods of ranked differences between collocated sandbar pairs further confirm that a lowering of sandbar heights followed the spring survey period. Median differences in sandbar median and maximum heights between the spring and summer survey periods indicated decreases of 0.83 and $0.81 \mathrm{ft}$, respectively, for collocated sandbar pairs. Median differences among collocated pairs in sandbar median and maximum heights between the summer and fall survey periods indicated a decrease of $0.09 \mathrm{ft}$ for each statistic.

One of the primary motivations of the study was to characterize the height of sandbars relative to the stage of formative flows. Sandbar heights surveyed during the spring survey period indicated that the high platform of sandbars can be close to the maximum stage of formative flow events, but this height is rare, and more often the highest part of sandbars is $1-2 \mathrm{ft}$ less than the formative stage. Although the methods used for the study differ from previous studies in the LPR, the estimates of bar heights are consistent with previous studies, which, based on estimations made for this report, indicated sandbars formed between 0.9 and $4.2 \mathrm{ft}$ lower than their respective formative stages.

The streamwise distribution of the emergent sandbar area did not change substantially among the three survey periods. Between spring and fall survey periods, the median change in the fraction of total emergent sandbar area, tabulated by river mile, was a decrease of only 0.21 percentage point, and the interquartile range of such net changes was from -1.32 to 1.06 percentage points.

Replicate differential-grade global-positioning system (DGPS) surveys of the sandbar area were performed on a total of 13 sandbars across much of the range of sandbar sizes present during the survey periods, and the mean relative difference in sandbar area between original and replicate DGPS measurements was 0.62 percent with all replicate measurements within 5 percent of the original survey. Results from signedrank comparisons of replicate pairs indicated that differences in area were not significant. Paired measurements of sandbar area made with a total-station system and the DGPS method indicated that sandbar areas obtained using the DGPS method likely are within 5 percent of those obtained using higherprecision methods.

Replicate surveys of sandbar heights using the rapidassessment method indicated that differences in measured sandbar heights were not significant, averaged $-0.002 \mathrm{ft}$, and ranged from -1.15 to $0.48 \mathrm{ft}$ for spot heights. Measured sandbar heights and tern and plover nest heights were compared with the cumulative frequency distribution of bar heights from detailed measurements using total-station surveys. Results indicated that bar-height values greater than the median height from the rapid-assessment survey method adequately represented the range of nest heights observed in 2011. With continued monitoring of sandbar dynamics, the hydrogeomorphic characteristics of areas of the LPR that consistently produce habitat favored by nesting colonies of terns and plovers potentially can be quantified and identified. Such analyses would be valuable for planning and permitting of future river corridor development, infrastructure, and construction, as well as for constructing or restoring persistent and successful tern and plover habitats in sand-bed rivers elsewhere on the Great Plains.

\section{Introduction}

The lower Platte River (LPR) corridor provides important habitats for two State- and federally listed bird species: the interior least tern (terns; Sternula antillarum athallassos) and the piping plover (plovers; Charadrius melodus). However, many of the natural morphological and hydrological characteristics of the Platte River have been altered substantially by water development, channelization, hydropower operations, and encroachment into the channel by vegetation (Williams, 1978; Eschner and others, 1983; Johnson, 1994; National Research Council, 2005; Ginting and Zelt, 2008). These alterations have resulted in a decrease of nesting and foraging habitat suitable for terns and plovers through channel narrowing and decreased area of barren, emergent (above the water surface) mid-channel sandbars (National Research Council, 2005). Terns and plovers nest annually on the sandbars in the river and along shorelines of the active and abandoned openpit sand- and gravel-mine lakes on the adjacent valley floor.

The LPR, defined here as the 103-mile (mi) segment of the Platte River between its confluence with the Loup River and its confluence with the Missouri River (fig. 1), has narrowed since the late-19th and early-20th centuries (Joeckel and Henebry, 2008), yet it partially retains many of the geomorphologic and hydrologic characteristics important to terns and plovers. The LPR corridor, the land region encompassing the LPR channel, floodplain, valley floor, and valley walls, is situated within the most populous counties of Nebraska. The valley floor of the LPR also is home to numerous farms, aggregate extraction operations, waterfront developments, and state parks, and is crossed by several railroads, state and interstate highways, and water courses. The LPR alluvial aquifer 


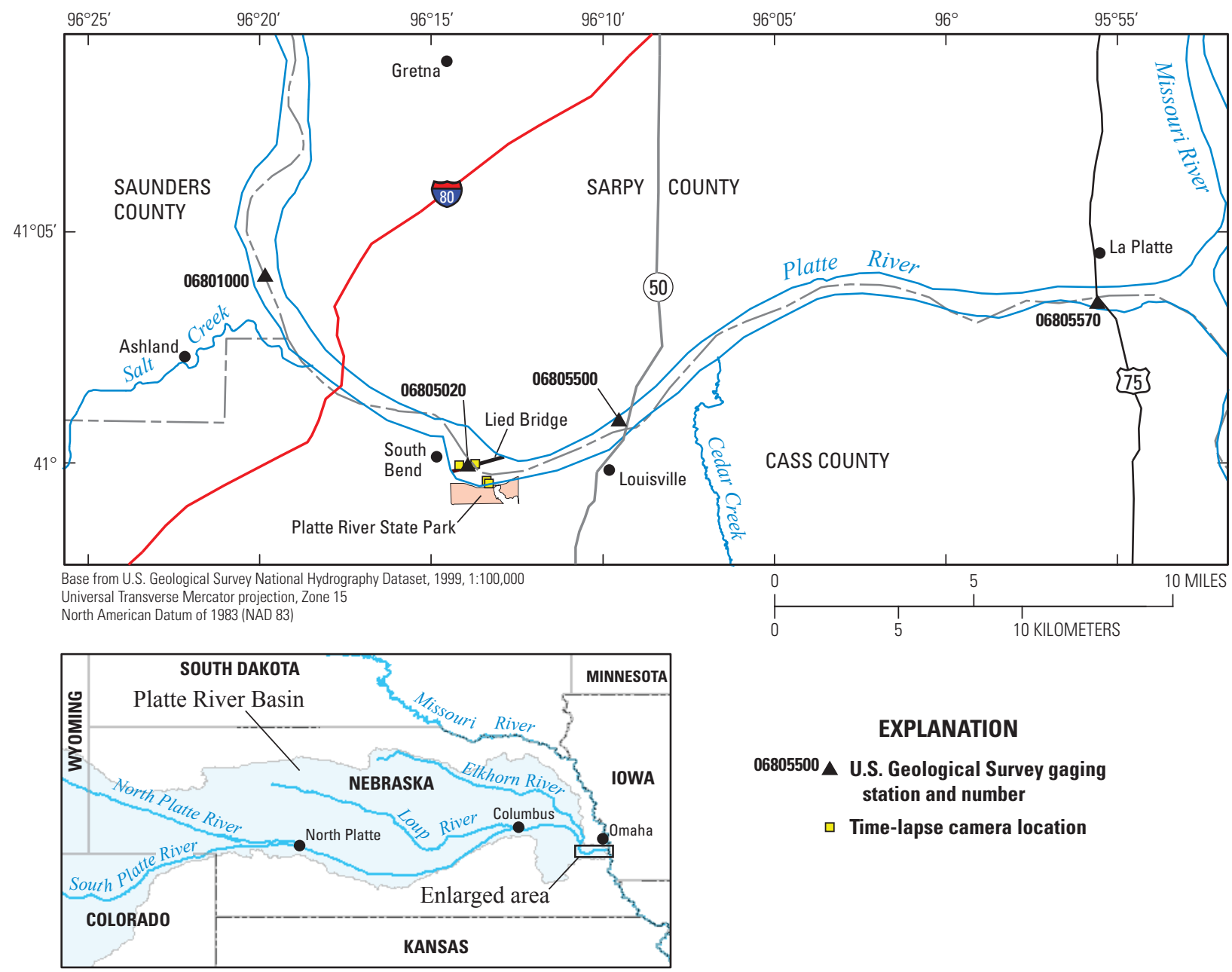

Figure 1. Location of lower Platte River study area, U.S. Geological Survey gaging stations, and reconnaissance timelapse cameras, Nebraska.

is a primary source of drinking water for nearby cities and towns, including the two most populous cities of Nebraska: Omaha and Lincoln.

Balancing continued economic, infrastructure, and resource development with the conservation of important physical and aquatic habitat resources requires increased understanding of the physical and biological dynamics of the LPR. An understanding of the interactions of hypothesized natural controls (streamflow, sediment supply, river morphology, and ice effects) with anthropogenic stressors (bridges, hydropower operations, bank protection, and levees), and how these interactions may affect the locations, abundance, quality, and persistence of emergent sandbar habitats important to State- and federally listed species, is of particular concern to local stakeholders. To approach this complex problem, spatially and temporally rich datasets for emergent sandbar habitats are necessary to begin to quantify emergent sandbar dynamics relative to hypothesized controls and stressors. Terns and plovers use emergent sandbar habitats in other river systems across the Great Plains, and substantial efforts are being made nationally to restore habitats in rivers where dams and other river engineering have degraded the quality of sandbar habitat (U.S. Army Corps of Engineers, 2011; Lott and Willey, 2012). Thus, an understanding of emergent sandbar dynamics in the LPR also helps inform restoration and preservation of emergent sandbar habitats in the region. The term "sandbar dynamics" is used in this report to refer to the temporal changes in the number, geometry, and spatial distribution of emergent sandbars within a river channel and as related to controlling factors.

In cooperation with the Lower Platte South Natural Resources District (LPSNRD), the U.S. Geological Survey (USGS) initiated a pilot study (hereinafter referred to as "the study") of emergent sandbar dynamics along a 22-mi segment of the LPR. The purposes of the study were to (1) develop methods to rapidly assess sandbar geometries and locations in a wide, sand-bed river, and (2) apply and validate the method to assess emergent sandbar dynamics over three seasons within a calendar year. An examination of the height of 
sandbars relative to the local stage of the formative discharge event, and how subsequent river discharges, of both large and small magnitude, alter sandbar geometries and abundance within the LPR, was of particular interest.

\section{Purpose and Scope}

The purpose of this report is to describe the methods developed and used to collect data associated with emergent sandbars (hereinafter called "sandbars"), as well as the findings of the initial analyses of these data, for the 22-mi segment of the LPR downstream from its confluence with Salt Creek, near Ashland, Nebraska (hereinafter referred to as the "study segment") (fig. 1). These data include surveyed geometries and spatial distribution of sandbars within the study segment during three data-collection periods, each associated with a typical open-water (no ice cover) season. Analyses include seasonal comparison of metrics of sandbar geometry, statistical analysis of seasonal paired geometries, calculation and presentation of metrics of sandbar spatial distributions, and statistical analysis and presentation of quality-control measures. Additional assessments of data quality are described in appendixes 1 and 2. The term "sandbar geometry" in this report refers to the planimetric area and characteristic height (height indexed to some datum) of individual sandbars. The term "reach" in this report refers to lengths of river, greater than 1 average channel width in length, but shorter than the study segment itself. The lowest $4 \mathrm{mi}$ of the Platte River were not included in the study because the hydraulics in that segment are controlled intermittently by backwater effects from the Missouri River.

\section{Physical and Hydrologic Setting}

The Platte River Basin has its headwaters on the eastern slope of the Rocky Mountain region of Colorado and Wyoming, and traverses the Great Plains and Dissected Till Plains of Nebraska, draining about 86,000 square miles $\left(\mathrm{mi}^{2}\right)$ along its course (Fenneman, 1928; Eschner and others, 1983)

(fig. 1). The Platte River in eastern Nebraska flows through a broad valley that progressively narrows as it extends downstream, funneling into the Missouri River near La Platte, Nebraska (Elliott and others, 2009). The valley bottom of the Platte River in the 22-mi study area is bounded by the sedimentary bedrock bluffs of the eastern Platte River Gorge (Joeckel and Henebry, 2008), and the river here has less variation in channel width, greater sinuosity, and deeper flow than in its upstream segments bounded by its confluences with the Loup and Elkhorn Rivers and Salt Creek (Ginting and others, 2008; Elliott and others, 2009). The slope of the Platte River in the study area averages 0.075 percent, the lowest grade of any segment of the Platte River in Nebraska (Bentall, 1991).

The flow of the LPR is dependent on the flows in several primary tributaries: the Loup River, which has a confluence with the LPR near Columbus; the Elkhorn River, which has a confluence with the LPR near Gretna; and, to a lesser extent, on flows in Salt Creek, a smaller tributary, which has a confluence with the LPR near Ashland (Bentall and Shaffer, 1979; Ginting and others, 2008) (fig. 1). Streamflows in the Loup and Elkhorn Rivers are substantially affected by groundwater seepage, which provides a steady base flow to the LPR even during dry periods (Bentall and Shaffer, 1979). Because neither of these tributaries has a large, main-channel floodcontrol dam or reservoir, general hydrologic measures - particularly the mean annual discharge and instantaneous annual maximum discharge - have been less affected in the LPR than those in the Platte River upstream from its confluence with the Loup River (Eschner and others, 1983; Ginting and Zelt, 2008; Dietsch and others, 2009). Like other major trunk streams flowing over the Great Plains and with headwaters in the Rocky Mountains, the LPR typically has two annual rises: a rise associated with Great Plains snowmelt and the breakup of river ice cover, and a rise associated with snowmelt in the mountains and spring rainfall on the plains. Streamflows in the LPR also tend to increase because of runoff associated with regional outbreaks of summer thunderstorms, and these increases often inundate sandbars and associated resident tern and plover nests (Parham, 2007; Brown and Jorgensen, 2008; Brown and others, 2011a).

Although generalized flow measures in the LPR have been less affected by water development than in upstream segments (Ginting and Zelt, 2008), the intra-daily flows throughout the LPR are characterized by a ubiquitous diel wave that typically cycles over a 24 -hour period. The wave cycle is the result of hydrocycling from power generation at a hydroelectric facility near Columbus, Nebraska (Loup River Public Power District, 2008). Power generation occurs generally during peak-demand periods, and the facility can release a maximum flow of 3,500 cubic feet per second $\left(\mathrm{ft}^{3} / \mathrm{s}\right)$; however, in combination with naturally occurring changes in flow magnitude, maximum diel flow range may be larger. The amplitude of the wave gradually attenuates downstream, but commonly results in stage changes of at least 0.4 feet (ft) over a 24-hour period in the study segment. The confluence of the tailrace (released-water return flow) of the hydroelectric facility and the LPR is about $2 \mathrm{mi}$ downstream from the confluence of the Loup River and the LPR, and the hydrocycle wave is apparent at all streamflow-gaging stations along the LPR downstream from the tailrace. Although some natural diel fluctuation in river levels probably occurred prior to the beginning of operations at the hydroelectric facility in 1937, large fluctuations in river stage over the course of a single day, in the absence of intense rainfall or snowmelt, are not apparent from the typical daily hydrograph of streamflow-gaging stations on any of the primary tributaries to the LPR. Therefore, the magnitude of the fluctuations in daily discharge and stage measured in the LPR during the study was likely greater than the magnitudes that would have been observed prior to the hydroelectric facility. 


\section{Definitions and Descriptions of Sandbars in the Lower Platte River}

The Platte River in Nebraska is a wide, sand-bedded, braided river. The term "braided" in this report is used as a general term to describe the division of water flow in a river channel into two or more primary threads by islands or emergent sandbars. In the case of large (loosely defined here as being about one average channel width or more in length), densely vegetated islands, braiding is commonly not discharge-dependent because these features generally cause flow division for discharge magnitudes up to or near bankfull. This type of braiding is usually referred to "anabranching" if the island is very large and flow division extends for several tens of channel widths or more (Bridge, 2003); anabranches presently occur in the LPR only upstream from the study area. For more transient features, such as sandbars, braiding is discharge-dependent because discharges less than bankfull often cause the submergence of these features in the LPR (Parham, 2007).

One of the primary characteristics of braided rivers is the presence of macroforms, which are large, transient, sedimentary deposits, often referred to as "bars" or, with inferred grain size, "sandbars." The term "sandbar" is used in this report to refer to the macroforms of the LPR described in detail by Smith (1970, 1971), Blodgett and Stanley (1980), and Crowley (1983), and similar types of deposits described in rivers elsewhere (see Bridge [2003] for general review of macroforms). More specifically, the sandbars described in this report were all emergent above the water surface at the time of observation. Sandbars differ from other bedforms such as dunes and ripples because their length is proportional to channel width, and their height is proportional to the depth of the river during their formation. In the Platte River system in Nebraska, sandbars typically are "transverse"- that is, the downstream slip face of the bar is aligned obliquely or nearly perpendicular to the primary flow direction during bankfull discharges (Crowley, 1983), although their shape may change substantially after flow recession. Smith (1971) described transverse sandbars as the "most characteristic and important bedforms in the lower Platte River. They comprise a varied group of tabular, essentially flat-topped, periodic or solitary sand bodies which grow by down current additions to slip faces." However, Smith (1971) also concluded that most exposed sandbars, especially large sandbars that cause braiding in the LPR during low discharges, are not simply exposed transverse bars, but depositional features that initiate as transverse bars during high flows and evolve (through changes in texture, shape, and size) after flow recession during periods of moderate-to-low discharges.

Because of the difficulty of directly observing their formation, quantitative observations of the hydraulics and sediment-transport fields around Platte River-type macroforms have not been well-described (Leeder, 1999; Best and Rhoads, 2008), and tools to predict the location, conditions of formation, and geometry of these macroforms still are limited to field, flume, and numerical modeling descriptions. Smith
(1971) attributed the formation of sandbars in the LPR at "low and intermediate discharges" to be the result of variations in depth and velocity over short distances, whereby sediment was deposited on the riverbed in locations where the tractive forces of the bed were locally reduced enough to stall sediment transport, similar to the mechanism of riffle formation proposed by Leopold and Wolman (1957). At high discharges, Smith (1971) attributed bar formation in the LPR to the coalescing of diffuse dune fields during the recession of a flood, and showed that, once formed, water-surface slope over the bars was substantially steeper than in other areas of the river channel, often forming "sand riffles." Similar anecdotal observations of large sandbars emerging after flow recession in areas of the LPR, where sand riffles were present during high flows, have been made by the authors.

\section{Previous Studies}

The surfaces of mid-channel sandbars are the primary onriver nesting habitat feature for terns and plovers in the LPR. Previous authors have described and classified macroforms in the LPR (Crowley, 1983), have investigated their internal stratigraphy and sedimentology (Ore, 1964; Smith, 1970; Blodgett and Stanley, 1980; Crowley, 1983), and have described observations of their formation and evolution (Smith, 1971; Blodgett and Stanley, 1980; Crowley, 1983). However, because of sandbar importance as nesting habitat for bird species, recent work has focused on the physical characteristics of sandbars and surrounding channel morphology associated with the nesting of species of concern. This work has focused particularly on measuring the area of sandbars and the height above the stage of index discharges because these metrics provide insight into potential diagnostic differences between sites selected by terns and plovers and sandbars without observed nesting. Some recent nesting-related work also has described associated nearby channel morphologic characteristics. For example, Kirsch (1996) indicated that, although gross availability of sandbar habitat was not limiting on the LPR, terns nested on mid-channel sandbars where channel width tended to be greater than at sites without nests. More recent investigations also have indicated positive relations between nearby non-vegetated river channel width and the presence of tern and plover nesting sites (Elliott, 2011; Jorgensen and others, 2012).

Using a combination of remote sensing and groundlevel surveys, Ziewitz and others (1992) characterized sandbar geometry and nest presence or absence at potential nesting sites along a 3-mi systematic sampling interval in the LPR in 1988. Sandbar area was calculated from aerial photographs taken during aerial surveys of birds. Mean and maximum sandbar height relative to the water surface were estimated from on-the-ground transect surveys, and indexed to a discharge of $4,000 \mathrm{ft}^{3} / \mathrm{s}$ by estimating water travel time between bounding streamflow-gaging stations. Along the most downstream 54 mi of the LPR, Brown and Jorgensen (2008) 
surveyed sandbar heights for bars larger than 0.5 acres along a 1/3-mi systematic interval, and referenced heights to the daily maximum and minimum stages at nearby gaging stations. They reported that bar height progressively increased in the downstream direction. Brown and Jorgensen (2009) used similar methods to measure the height and area of sandbars along most of the 103-mi segment of the LPR. They measured the height and area of 36 sandbars: 26 with nests and 10 without nests. Sandbar height was indexed to the long-term mean stage for June 15 at the nearest representative streamflowgaging station. The index stages used by Brown and Jorgensen (2009) represented a discharge ranging from about 6,200 to $12,000 \mathrm{ft}^{3} / \mathrm{s}$ on the latest stage-discharge rating tables for the gaging stations along the length of the LPR (M.J. Andersen, U.S. Geological Survey, written commun., 2011). For the Platte River streamflow-gaging stations referenced in this study, near Ashland (USGS 06801000) and at Louisville (USGS 06805500), the stages used by Brown and Jorgensen (2009) to index bar heights were equivalent to flows of about 11,100 and 12,000 ft $3 / \mathrm{s}$, respectively. Brown and Jorgensen (2009) again indicated that sandbar heights progressively increased in the downstream direction, but the rate of downstream increase was substantially higher in the segment of the LPR downstream from the Elkhorn River.

\section{Approach and Methods}

Previous studies of sandbar geometry have indicated substantial spatial variation including spatial trends in sandbar geometry in the LPR (Brown and Jorgensen, 2008, 2009). To capture both the seasonal and spatial variation in sandbar locations and geometries in the LPR, a "rapid-assessment" method was developed and used for the study, with the goal of characterizing the spatial distribution and habitat-relevant geometries of the complete population of sandbars along the 22-mi study segment. These geometries and distributions are represented by data collected during week-long survey periods within the three open-river seasons during calendar year 2011. The rapid-assessment method was used instead of selecting shorter, fixed study reaches or systematic intervals because a primary goal of the study was to understand if the spatial distribution and geometries of bars changed substantially from season to season, and this required a more spatially enriched dataset.

\section{Hydrologic Context}

Previous studies have indicated that less frequent, highmagnitude discharges are a fundamental process for the formation of large, higher sandbars that are used most frequently for nesting by terns and plovers in the LPR (Parham, 2007). Models presented in previous work have assumed that sandbar geometries persist until at least the peak flow in the year following initial formation (Parham, 2007). Moreover, more recent work indicates that nesting has occurred on sandbars that are in about the same location during as much as a 3-year period (Brown and Jorgensen, 2010). Unless otherwise noted, descriptions of streamflow discharges on the Platte River are referenced to the hydrologic record at the streamflow-gaging station on the Platte River at Louisville, Nebraska (hereinafter, the "Louisville gage"), which is the only gaging station on the Platte River downstream from Salt Creek that has a currently applicable rating of the stage-discharge relation (U.S. Geological Survey, 2012).

The data-collection activities described in this report spanned three survey periods of 7 days or less, during three open-water (no ice) seasons in the LPR in calendar year 2011 (fig. 2). Sandbar geometries and locations during the first survey period, April 6-12, 2011, likely were a reflection of the collective processes of flooding, low flows, and winter ice effects and ice melt in the year that preceded the survey. In particular, the instantaneous peak discharge during water year 2010 of 136,000 ft 3 s (U.S. Geological Survey, 2011), the third highest instantaneous discharge since the Louisville gage began recording in 1953, likely had a great effect on the arrangement and geometries of sandbars in the study area. Streamflows in the LPR during the three 2011 survey periods were commonly greater than the daily averages for the period of record (fig. 2). During late June, July, and August 2011, streamflow often ranked above the 90th percentile of daily flow values for the date (streamflows that, for each calendar date, were exceeded less than 10 percent of the time during the 1953-2011 period of record). The higher summer base flows in the LPR during 2011 resulted from the very wet conditions in the upper Platte River Basin (Grigg and others, 2012), which required sustained releases from water-supply reservoirs to accommodate runoff into the late summer. Although base flows were higher than average during water year 2011, the annual maximum discharge of about $45,400 \mathrm{ft}^{3} / \mathrm{s}$ ranks near the median ( 33 out of 59) of annual maximum discharges within the period of record for the Louisville gage.

River stages in the LPR within the study segment sometimes are controlled by factors other than the streamflow of the Platte River. River stages in the most downstream segments of the LPR also are controlled by the stage of the Missouri River, which acts as a downstream altitude control on the water surface. The hydraulic control of the stage of a river by a higher stage in a downstream water body is referred to as a "backwater effect" because the body with the highest stage will "block" flow in a tributary river, causing a rise in its stage (Meade and others, 1991); consequently, the tributary river may have an unusually high stage at a low-magnitude discharge.

A complete analysis of the hydraulic extent and effects of backwater from the Missouri River was beyond the scope of the study; however, an attempt was made to estimate the upstream extent of backwater altitude on the LPR. For the purposes of the study, the altitude of backwater extent on the LPR was defined as the interpolated altitude of the National Weather Service (NWS) flood stage of the Missouri River. This altitude was considered a conservative estimate of the 


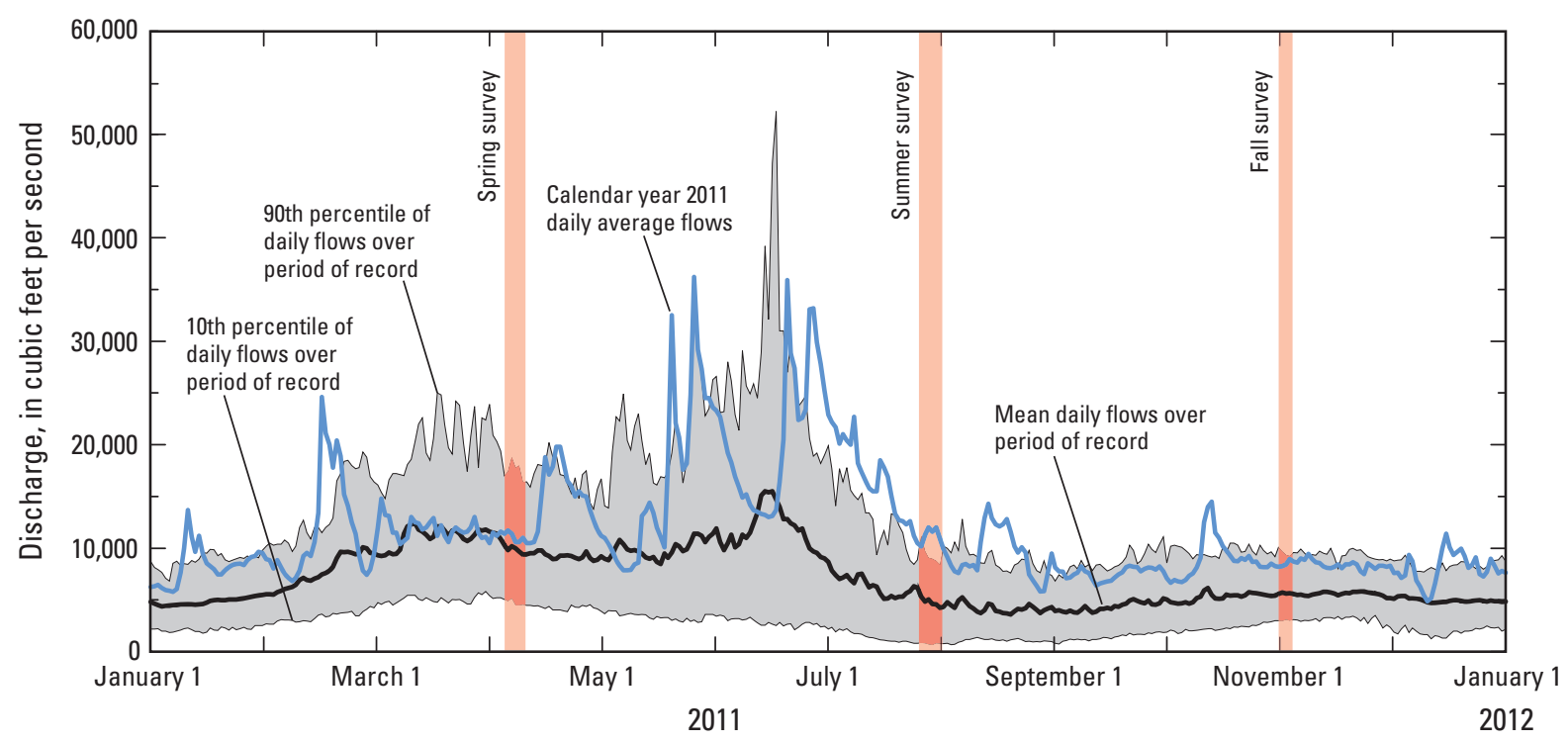

Figure 2. Daily average discharge in calendar year 2011 and selected daily discharge statistics for Platte River at Louisville, Nebraska. Daily statistics selected were the 90th percentile, the mean, and the 10th percentile of daily mean discharges, by calendar date, during the 1954-2011 period of record.

potential extent of backwater effects from the Missouri River that may have a considerable effect on sandbar depositional and erosional processes and associated geometries. The altitude of the flood stage of the Missouri River at its confluence with the Platte River was estimated by first digitizing the centerline distance of the Missouri River channel between the two streamflow-gaging stations that bound the Missouri River-Platte River confluence; the Missouri River at Omaha, Nebraska (USGS station 06610000); and the Missouri River at Nebraska City, Nebraska (USGS station 06807000). Second, the slope of the Missouri River channel centerline at flood stage was calculated using the difference between the flood stage at each gage (referenced to the National Geodetic Survey 1929 datum), divided by the river distance from step 1. Third, the altitude of the flood stage of the Missouri River at the Platte River confluence was linearly interpolated along the slope of the centerline of the Missouri River. Finally, the estimated altitude of the flood stage of the Missouri River was interpolated upstream on the Platte River and compared with the altitude contours of the USGS 7.5-minute quadrangle (U.S. Geological Survey, 2010).

The estimated plane of the Missouri River flood stage (conservative estimate of backwater-effects limit) intersects the LPR at a little more than $3.5 \mathrm{mi}$ upstream from the Missouri River, but was rounded up to $4 \mathrm{mi}$ to accommodate estimation uncertainty and the expected effect of the backwater on deposition immediately upstream. The estimated upstream extent of Missouri River backwater effects was the basis for fixing the downstream end of the study area because it was assumed that sandbar geometries within the backwateraffected zone were governed primarily by backwater-affected river hydraulics, rather than by hydrologic and geomorphic processes driven by the LPR watershed.

\section{Field Data Collection and Analysis}

Three primary measures were used to assess emergent sandbar dynamics in the study segment: sandbar area, sandbar height, and sandbar location. Data to derive measures of sandbar dynamics were collected during three, week-long survey periods in calendar year 2011. The first survey was conducted during April 6-12, hereinafter referred to as the "spring survey." The second survey was conducted during July 26-August 2, hereinafter referred to as the "summer survey." The third survey was conducted during October 31-November 4 , hereinafter referred to as the "fall survey." The measures of sandbar dynamics presented in this report are not interpreted as having sharply defined, singular values. Rather, these measures are approximations of each metric's magnitude as they existed in the LPR during the three survey periods. Field data collection focused only on sandbars that were mostly barren. However, some sandbars, particularly during the summer survey, had dispersed bunchgrasses and forbes, or patches of more dense, but immature vegetation (defined here as growth that was judged to have occurred since recession of spring high flows). In all cases, total vegetative cover was less than 50 percent, and in most cases much less than 50 percent.

Emergent sandbars were grouped into one of three generalized types: (1) bank-attached, (2) island-attached, and (3) mid-channel. At the discharge and stage observed, bank-attached and island-attached sandbars had a direct, dry connection to a river bank or island, respectively, whereas mid-channel sandbars were separated from the river banks and islands by a wetted channel. Sandbars attached to the river banks or islands are used less frequently by terns and plovers, possibly because mid-channel nesting habitat is less accessible to predators (Joel Jorgensen, Non-Game Bird Manager, Nebraska Game and Parks Commission, oral commun., 2011; 
U.S. Army Corps of Engineers, 2011; Lott and Wiley, 2012). Although mid-channel sandbars could be considered attached to river banks or islands at lower discharges, there is no practical way to quantitatively assess this attachment over a range of river stages in the absence of detailed topographic and bathymetric surveys.

\section{Sandbar Number and Area}

The area of emergent sandbars was surveyed during the study to characterize the size distribution and to provide summary measures for the relative sizes of sandbars in the LPR during the study period. Changes in the discharge of the river and associated changes in river stage may have a substantial effect on the area of a sandbar that is emergent above the water surface, particularly if a large part of the sandbar is lowlying. Furthermore, in the absence of comprehensive surveys of the emergent and submerged topography of the sandbars, there is no practical method to normalize the area of emergent sandbars to an index stage or discharge. Therefore, survey periods representative of each season of interest were selected; however, some scheduling flexibility was needed to maximize surveying during periods of discharge with relative stability and similarity, so that sandbar areas were most comparable within and across the three survey periods.

\section{Field Data Collection}

Sandbar areas were surveyed in two different ways, depending on the field-estimated size of the sandbar. A coarser method to survey sandbar area and location was used for sandbars with an estimated area of less than 2 acres, and a finer method was used for sandbars with estimated area of 2 acres or more. Two acres was selected as the threshold value between survey methods because previous field surveys of sandbars with colonies of terns and plovers indicated that most nests generally were observed on sandbars larger than 2 acres (Joel Jorgensen, Nebraska Game and Parks Commission, oral commun., 2011). Sandbar areas were estimated in the field using a laser rangefinder capable of measuring the length and width of each sandbar from a distance. If the length-width product was less than 2 acres, the sandbar was grouped into one of four size bins: area $<0.5$ acres, $0.5-<1.0$ acres, $1.0-<1.5$ acres, and $1.5-<2.0$ acres.

Sandbars with an estimated area of more than 2 acres were surveyed using a handheld, 14-channel, differentialgrade global-positioning system (DGPS) receiver. When operating in DGPS mode, the receiver was capable of achieving real-time sub-meter accuracy using any available satellitebased augmentation system (Ashtech LLC, 2010). The Federal Aviation Administration's Wide-Area Augmentation System (WAAS) was the only non-commercial system available within the study area, and the receiver was capable of operating in DGPS mode at all times because of the wide horizons of the LPR. All survey waypoints were georeferenced in the Nebraska State-Plane coordinate system, based on the North
American Datum of 1983 (NAD 83). Sandbar areas were surveyed by an operator holding the DGPS receiver, and walking the rim of the "dry crest" of each sandbar, logging positional waypoints every $10 \mathrm{ft}$. The "dry crest" was defined as the part of the sandbar emergent above the diel high-water mark from daily stage fluctuations (fig. 3). The dry crest was used to normalize measurements among sandbars to the daily high stage, which was relatively constant within each survey period, but differed somewhat between survey periods (table 1). The dry crest is identifiable in the field by a scalloped face along the margin of the sandbar that separates drier sand from saturated or wave-sculpted sand, and the rim of the dry crest was the area defined as "emergent" for the study.

\section{Data Analysis}

Points logged along the margin of each sandbar were post-processed in a geographic information system (GIS) to remove redundant points from clusters or points recorded unintentionally by the operator. After post-processing, the points were used to create digital polygons and to make calculations of sandbar dry-crest areas using the GIS. In several cases, sandbars were composed of complexes of smaller sandbars separated from a larger "core" sandbar by shallow cross-bar channels (fig. 3C). In such cases, the dry crests of all individual sandbars were logged and attributed with codes to associate them with the larger core sandbar. Thus, the sandbar area for sandbar complexes was considered the total dry-crest area of the core sandbar and smaller sandbars surrounding the core.

Assessment of seasonal changes in emergent sandbar quantity and area was done in three primary ways. First, an assessment of the total number of bars and the total estimated emergent sandbar area for each survey period was performed. The total emergent sandbar area was calculated for each survey period by summing the total area of emergent sandbars measured using DGPS and the estimated area of individual sandbars smaller than 2 acres. For sandbars smaller than 2 acres, areas were estimated by assigning the midpoint of the 0.5 -acre bin size to all bars within each size bin. For example, for all bars within the size bin "area less than 0.5 acres," each bar was assumed to be 0.25 acres in area. Next, an assessment of changes in sandbar area by sandbar type was done for all sandbars where DGPS measurements were made. Because this assessment was focused on those sandbars generally larger than 2 acres, changes were quantified by comparison of basic summary statistics (mean, median, interquartile range) for all sandbar types by survey season. Finally, to assess processbased changes by survey season, an assessment of changes among individual, collocated sandbar pairs and by sandbar type was performed. Collocated sandbar pairs were identified by intersecting sandbar polygons from each survey period in the GIS. If two polygons intersected, regardless of how much area overlapped between the two, the sandbars were considered a non-independent pair and included in the test data. Changes were assessed as the difference between measured 


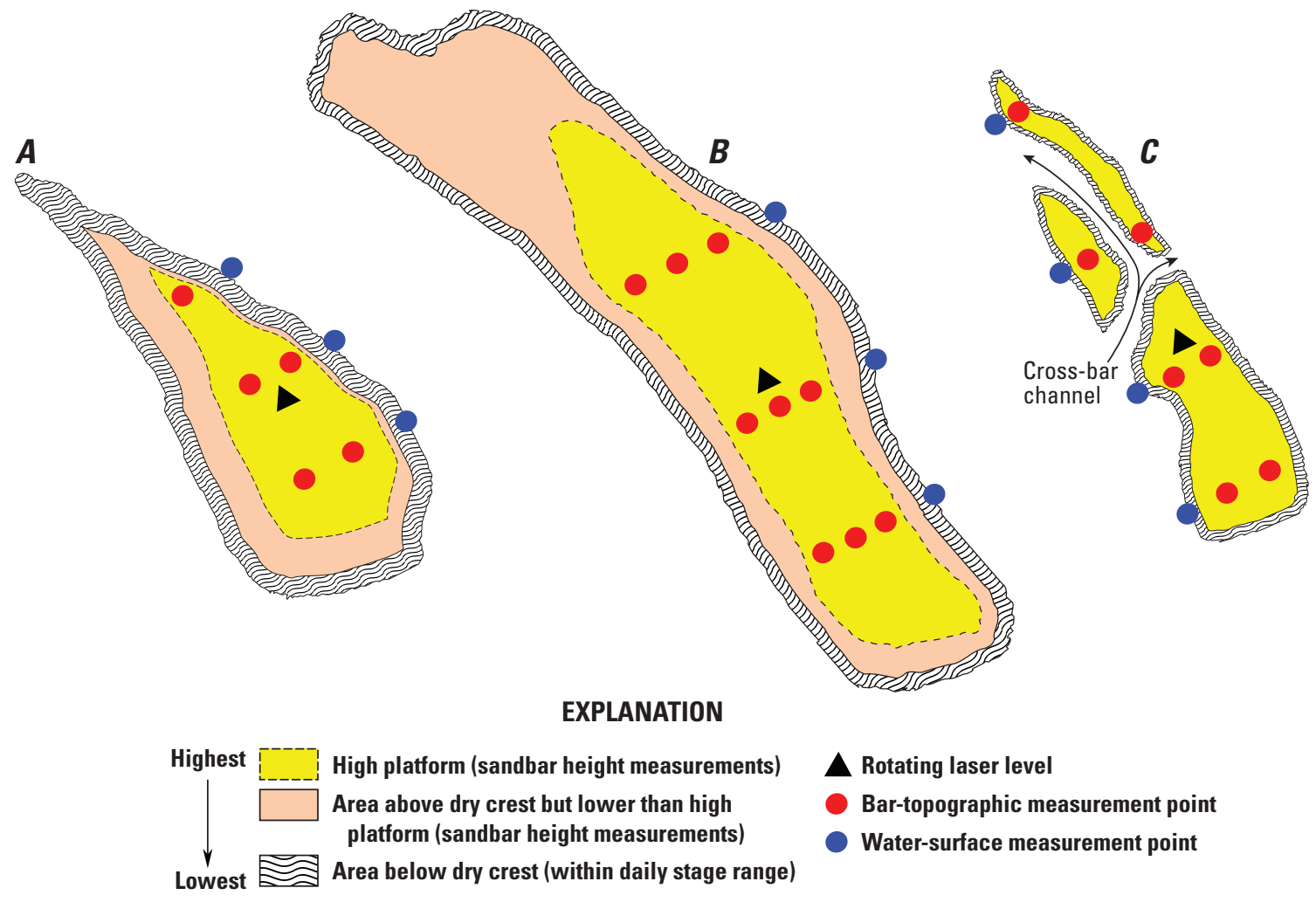

Figure 3. Typical levels and shapes of emergent sandbars in lower Platte River, Nebraska, and associated point spacing methods for surveying sandbar height: $(A)$ streamwise tapering, $(B)$ rectangular, and $(C)$ dissected and tapering.

Table 1. Ranges of daily discharge and stage range of Platte River at Louisville, Nebraska (USGS 06805500), during three survey periods, 2011.

[Data are approved values retrieved from the U.S. Geological Survey National Water Information System on February 13, 2012.]

\begin{tabular}{|c|c|c|c|c|c|}
\hline \multirow{2}{*}{$\begin{array}{l}\text { Survey period } \\
\text { and date }\end{array}$} & \multicolumn{4}{|c|}{ River discharge, in cubic feet per second } & \multirow{2}{*}{$\begin{array}{c}\text { Stage range } \\
\text { (feet) }\end{array}$} \\
\hline & Maximum & Minimum & Average & Range & \\
\hline \multicolumn{6}{|c|}{ Spring survey period } \\
\hline 04/06/2011 & 12,900 & 9,810 & 11,400 & 3,090 & 0.45 \\
\hline 04/07/2011 & 13,600 & 9,930 & 11,700 & 3,670 & 0.53 \\
\hline $04 / 08 / 2011$ & 13,500 & 9,810 & 11,400 & 3,690 & 0.54 \\
\hline $04 / 12 / 2011$ & 12,300 & 8,940 & 10,500 & 3,360 & 0.41 \\
\hline Average & 13,075 & 9,623 & 11,250 & 3,453 & 0.48 \\
\hline \multicolumn{6}{|c|}{ Summer survey period } \\
\hline 07/26/2011 & 13,100 & 8,120 & 10,500 & 4,980 & 0.76 \\
\hline $07 / 27 / 2011$ & 12,300 & 8,410 & 10,200 & 3,890 & 0.6 \\
\hline 07/28/2011 & 13,200 & 8,700 & 11,300 & 4,500 & 0.68 \\
\hline 07/29/2011 & 14,200 & 9,870 & 12,000 & 4,330 & 0.62 \\
\hline 08/02/2011 & 12,100 & 7,560 & 9,930 & 4,540 & 0.72 \\
\hline Average & 12,980 & 8,532 & 10,786 & 4,448 & 0.68 \\
\hline \multicolumn{6}{|c|}{ Fall survey period } \\
\hline $10 / 31 / 2011$ & 9,740 & 6,650 & 8,190 & 3,090 & 0.54 \\
\hline $11 / 01 / 2011$ & 9,550 & 7,070 & 8,270 & 2,480 & 0.43 \\
\hline $11 / 03 / 2011$ & 10,600 & 7,180 & 8,960 & 3,420 & 0.57 \\
\hline $11 / 04 / 2011$ & 10,100 & 7,340 & 8,710 & 2,760 & 0.47 \\
\hline Average & 9,998 & 7,060 & 8,533 & 2,938 & 0.50 \\
\hline
\end{tabular}


sandbar areas between survey periods (summer-spring, fallsummer, and fall-spring). Changes were quantified using basic summary statistics of differences in sandbar areas between survey seasons by sandbar type. Because there was no practical way to normalize sandbar area to an index discharge, and because characteristics of the entire population of sandbars were recorded, no inferential statistical analyses of differences in means or variances of emergent sandbar area were performed when comparing sandbar types or seasons.

\section{Sandbar Height}

The height of sandbars is a direct measure of the potential (probability) for inundation of a sandbar by a discharge having a particular stage, and is, therefore, one metric for the relative quality of tern and plover nesting habitat because it is directly related to the potential for inundation (causing nest failure) in any given year (Parham, 2007; Brown and Jorgensen, 2008; Lott and Willey, 2012). Sandbars in the study segment generally had an easily identifiable, tabular high surface (hereinafter, the "high platform"; fig. 3), which gently sloped downstream. In some cases, the high platform had low-relief undulations, or the sandbar was dissected into series of individual tabular areas separated by shallow, cross-bar eroded threads. Undulations and mud drapes were particularly noticeable during the spring survey, and these were assumed to be the result of backwater flooding caused by ice jams. For example, the peak stage recorded in 2011 at the Louisville gage was recorded on February 17, and was related to backwater flooding from ice, as opposed to the annual instantaneous maximum discharge, which occurred on May 27, 2011 (U.S. Geological Survey, 2012). During the subsequent summer and fall surveys, the high platforms of sandbars were less undulating, and had less mud, indicating they had been reworked (or resurfaced) either by wind or water.

\section{Field Data Collection}

Sandbar height was surveyed for all sandbars with a fieldestimated size of more than 2 acres. Measurements of sandbar height were focused on characterizing the field-perceived high platform (fig. $3 A$ ) because it could be compared to the stage of the formative flow and was the part of the sandbar that was assumed to be the most-probable and highest-quality nesting habitat for terns and plovers. In some cases, one or two extensive flat surfaces were inset and lower relative to the highest surface, but the height of these lower surfaces was not surveyed (figs. $3 A$ and $B$ ). Sandbar height was surveyed using a rotating laser level mounted on a tripod and a laser detection receiver mounted on a graduated stadia rod. The rotating laser level had a radial range of $750 \mathrm{ft}$ and a nominal accuracy of about $\pm 0.0033 \mathrm{ft}$ per $100 \mathrm{ft}$ along the radius. In most cases, sandbar height was surveyed by taking a series of 5-9 point measurements on the high platform (figs. $3 A-C$ ); however, in rare cases fewer or more points were taken. To negate bias in each height measurement caused by the slope of the sandbar surface, measurements of sandbar height were referenced to adjacent point measurements of the water surface. In rare cases, water-surface height was linearly interpolated upstream or downstream to a point adjacent to a sandbar height measurement where no water-surface height had been surveyed. The location of point measurements of sandbar height and water-surface height was recorded using either a WAASenabled recreational GPS unit, or logged into a handheld DGPS receiver similar to that used for sandbar area. The exact collection time of all point measurements of water-surface height was either recorded in a field notebook, or logged directly into the GPS unit.

Spacing of point measurements of sandbar height was determined in three different ways, depending on the shape of the sandbar. For sandbars that were prismatic in shape, point samples of sandbar heights were collected using a quasi-grid approach that weighted the number of point measurements to larger (wider) parts of the sandbar (more points were taken in wider areas than in narrower areas) (fig. $3 A$ ). For sandbars that had a simplistic streamwise elongated shape and a singular, unbroken high platform, a rectangular grid system was used to locate point samples of sandbar height along equally spaced transects (fig. $3 B$ ). The rectangular grid was established by: (1) using a laser rangefinder to estimate the streamwise center of the high platform; (2) setting the rotating laser level at the estimated streamwise center of the high platform; and (3) surveying equally spaced point measurements of height along transects aligned perpendicular to the high banks of the channel, and equally spaced at the approximate 25th, 50th, and 75 th percentiles of the length of the high platform. For sandbars that had a dissected topography, or those that were split by a series of shallow channels, point measurements of sandbar heights were taken on all individual bar units that had a maximum height approximately equivalent to the high platform of the core bar, and the number of point measurements were weighted approximately proportional to the field-estimated relative size of each bar's high platform area (fig. $3 C$ ). Sandbars that were nearby, but separated from the core channel by a deep, non-wadeable, channel thread, were considered independent bar units.

The natural high banks of the river also were measured relative to the water surface to provide an additional reference datum where possible. The term "natural high banks" is used to refer to banks of the river that are not constructed or otherwise perceptibly directly altered by humans, and that have a mature riparian forest community, typically indicated by nearly vertical banks without bank protection and the presence of riparian trees of large diameter. Measurements of the heights of the natural high banks only occurred during the spring and summer survey periods. The locations of sampling areas for the heights of the high banks were dictated mainly by availability because much of the study segment has bank protection; however, nearness to a surveyed sandbar also was a consideration. Heights of high banks were measured by placing a graduated stadia rod at water's edge near the bank, and holding the stadia rod plumb while a second operator used 
a hand level to align the brink of the top of the bank with the scale on the rod. The height of the bank, the location of the measurement, and the exact time of the measurement were recorded. Because of the undulating and diffuse (grassy, illdefined brink) nature of the bank tops, three height measurements, spaced about 50-150 ft apart, were taken and averaged for every bank sampling area.

\section{Data Analysis}

Because all sandbar heights were paired with an adjacent measurement of water-surface height, and the water-surface height in the LPR has a diel fluctuation, adjustments to each measured water-surface height were necessary to standardize sandbar heights to a common datum. Height standardization was done using simplifying assumptions of the hydrology and hydraulics of the study segment, and a spatial-temporal interpolation technique. First, it was assumed that stage changes at two streamflow-gaging stations, the Ashland and Louisville gages, were broadly representative of the magnitudes of stage changes throughout the study segment, and that stage changes throughout the study segment could be reasonably characterized using the rating tables from these gages. Second, it was assumed that the instantaneous stage at a location in the river away from a streamflow-gaging station could be represented by an interpolated stage if the streamwise distance and the travel time of water between the streamflow-gaging station and survey point were known. The first assumption is recognized to be a potential oversimplification of the system; however, such an assumption is necessary in the absence of many additional streamflow-gaging stations throughout the study area. Furthermore, the study area has less variation in channel width than segments upstream (Elliott and others, 2009), and, therefore, likely has less overall streamwise variation in stagedischarge relations.

Each surveyed water-surface height was indexed to two primary reference heights: (1) the stage of the water-surface at 4,000 $\mathrm{ft}^{3} / \mathrm{s}$ (Ziewitz and others, 1992) at the nearest gaging station, and (2) the height of the nearest bank-height measurement of the high banks of the river. To index individual water-surface heights, which were taken over variable times of the day and at various locations throughout the river, each measurement was first referenced to an interpolated stage at the nearest streamflow-gaging station using the following equations:

$$
T_{X}=\frac{X_{G}-X_{i}}{\bar{V}}
$$

where

$$
\begin{array}{cc}
T_{X} & \begin{array}{c}
\text { is the time offset between location } X \text { and } \\
\text { the nearest streamflow-gaging station, in } \\
\text { hours; }
\end{array} \\
X_{G} & \begin{array}{c}
\text { is the streamwise location of the nearest } \\
\text { streamflow-gaging station, in miles; }
\end{array} \\
X_{i} & \begin{array}{c}
\text { is the streamwise location of water-surface } \\
\text { height point measurement } i, \text { in miles; and }
\end{array}
\end{array}
$$

$\bar{V} \quad$ is the average velocity of a parcel of water between the streamflow-gaging station and the water-surface height point measurement, in miles per hour.

The interpolated stage at location $X$ for measurement $i$ was obtained from the instantaneous (15-minute intervals) stage record of the stream gage at $X_{G}$ :

$$
S_{X_{i}}=S\left(t_{i}-T_{X}\right)
$$

where

$$
\begin{gathered}
S_{X_{i}} \quad \begin{array}{c}
\text { is the interpolated stage from the nearest } \\
\text { gaging station of the individual water- } \\
\text { surface height measurement } i \text {, in feet; }
\end{array} \\
t_{i} \quad \begin{array}{c}
\text { is the time of the individual water-surface } \\
\text { height measurement } i \text {, in feet; }
\end{array} \\
T_{X} \quad \text { is as before. }
\end{gathered}
$$

Once the interpolated stage was calculated, the height of individual sandbar measurements relative to the interpolated stage of the river at $4,000 \mathrm{ft}^{3} / \mathrm{s}$ was calculated as:

$$
Z_{4 k_{j}}=Z_{X_{j_{i}}}-\left[S_{X_{i}}-S_{4 k}\right]
$$

where

$$
\begin{aligned}
& Z_{4 k_{j}} \quad \text { is the height of an individual point } \\
& \text { measurement of sandbar height } j \text { above the } \\
& \text { interpolated local stage of } 4,000 \mathrm{ft}^{3} / \mathrm{s} \text {, in } \\
& \text { feet; } \\
& Z_{X_{j_{i}}} \quad \text { is the height of an individual point } \\
& \text { measurement } j \text { on the sandbar high } \\
& \text { platform adjacent to water surface height } \\
& \text { measurement } i \text {, in feet; } \\
& S_{X_{i}} \quad \text { is as before; } \\
& S_{4 k} \quad \text { is the stage of } 4,000 \mathrm{ft}^{3} / \mathrm{s} \text { from the rating table } \\
& \text { of the streamflow-gaging station at } X_{G} \text {, in } \\
& \text { units of length. }
\end{aligned}
$$

The streamwise distances between the streamflow-gaging stations and each water-surface height point measurement were determined using a linear referencing tool in the GIS. The average velocity of a water parcel between the watersurface height measurement point and the nearest streamflowgaging station was determined using a stage-correlation technique. The stage-correlation technique progressively lagged the 15-minute stage record of an upstream gaging station, in 15-minute time steps (fig. $4 A$ ), and calculated the Pearson's correlation coefficient between the lagged record and the downstream stage record at each time step. The average water-travel time was assumed to be the time offset for which the two records reached maximum correlation (fig. 4B). Other studies have used this type of correlation analysis method to estimate bedform migration velocities (Dinehart, 2002; Holmes, 2010), and this method inspired the technique used in this study.

Stage correlation entailed using a 72-hour window of instantaneous (15-minute) stage records, centered on the survey day of interest, and included additional, stage-only gaging 
stations. To increase the spatial resolution of the records for the diel wave in river stage, and, therefore, to allow spatial differences in average travel time to be assessed, two additional stage-only gaging stations were installed for this study: one at South Bend, Nebraska (USGS station 06805020, hereinafter referred to as "the South Bend gage"), and one at La Platte, Nebraska (USGS station 06805570, hereinafter referred to as "the La Platte gage") (fig. 1). Travel time was estimated between each gaging-station pair for each day on which a sandbar survey occurred to account for day-to-day variations in travel time owing to weather and minor discharge changes (appendix 1, tables 1-1 through 1-3). In some cases, a full 72-hour stage record was not available for all streamgages because gaging-station equipment malfunctioned. In such cases, a shorter time period centered on a day other than the survey date was used to make the correlations. The height of the high banks relative to the $4,000 \mathrm{ft}^{3} / \mathrm{s}$ reference stage was calculated using the same techniques as described in equations 1-3 for indexing measurements of sandbar height.

Assessment of changes in sandbar height between seasons and changes in the longitudinal pattern of sandbar heights only focused on those sandbars that were larger than 2 acres because few measurements of height were made on sandbars smaller than 2 acres. Four types of statistical summaries were assessed. First, cumulative frequency distributions of measured sandbar heights were constructed for each survey period, and simple comparisons of these curves and summary statistics were made. This simple assessment was considered rigorous because measurements were made on the high platform of the entire population of emergent sandbars larger than 2 acres. Second, scatter plots of measurements of sandbar heights by longitudinal location were constructed, and locally weighted least-squares regression (LOESS) lines were fit to the data using a span of 0.4 (fraction of sample size), and a linear, symmetric fit (Helsel and Hirsch, 2002). The LOESS lines were used to visually evaluate patterns in the alongstream distribution of sandbar heights, and to compare any noted patterns with coincident along-stream patterns in channel sinuosity (Elliott and others, 2009), channel width (Elliott, 2011), and height of the high banks (this study). Third, the frequency distributions of median and maximum measured values of sandbar height were compared among survey periods and sandbar types. These particular summary statistics were selected because quality-control data (described in the "Quality Control" section of this report) indicated that median and maximum values provided the strongest evidence of overlap with tern nesting heights. Finally, the two-tailed Wilcoxon signed-rank test (Helsel and Hirsch, 2002) was used to test
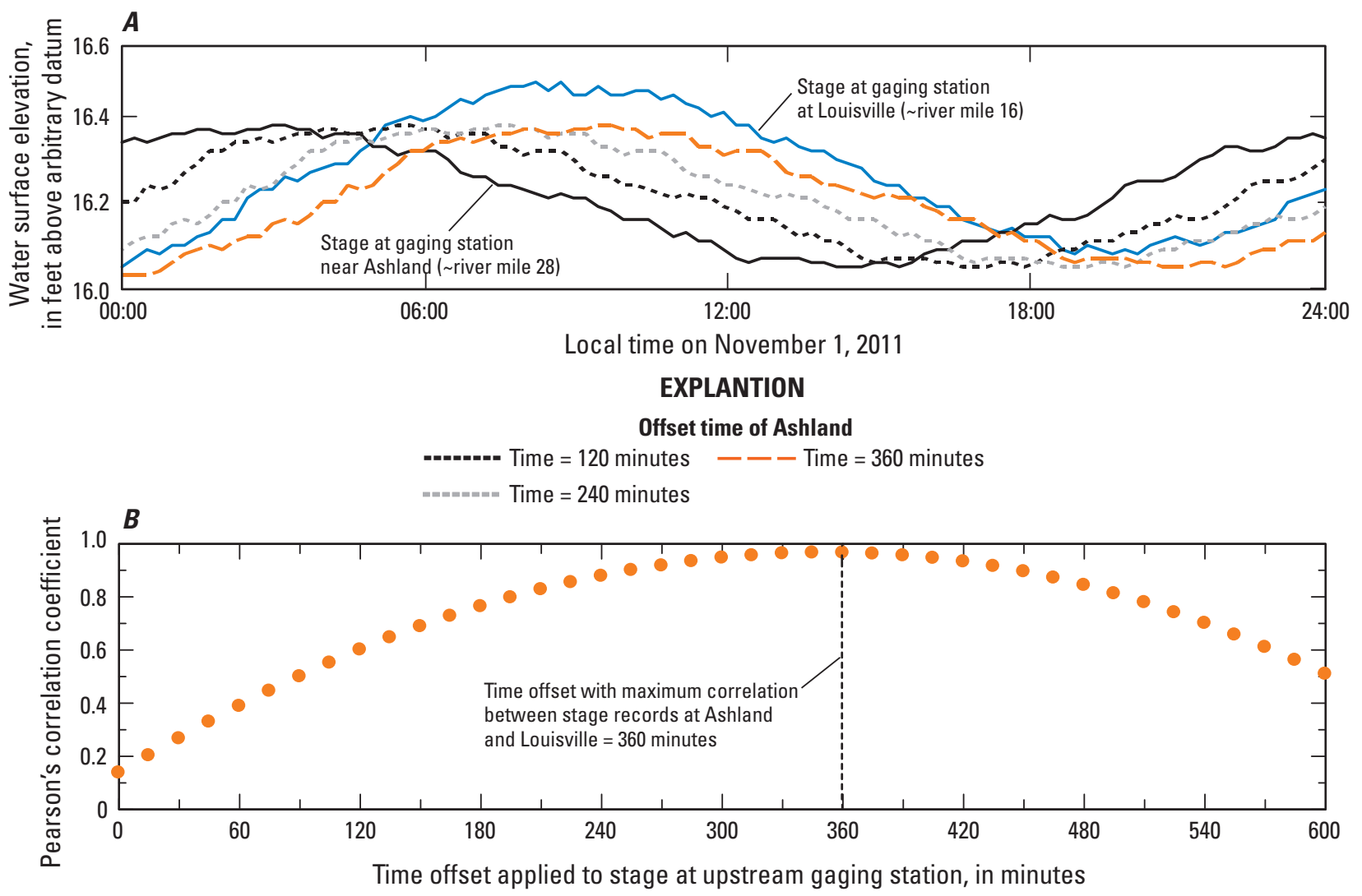

Figure 4. Example of stage-correlation method used to estimate travel time of water between gaging stations by $(A)$ comparison of stage hydrographs with various offset hydrographs; and $(B)$ results from correlation analyses comparing downstream hydrograph with various offset hydrographs of upstream stage hydrograph. 
for significant differences of sandbar height between survey periods among sandbar pairs. A non-parametric test was used because the data indicated the potential for non-normality in the sandbar height dataset for the summer survey.

\section{Sandbar Location}

Data describing the location and spatial distribution of sandbars, and particularly the spatial distribution of sandbar area, are important for understanding if sandbars are uniformly or randomly distributed along the river, or if certain locations in a river tend to be more conducive to deposition and formation of emergent sandbars of high quality as nesting habitat. Such information could be used in a variety of ways. For example, an understanding of flow conditions in areas where high-quality emergent sandbars tend to form, persist, or both may be critical to develop simulation models for predicting the expected availability and quality of habitat on the basis of flow conditions. Additionally, such information is valuable for planning sustainable habitat creation or restoration projects if it enhances the likelihood of sandbar persistence, and, thus, the cost-effectiveness of constructed habitats.

\section{Field Data Collection}

The location of each sandbar was approximated in one of two ways, depending on the size of the sandbar. For sandbars of less than 2 acres, the bar centroid was estimated by recording a GPS location of the boat and an offset distance and azimuth (uncorrected for declination) to the approximate center of the sandbar, which were estimated using a laser rangefinder with an internal digital compass. The GPS points then were manually post-processed in a GIS, using the offset distance and azimuth (uncorrected for declination) to create point features at the estimated center of each sandbar smaller than 2 acres.

For sandbars larger than 2 acres, the centroid of each was calculated from the GIS polygon representation of the surveyed perimeter of the dry crest, and that centroid was used as the sandbar's location. The centroid of the largest sandbar was used as the location for complexes of multiple sandbars. The point location of each sandbar was referenced linearly in the GIS to river distance upstream from the Missouri River-Platte River confluence along the channel centerline of the Platte River (Elliott and others, 2009).

\section{Data Analysis}

Sandbar locations and spatial distributions were assessed in two primary ways. First, the sandbar area was summed by river-mile increments for each survey period, and expressed as a percentage of the total emergent sandbar area for the same period, to assess the streamwise distribution of emergent sandbar area by river mile. Expressing area as a percentage of period total reduces the influence of between-period differences in streamflow discharge on the interpretation of spatial distributions of sandbar area. Second, shifts in sandbar location between survey periods were assessed using repeated survey results for individual sandbars (data pairs for presumed same sandbar). Data pairs for location assessments were the same as those identified for the paired-test statistical comparison of sandbar height (described in the "Sandbar Height: Data Analysis" section of this report). Shifts in sandbar location within a data pair were characterized as the difference in the streamwise location of the sandbar areal centroids for springsummer, summer-fall, and spring-fall collocated sandbar pairs. Summary statistics for shift in location (including mean, median, interquartile range, and range) were used to quantify the magnitude and direction (upstream or downstream) of shifts.

\section{Quality Control}

Two primary procedures were implemented as checks on the quality of field measurements of sandbar geometry. First, surveys of sandbar area and height were replicated at 10 percent or more of sandbars larger than 2 acres. Second, a quality-control survey was used to compare sandbar area and height results measured using the rapid-assessment approach with those from a more detailed survey measured with a laser total-station system. Additional quality-control procedures were used to approximate the uncertainty of estimations of sandbar height associated with errors in estimation of water travel time and to validate predictions of sandbar inundation. These additional procedures are described in appendixes 1 and 2 , respectively.

\section{Replicate Surveys of Sandbar Geometry}

Surveys of sandbar geometry were replicated for at least 10 percent of all sandbars surveyed during each survey period. Under ideal conditions, a sandbar was randomly selected for survey replication as one of the first seven sandbars surveyed on each day of each survey period, and the set of replicates would cover the range of sizes in the population of sandbars being surveyed. However, when the sandbar chosen at random either was (1) too similar in size to a sandbar from the previous survey day, or (2) was too large for survey replication while maintaining overall efficiency, a different sandbar was chosen for survey replication. In a couple of cases, replicates of sandbar area were surveyed simply because time allowed for the technician to make an additional pass around the sandbar before height measurements were concluded. No replicate surveys were performed on sandbars with resident tern or plover colonies to minimize disturbance to those species.

Replicate surveys of sandbar geometry were performed differently and served two different purposes, depending on the geometric component being measured. Replicate surveys of sandbar area were performed by walking the same route 
around the sandbar twice with the handheld DGPS unit held in the same position. Replicate surveys of sandbar height were performed by moving the rotating laser level upstream or downstream an arbitrary distance of 10-50 ft, re-approximating a second survey grid with the laser rangefinder, and performing a second survey, with all point measurements thus offset from the first. The distance the rotating laser level was moved was more for sandbars with large high platforms and less for those with smaller high platforms. Replicate surveys of sandbar area allowed approximations of uncertainty in the measured sandbar area caused by positional variations in the DGPS-surveyed points resulting from any or a combination of three sources: (1) small-magnitude deviations in technician's route reflecting recognizability of the dry crest's edge,

(2) variations in the way the technician held the GPS unit (possible effects on multi-path signal reception), or (3) variations in precision caused by differences in GPS satellite coverage between the individual replicate surveys. Replicate surveys of sandbar height provided estimations of uncertainty in the measured height of a sandbar caused by differences in human perception of the high platform extent and shape, as evidenced by differences in the placement of the rotating laser level and the layout of the survey grid, and ultimately resulted in different locations of spot measurements of height. Because the same operator always collected both replicates of either sandbar height or sandbar area at a specific sandbar, the resulting data do not allow an estimate of uncertainty attributed to observer bias.

\section{Data Analysis}

Two primary methods were used to characterize uncertainty of replicated sandbar-geometry measurements: (1) summary statistics, including confidence intervals on the mean difference between data pairs, and (2) two-tailed Wilcoxon signed-rank tests of data pairs. For sandbar area, data pairs were the paired original and replicate survey result. For sandbar height, spot measurements of height from original and replicate surveys were paired based on rank, as opposed to position in the survey grid, because differences in sandbar height ultimately were evaluated for ranked data values (median and maximum), and these values are not associated with location within the survey grid. Summary statistics and confidence intervals were computed for differences between ranked data pairs, and statistical tests of difference were performed to evaluate differences in median and maximum sampled data. A non-parametric statistical test was used because at least some of the datasets potentially appeared to be non-normally distributed, and replicate sample sizes were too small to confidently determine the normality of distributions.

\section{Detailed Surveys of Sandbar Topography}

Although replicate surveys of sandbar areas and geometries addressed the variability of measurements associated with surveying using the same method, replicate surveys could not address three other areas of concern: (1) the accuracy of the absolute magnitude of areas being measured with the handheld DGPS units, (2) confidence in the field technician's ability to perceive the highest part of the sandbar topography, and (3) the representativeness of rapid-assessment bar height measurements relative to the height of tern and plover nesting locations on the same bar. To address these concerns, a quality-control survey of sandbar topography was conducted during a 2-day period, independent of the three primary survey periods, and outside the tern and plover nesting season.

On the first day, the rapid-assessment method was used to survey the height and area of four bars ranging in size from 3.40 to 29.2 acres. Flagging was used to mark the locations of point measurements of sandbar height taken with the rotating laser level so they could be precisely relocated. Two of the four sandbars had confirmed nesting of interior least terns during summer 2011 (Joel Jorgensen, Nebraska Game and Parks Commission, written commun., 2011).

On the second day, the topography of the same four sandbars was surveyed using a total station. The total station was placed near the center of the sandbar to minimize the greatest measurement distance. The manufacturer's specifications for the total station indicated a horizontal and vertical accuracy of about $\pm 0.01 \mathrm{ft}$ per $1,000 \mathrm{ft}$ of distance when using a reflector prism (Sokkia Company, 2004). Sandbar topography on each sandbar was surveyed along 10 transects spaced evenly across the longitudinal length of each sandbar (fig. 5). The edges of the dry crest were encoded along each transect data series. Point spacing of topographic measurements along each transect generally was determined by equal increments; however, different technicians used slightly different spacing when walking, and additional points were surveyed to capture major topographic slope breaks. Point measurements of sandbar topography also were surveyed at the flagged locations where height measurements were taken with the rapidassessment method, as well as on the sandbar surface next to nest scratches and bowls on the two sandbars where previously used nests were present. In some cases, tern or plover scrapes had eggshell remnants, and, in other cases, no eggshell remnants were present. Scrapes were assumed to have been either used for nesting or initially excavated as potential nesting locations by terns or plovers. In either case, the authors assumed that the scrapes were roughly representative of the heights used by terns and plovers for nesting in 2011.

\section{Data Analysis}

To address the accuracy of sandbar area measurements made using the rapid-assessment method, the areas of polygons made from the DGPS survey were compared with those made using the total-station survey data. Polygons of the sandbar area were generated from the topographic data surveyed with the total station by connecting the dry-crest edge points of each transect along the outside of the sandbar. Although this type of polygon is crude compared to the detailed outline of the dry crest taken using the DGPS survey, the transect density 
was sufficient to encompass the general outline of the sandbar and to identify any large-magnitude differences between the DGPS and total-station surveys.

A cumulative frequency distribution of topography was generated from the topographic points surveyed with the total station to address the ability of the technician to identify the high platform of a bar and to provide some characterization of how well measurements of height using the rapid-assessment method captured the highest topography of the sandbar. Several steps were taken to remove bias in the topographic distribution associated with the downstream slope of the sandbar. First, the height of each water-surface point was corrected for water-stage fluctuations using a linear time-based interpolation and the net change in stage recorded over the time of the total-station survey (observed on a temporary staff plate). Second, survey points of the water surface from the total station were located along a straight line drawn through the center of the sandbar using an addressing tool in a GIS. Next, an ordinary least-squares regression line (Helsel and Hirsch, 2002) was fit to the stage-indexed heights of surveyed water-surface points along the length of the sandbar. Finally, the slope of the ordinary least-squares regression line was

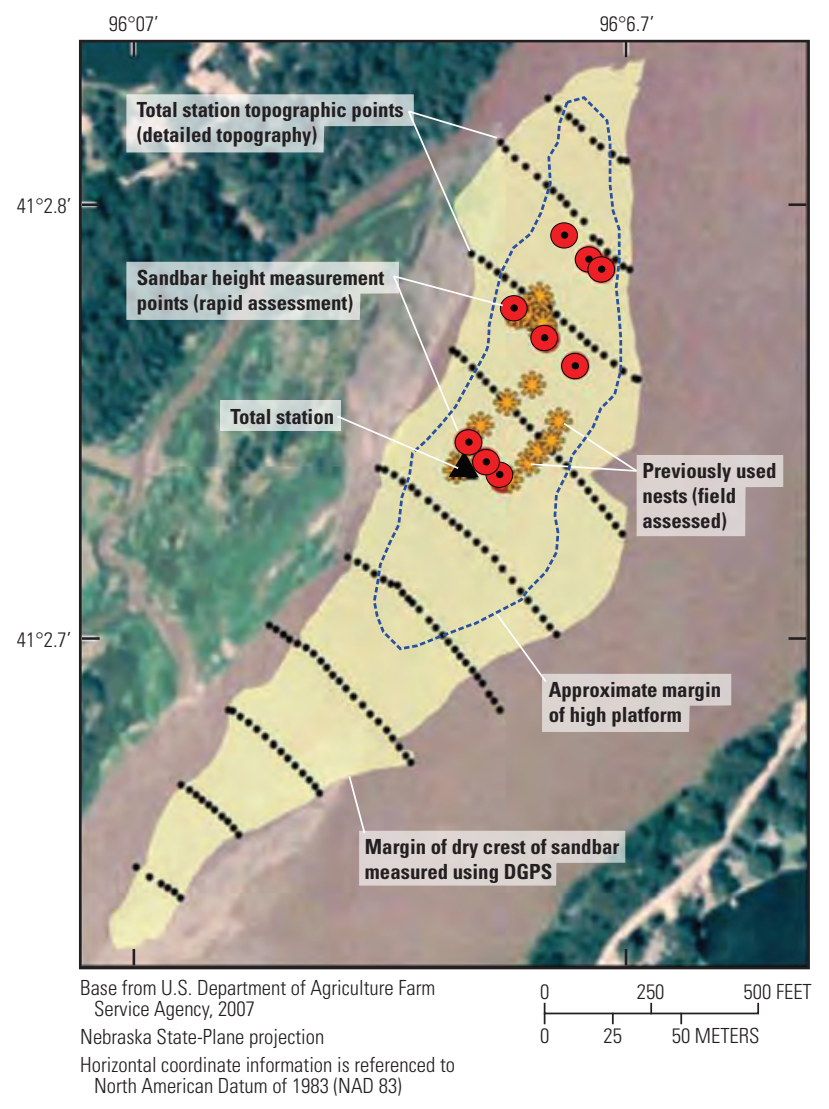

Figure 5. Examples of point-and-transect spacing of detailed topographic measurements collected with a total-station system, summer 2011; locations of previously used tern nests interpreted by field technicians; and locations of spot heights measured using the rapid-assessment survey method, lower Platte River, Nebraska, 2011. used to normalize the topographic points from the total-station survey to an interpolated flat-water surface. The cumulative topographic distribution did not include the points collected to measure water-surface height. The nest heights and highplatform heights surveyed using the rapid-assessment methods were then compared to the percentiles of sandbar height from the cumulative topographic distribution of the sandbar.

\section{Emergent Sandbar Dynamics in the Lower Platte River}

Along the 22-mi study segment, the variation from reach to reach in percentage of total emergent sandbar area and range of sandbar heights generally was consistent between survey periods (seasons). The highest part of many sandbars formed by the peak discharge in 2010 remained emergent above the stage of the peak discharges of 2011, but these subsequent flows caused a net lowering of sandbars overall. Analysis of quality-control data indicated that the rapidassessment method developed for this study was sufficiently sensitive to document the changes in sandbar height and area measured between seasons.

\section{Seasonal Differences in Number and Areas of Emergent Sandbars}

Average streamflows at the Louisville gage during the spring, summer, and fall survey periods were 11,250, 10,786, and $8,533 \mathrm{ft}^{3} / \mathrm{s}$, respectively - a discharge differential of as much as 30 percent, and an average stage range of about $0.43 \mathrm{ft}$ at the Louisville gage (based on rating number 14, M.J. Andersen, U.S. Geological Survey, written commun., 2011). Nevertheless, the diel fluctuation in river discharge because of hydrocycling within each survey period resulted in overlap in the daily ranges of discharges between periods (table 1). Stage ranges were as much as $0.76 \mathrm{ft}$ during a single day, indicating that the measurements of sandbar area across survey periods had enough overlap to be comparable, but likely had some relative bias, particularly for comparisons with the fall survey period when discharges in the LPR were much lower than during the two previous survey periods.

The area of 68 sandbars, with a total estimated emergent area of 360 acres, was measured or estimated during the spring survey period (table 2). Eighty-five percent of the total estimated emergent sandbar area during the spring survey period was contained in the 25 sandbars surveyed with the DGPS method, of which only one was smaller than 2 acres. Measured emergent sandbar areas ranged from about 1.90 to 39.9 acres, with a median sandbar area of about 10.5 acres. Mid-channel sandbars were the most abundant of the three measured sandbar classes, and ranged in emergent area from 1.90 to 22.5 acres (fig. 6). There were few island-attached sandbars during the spring survey, but these sandbars were generally 


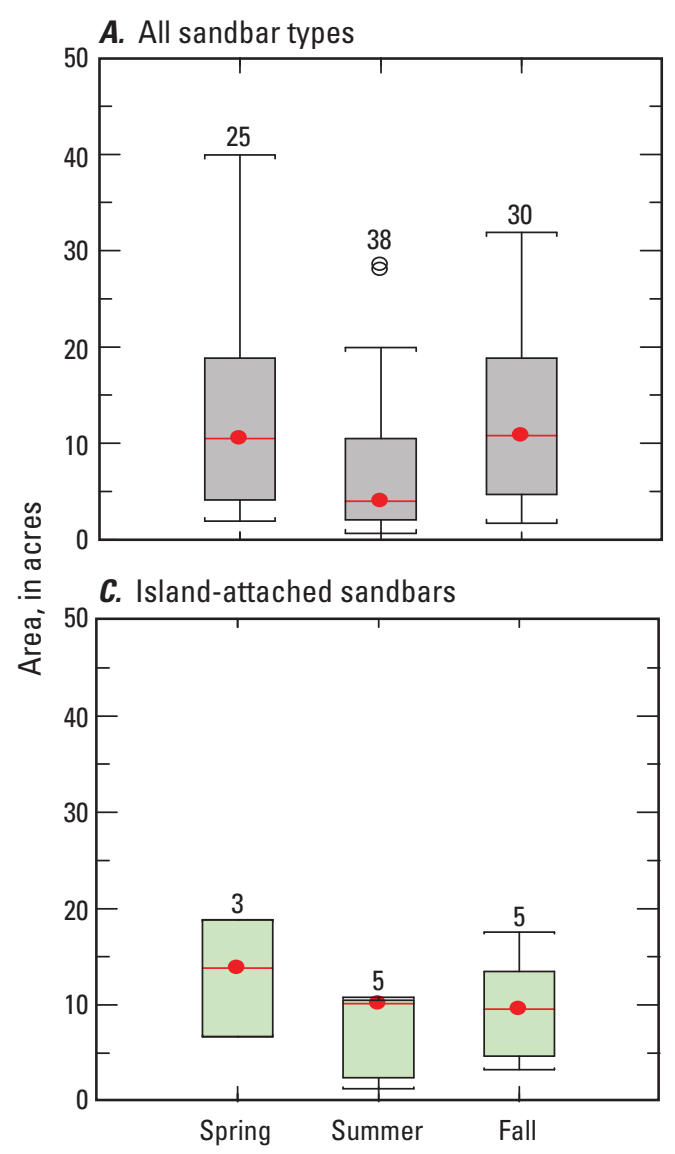

B. Mid-channel sandbars

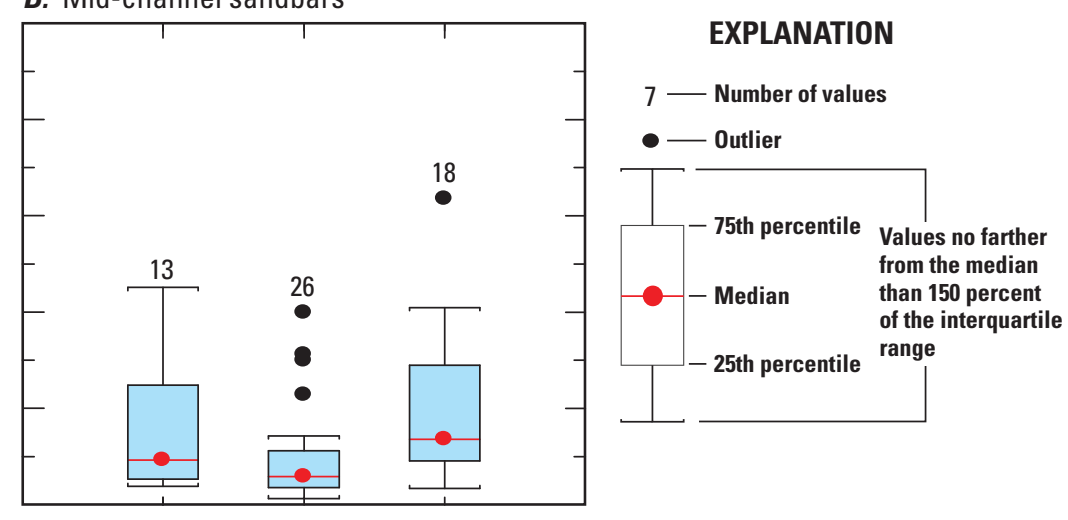

D. Bank-attached sandbars

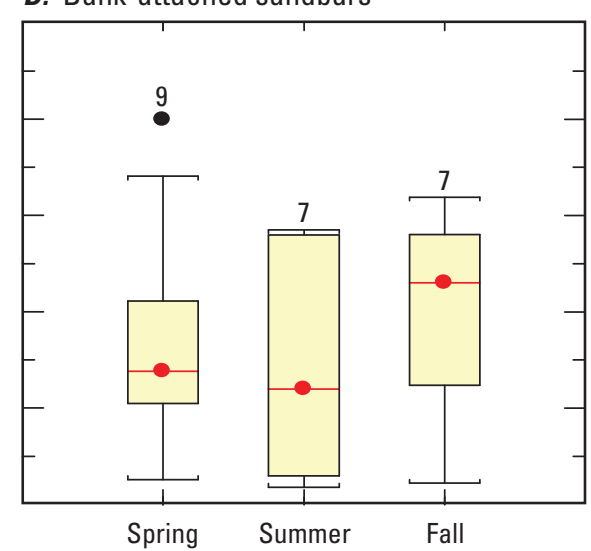

Figure 6. Frequency distribution of emergent sandbar area by survey period and sandbar type, lower Platte River study segment, Nebraska, 2011: $(A)$ all bar types, $(B)$ mid-channel sandbars, $(C)$ island-attached sandbars, and $(D)$ bank-attached sandbars. Data shown are for sandbars measured using differential-grade global-positioning system, and are generally restricted to sandbars larger than 2 acres.

large, ranging in emergent area from about 6.70 to 18.9 acres. Bank-attached sandbars contributed about half of the total measured emergent sandbar area during the spring survey period (table 2), with a median area of 13.8 acres, the largest of the three sandbar classes (fig. 6).

A total of 105 sandbars, with a total estimated emergent area of 315 acres, were surveyed or estimated during the summer survey period (table 2). Thirty-eight of these sandbars were measured using DGPS, of which 9 were smaller than 2 acres. Measured sandbars contributed about 84 percent of the total emergent sandbar area (table 2), and sandbars larger than 2 acres contributed about 80 percent of the total. A decrease in total emergent sandbar area apparently had occurred since the spring survey despite slightly lower daily streamflows relative to the spring survey period (table 1). The decrease in sandbar area primarily was the result of a decrease in the total area of bank-attached sandbars (table 2). Despite a decrease in median and maximum individual area, midchannel sandbars increased in total number as well as in total emergent area (table 2), indicating that the intervening high flows not only dissected larger mid-channel bars into smaller bars, but also created a number of new emergent mid-channel sandbars.

Seventy-three sandbars, with a total estimated emergent area of 402 acres, were measured during the fall survey period. The increase in sandbar area occurred despite a net decrease in total number of emergent sandbars and was a consequence of the lower average daily flows during the fall survey period relative to the summer and spring survey periods (table 1). More than 90 percent of the total estimated emergent sandbar area was contained in the 30 sandbars measured using DGPS, 29 of which were larger than 2 acres. Much of the increase in emergent area occurred by an increase in the area of midchannel sandbars larger than 2 acres, despite a net decrease in the total number of these types of bars, indicating that a substantial area of shallow-water habitats had surrounded the larger mid-channel sandbars, and this area emerged because of lower flows.

Intersection of sandbar polygons from each survey season resulted in 17 collocated sandbars common to the spring and 
Table 2. Number and total measured and estimated areas of emergent sandbars in the study segment of the lower Platte River, Nebraska, by bar type and survey period, 2011.

[Measured sandbar areas, Emergent sandbar areas measured using differential-grade global-positioning system (DGPS) by walking perimeter of dry crest; generally only includes sandbars larger than 2 acres; Estimated sandbar areas, Emergent sandbar areas estimated using laser rangefinder; generally only includes sandbars less than 2 acres. With few exceptions, these were low, mid-channel bars; $\mathrm{n}$ with area, $<2.0$ acres, number of sandbars measured using DGPS method that were eventually calculated to be less than 2 acres; Total estimated emergent sandbar area, total may differ from sum of subtotals because of rounding; n, sample size; $<$, less than]

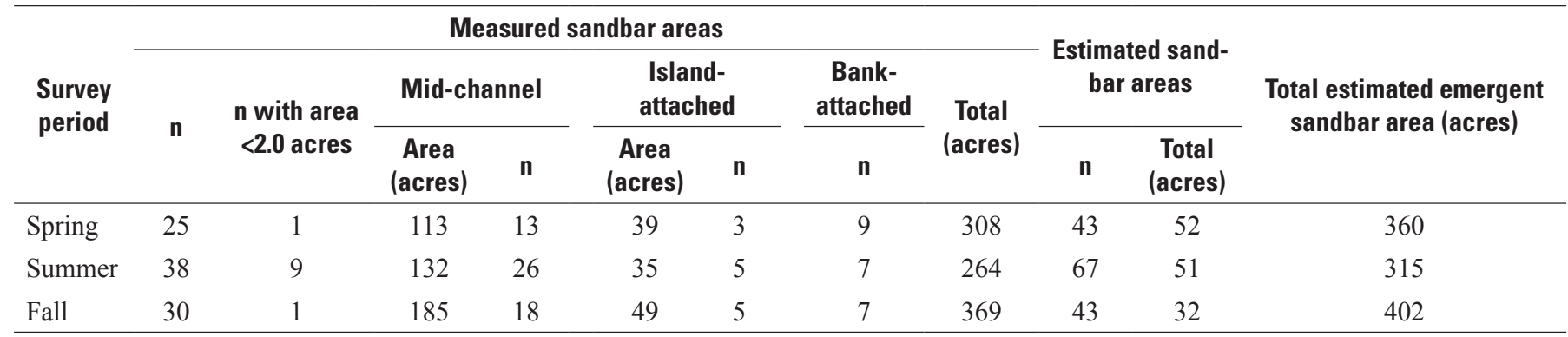

summer survey periods, 27 collocated sandbars common to the summer and fall survey periods, and 21 collocated sandbars common to the spring and fall survey periods (fig. 7).

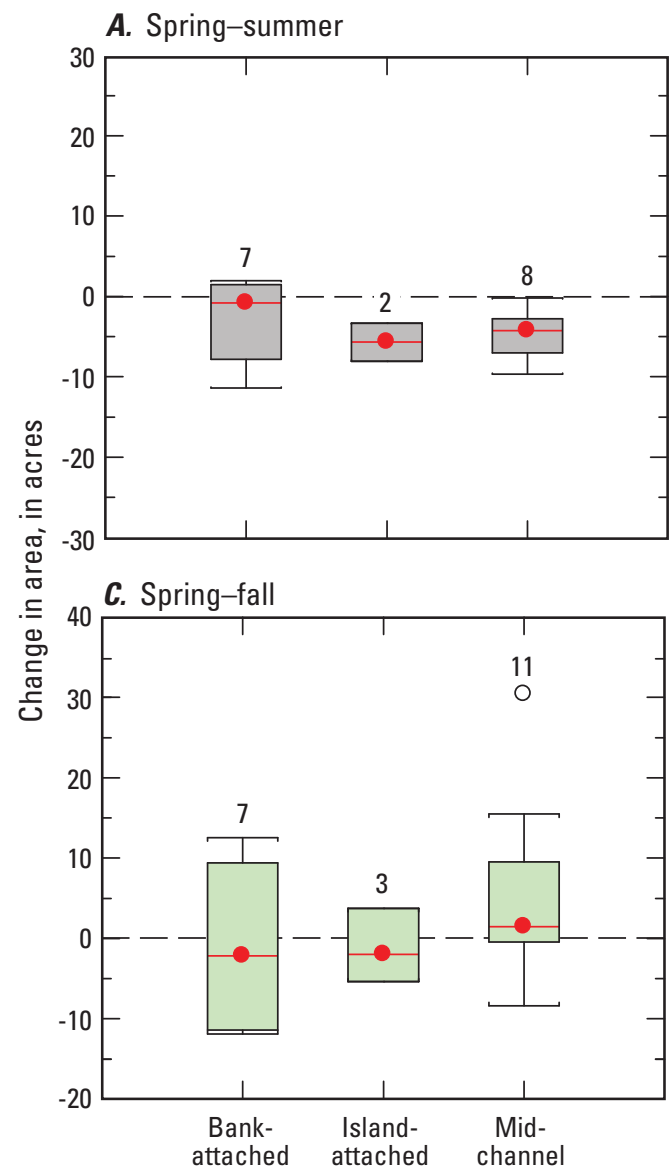

B. Summer-fall

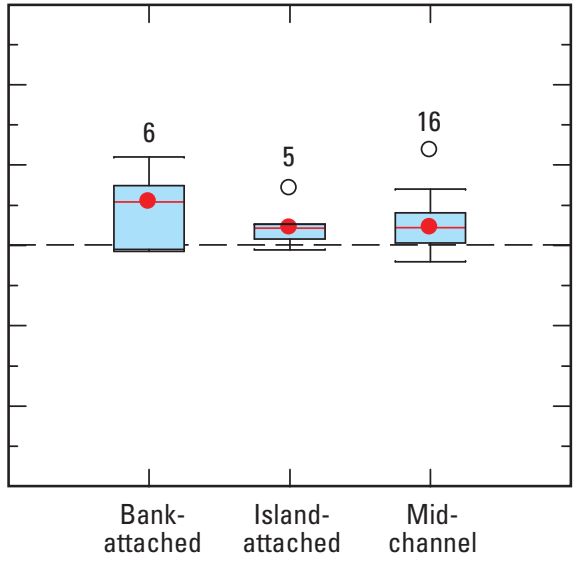

EXPLANATION

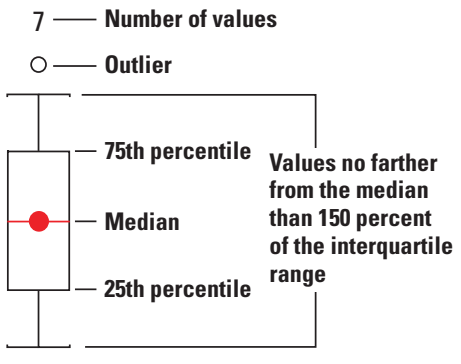

Figure 7. Frequency distributions of differences in emergent sandbar area among collocated pairs of sandbars between survey seasons by sandbar type, lower Platte River, Nebraska, 2011: $(A)$ spring-summer difference, $(B)$ summer-fall difference, and $(C)$ spring-fall difference. Data shown are for sandbars measured using handheld differential-grade global-positioning system, and are generally restricted to sandbars larger than 2 acres.
The larger number of collocated sandbars common to the spring and fall survey periods relative to the spring and summer survey periods is likely a result of the larger overall emergent area of sandbars during the fall period that increased the potential for overlap between polygons. Changes in sandbar area between seasonal survey periods, when measured from collocated sandbar pairs, were similar to the seasonal differences observed for the larger population of sandbars. Changes in sandbar area measured at the individual sandbar level between the spring and summer survey periods generally were net erosional. Median change in sandbar area from spring to summer was greatest for island-attached sandbars, which decreased in area (fig. 7A). Mid-channel sandbar pairs had a median decrease of 4.3 acres between spring and summer survey periods. Bankattached sandbars had the widest range in responses between spring and summer, with most bars eroding, but some bars undergoing net expansion of up to 1.9 acres (fig. $7 A$ ). Sandbar area expanded between the summer and fall survey periods at most collocated sandbar pairs; however, this expansion is interpreted by the authors to be a consequence of the 
lower flows during the fall measurement period (fig. $7 B$; table 1). In contrast, comparisons between the spring and fall survey periods still indicated net erosion for most bank- and island-attached sandbars, indicating the erosion was of large enough magnitude to overpower the effect of the lower flows on emergent area at these types of sandbars (fig. 7C). Differences in sandbar area among spring-tofall data pairs indicated that 11 mid-channel sandbars expanded by a median value of 1.5 acres (fig. $7 C$ ).

\section{Seasonal and Longitudinal Changes in Emergent Sandbar Height}

A comparison of cumulative frequency distributions of measured sandbar height values between survey periods indicated that the high platform of surveyed sandbars was much higher during the spring survey period than during the subsequent summer and fall survey periods (fig. 8). Median measured sandbar height decreased from about $4.5 \mathrm{ft}$ to $3.0 \mathrm{ft}$ (height indexed to discharge of $4,000 \mathrm{ft}^{3} / \mathrm{s}$ ) between the spring and summer survey periods. During the spring survey period, most measured heights were between 3.5 and $5.5 \mathrm{ft}$, whereas, during the summer and fall survey periods, most measured heights were between 2.0 and $5.0 \mathrm{ft}$. Cumulative frequency distribution curves also indicated that measured sandbar heights were similar between the summer and fall survey periods, which was not unexpected because no high-magnitude discharges occurred between those surveys (maximum daily mean discharge was less than $15,000 \mathrm{ft}^{3} / \mathrm{s}$; fig. 2). Median sandbar height measured during the summer survey period was about $3.0 \mathrm{ft}$, and was about $3.2 \mathrm{ft}$ during the fall survey period (fig. 8). Although this difference would indicate an increase in bar height, quality-control data (described in the "Quality Control" section of this report) indicated that this difference is within the range of expected measurement uncertainty, and this difference in medians was one of the largest differences between the summer and fall surveys' cumulative frequency distributions (fig. 8).

The longitudinal distribution of sandbar heights by survey period indicated that, although sandbar height decreased between the spring survey period and subsequent survey periods, the general longitudinal pattern and trend of sandbar heights was similar across periods (fig. 9). Sandbar heights tended to follow a wavy longitudinal pattern whereby certain reaches consistently had more abundant and higher sandbars, and others had fewer, lower sandbars. LOESS lines fit to sandbar heights indicated that sandbar heights generally trended upward, if only slightly, in the downstream direction, although the significance of this trend was not tested. Large sandbars (sandbars with emergent areas larger than 2 acres) tended to be more abundant and higher between State Highway 50 and the Cedar Creek area, and lower and less abundant in a 3-mi reach immediately upstream from State Highway 50 and in the reaches near river miles 7-12 (fig. 9). Longitudinal patterns in sandbar height did not show a distinct covariation with other channel morphometric characteristics, although higher channel-sinuosity values tended to be weakly spatially correlated with more dense clusters of emergent sandbars, and unvegetated, active-channel width tended to trend slightly downward along the study segment as sandbar height tended to trend slightly upward (fig. $9 D$ ).

Median and maximum measured sandbar height values for larger sandbars indicated that the high platform on sandbars was between 0.5 and $2.0 \mathrm{ft}$ higher during the spring survey period than during the subsequent summer and fall survey periods. Bank-attached and mid-channel sandbars generally had the greatest group median height value (median of all sandbar-median values from all measured sandbars within each seasonal survey) and the greatest group median of maximum height value (median of all sandbar-maximum 
A. Sandbar heights measured during spring survey period
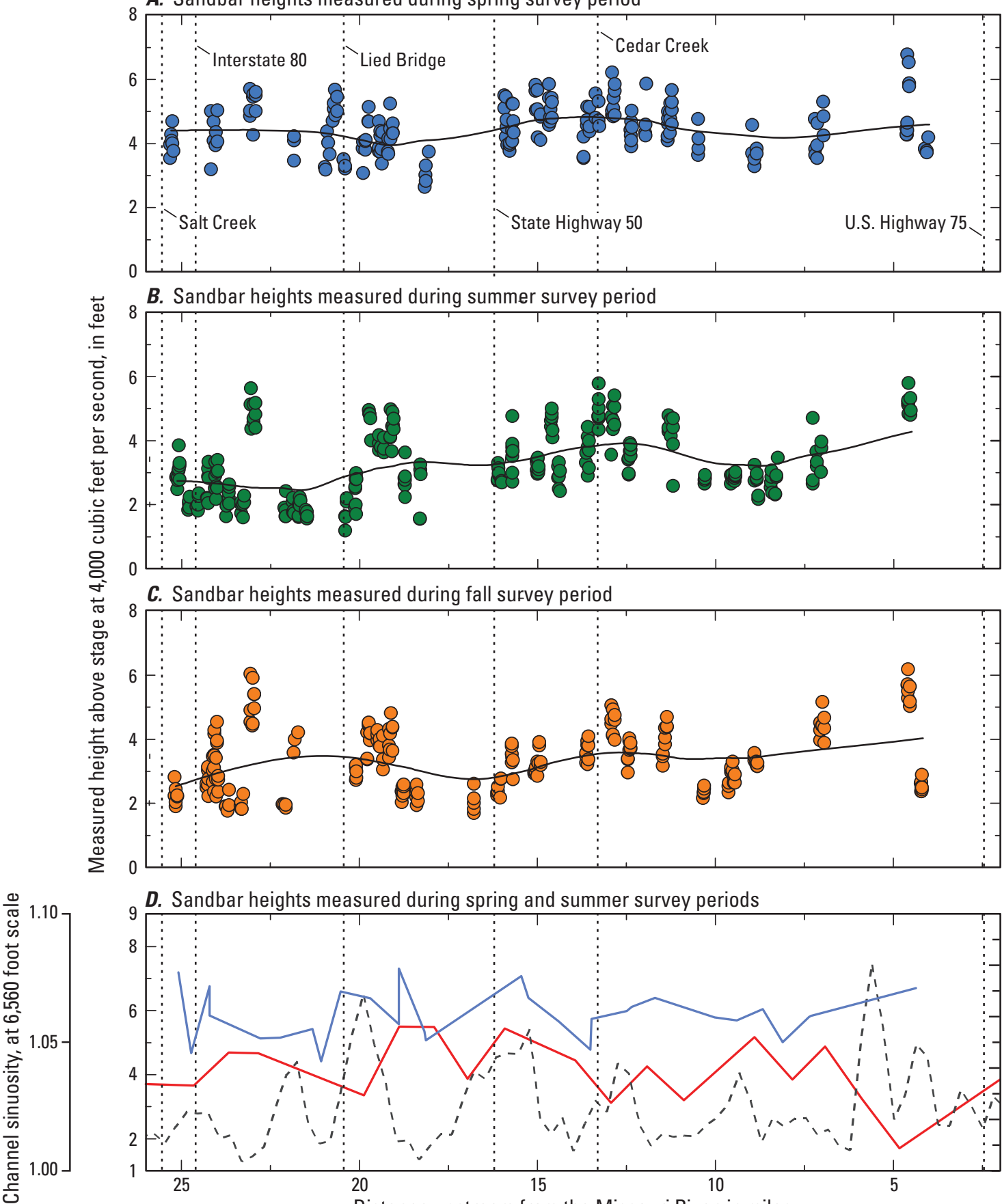

D. Sandbar heights measured during spring and summer survey periods

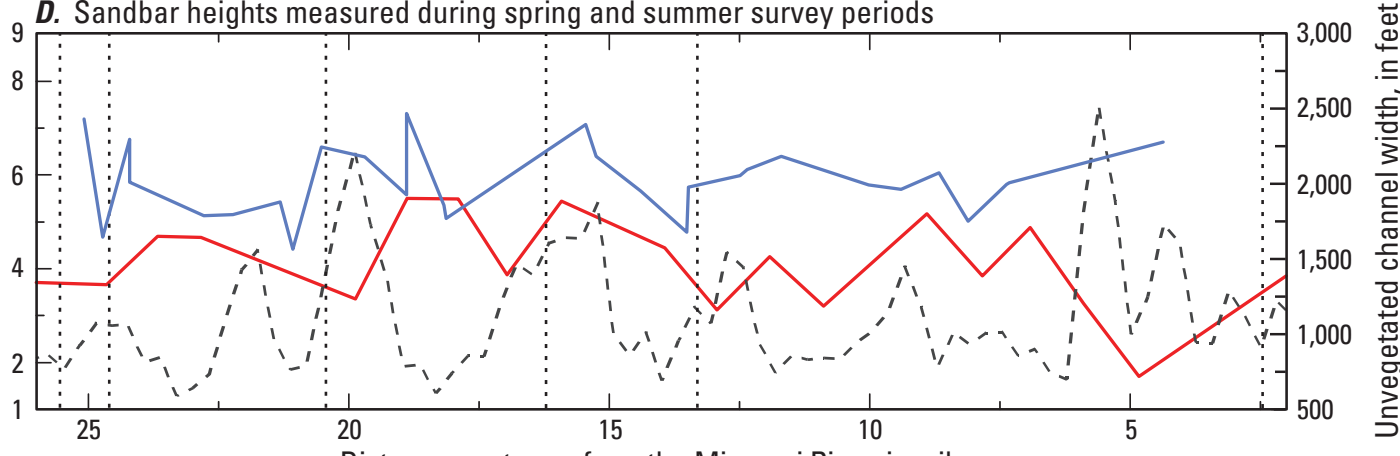

EXPLANATION

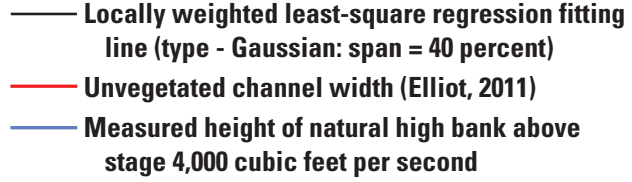
- - - - Sinuosity of river channel measured at 6,500 foot interval (Elliot and others, 2009)
..... Location of major feature along river channel centerline
$\bigcirc$ Measured sandbar height

Figure 9. Longitudinal distributions of measured sandbar heights from three survey periods in 2011 and river-channel morphometric characteristics, lower Platte River, Nebraska: $(A)$ sandbar heights measured during the spring survey period; $(B)$ sandbar heights measured during the summer survey period; $(C)$ sandbar heights measured during the fall survey period; and $(D)$ bank heights measured during the spring and summer survey periods, channel sinuosity, and unvegetated channel width. Channel sinuosity and unvegetated channel width are from Elliot and others (2009) and Elliot (2011), respectively. 


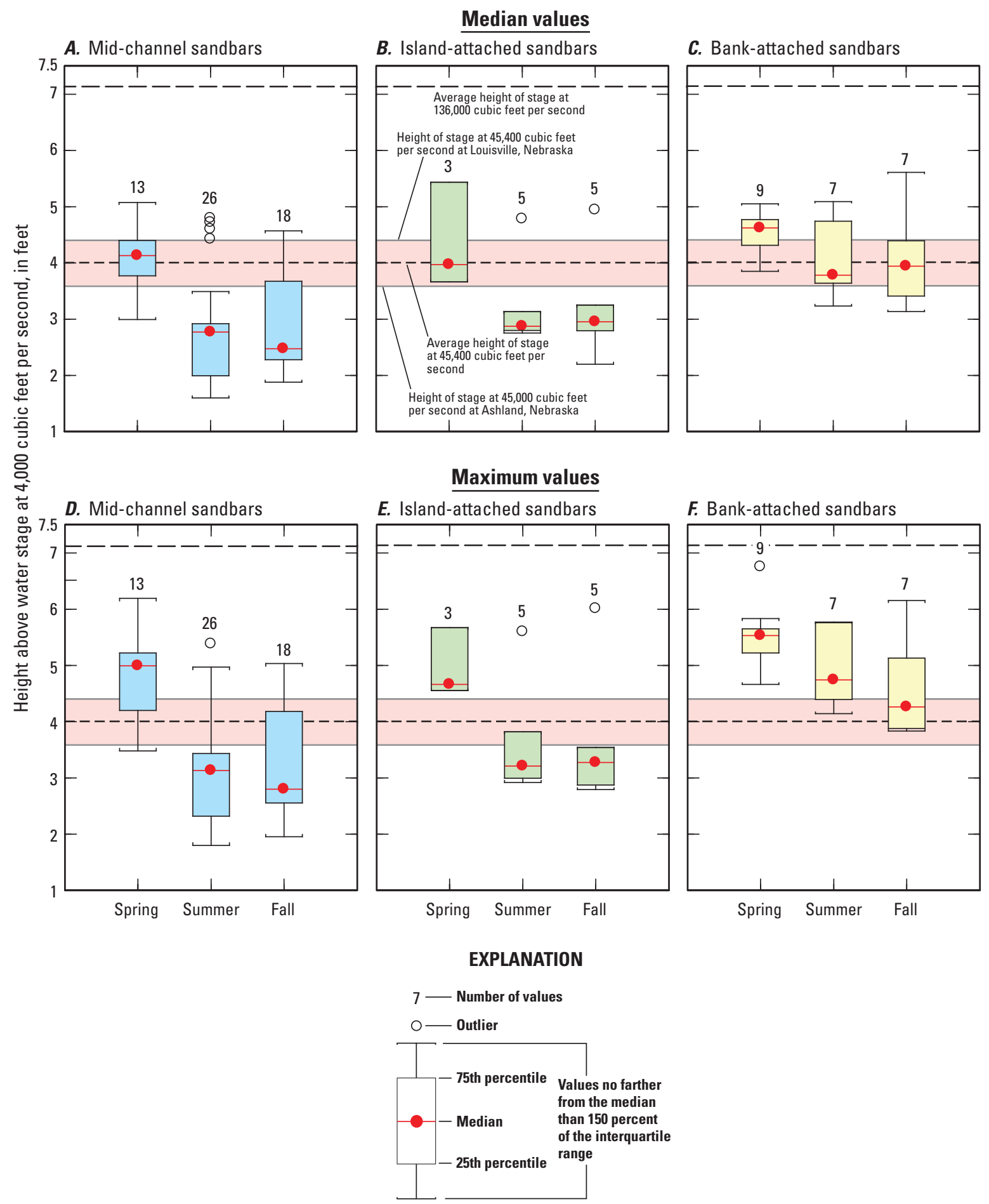

Figure 10. Frequency distributions of measured sandbar heights above river stage at 4,000 cubic feet per second for three survey periods and different bar types, lower Platte River, Nebraska, 2011: $(A-C)$ median measured sandbar heights, and (D-F) maximum measured sandbar heights.

values from all measured sandbars within each seasonal survey) across all seasons (fig. 10). The group-median heights for all sandbar types measured during the spring survey period indicated that the high platform of most sandbars was about 2-3 ft lower than the estimated stage of the 2010 instantaneous maximum discharge of $136,000 \mathrm{ft}^{3} / \mathrm{s}$, and group medians of maximum heights were between 1.5 and $2.5 \mathrm{ft}$ lower than the stage at this discharge (fig. 10). Group-median heights for mid-channel and island-attached sandbars measured in the spring were well within the range of estimated stages of the 2011 instantaneous maximum discharge of $45,400 \mathrm{ft}^{3} / \mathrm{s}$ (fig. 10). The group-median height of bank-attached sandbars 
Table 3. Summary statistics of differences between measured median and maximum sandbar heights and results of Wilcoxon signed-rank comparison tests between survey periods at collocated sandbar pairs, lower Platte River, Nebraska, 2011.

[Summary statistics of paired-ranked differences, differences between indicated statistic summarizing measured heights on collocated sandbar pairs between seasons; $p$-values, probability that central value of difference between data pairs is 0 at 95 -percent confidence level]

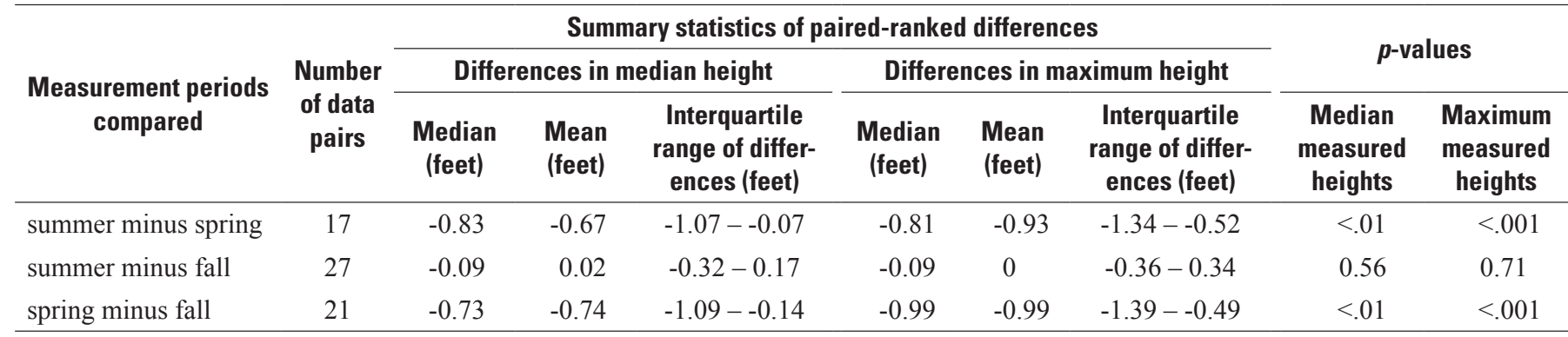

measured in the spring was higher than the estimated stages of the 2011 peak flow. Maximum measured heights from the spring survey, including the group-median of maximums for all sandbar types, generally were higher than the estimated stages of the 2011 peak flow, indicating that at least small parts of many sandbars were not inundated. However, the decrease in median and maximum measured heights following that latespring peak flow indicated that bar heights were often lowered, likely by lateral or downstream erosion. With the exception of bank-attached sandbars, group-median and group-median of maximum measured sandbar heights generally were similar between the summer and fall survey periods (fig. 10).

A comparison among seasonal survey periods of ranked differences between collocated sandbar pairs further confirms that a lowering of sandbar heights followed the spring survey period. Median values of differences in sandbar-median and -maximum height among collocated sandbar pairs between the spring and summer survey periods indicated decreases of 0.83 and $0.81 \mathrm{ft}$, respectively (table 3). Differences in the same statistics for sandbar pairs compared between spring and fall survey periods indicated decreases of 0.73 and $0.99 \mathrm{ft}$, respectively; and between the summer and fall survey periods indicated a decrease of $0.09 \mathrm{ft}$, for each statistic. The $p$-values resulting from Wilcoxon signed-rank tests of seasonal data pairs from collocated sandbars indicated that the differences in median and maximum heights between the spring and summer survey seasons and between the spring and fall survey seasons were significant at the 95-percent confidence level (table 3).

One of the primary aims of the study was to characterize the height of sandbars relative to the stage of formative flows. Because of the rarity of the 2010 instantaneous peak discharge, characterizing the height of sandbars formed by it was of particular importance. Sandbar height measurements for this study were referenced to the stage of the Platte River at nearby gages at a discharge rate of $4,000 \mathrm{ft}^{3} / \mathrm{s}$. The average stage height difference between $4,000 \mathrm{ft}^{3} / \mathrm{s}$ and the stage at $136,000 \mathrm{ft}^{3} / \mathrm{s}$ (the magnitude of the instantaneous peak discharge in 2010 measured at the Louisville gage) is $7.1 \mathrm{ft}$ (fig. 8). The frequency distribution of measured sandbar heights from high platforms for the spring survey indicates that 100 percent of the measured heights were less than
$6.8 \mathrm{ft}, 90$ percent of the measured heights were less than $5.5 \mathrm{ft}$, and more than half of measured heights were less than $4.5 \mathrm{ft}$ (fig. 8). These data indicate that, although the high platform of sandbars can approach the maximum stage of formative flow events, this height is rare, and more often the highest part of sandbars is $1-2 \mathrm{ft}$ less than the formative stage. Depending on which rating table is used (Ashland number 6 or Louisville rating number 14, M.J. Andersen, U.S. Geological Survey, written commun., 2011), between about 10 and 50 percent of measured heights from the spring survey would have been inundated by the 2011 high discharge of $45,400 \mathrm{ft}^{3} / \mathrm{s}$, a discharge 67 percent less than the $2010 \mathrm{flood}$. Using the rating from the Louisville gage, more than 98 percent of measured heights from the spring survey would have been inundated by a flow of about $85,000 \mathrm{ft}^{3} / \mathrm{s}$, a discharge about 38 percent less than the 2011 flood.

The methods of data collection, data analysis, and presentation for the study were different enough from previous reports of sandbar heights (Ziewitz and others, 1992; Brown and Jorgensen, 2008; Brown and Jorgensen, 2009) that direct comparison of measured bar heights is difficult. Nevertheless, sandbar height data in Ziewitz and others (1992) and Brown and Jorgensen (2008) were collected shortly after low-frequency, high-magnitude discharge events, and their measurements of sandbar height indicate a consistent pattern of 1 and $3 \mathrm{ft}$ of space, respectively, between the estimated stages of those floods and reported sandbar heights. The peak discharge of the LPR in 1988, when Ziewitz and others (1992) surveyed sandbar heights in the LPR, had a magnitude of only $24,000 \mathrm{ft}^{3} / \mathrm{s}$ at the Louisville gage, but the peak discharge in 1987 was $103,000 \mathrm{ft}^{3} / \mathrm{s}$. The heights of sandbars reported by Ziewitz and others (1992) ranged from a mean-of-maximums of $2.2 \mathrm{ft}$ to a maximum-of-maximums of $5.5 \mathrm{ft}$, which spans nearly 90 percent of the range of heights measured during the spring survey for the study described in this report (fig. 8). Using the latest stage-discharge rating table (no. 14) from the Louisville gage as an approximation of the stagechange ranges in 1988, mean-of-maximum sandbar heights would have been about $0.66 \mathrm{ft}$ lower than the stage of the river at $24,000 \mathrm{ft}^{3} / \mathrm{s}$, but maximum-of-maximum reported heights would have been more than $2.6 \mathrm{ft}$ higher, suggesting 


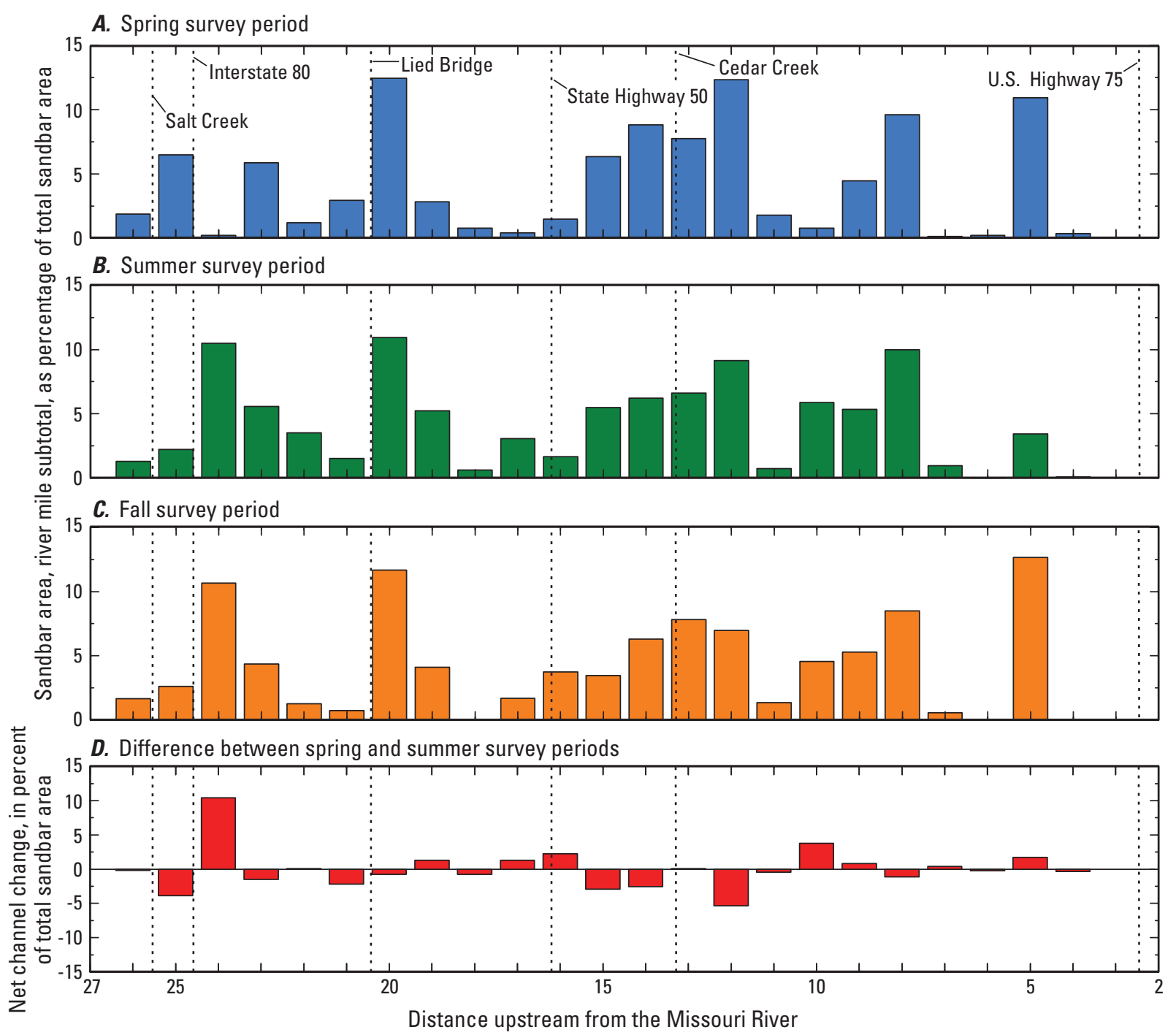

Figure 11. Longitudinal distribution of emergent sandbar area for three survey periods and net change in emergent sandbar area between river miles 3 and 26, lower Platte River, Nebraska, 2011: $(A)$ spring survey period, $(B)$ summer survey period, $(C)$ fall survey period, and $(D)$ difference in percent of total sandbar area by river mile between spring and fall survey periods.

that sandbars observed by Ziewitz and others (1992) in 1988 likely were formed by the 1987 flood. Mean-of-maximum and maximum-of-maximum measured heights reported by Ziewitz and others (1992) would have been about 4.2 and $0.9 \mathrm{ft}$ lower, respectively, than the estimated stage of the formative discharge of $103,000 \mathrm{ft}^{3} / \mathrm{s}$.

The peak discharge in 2008, just prior to when Brown and Jorgensen (2008) surveyed sandbar heights in the LPR, was $96,600 \mathrm{ft}^{3} / \mathrm{s}$. In that part of the LPR that coincides with the study area described in this report, Brown and Jorgensen (2008) reported maximum sandbar heights between 0.5 and $2.8 \mathrm{ft}$ higher than the stage during the late summer discharge of $19,500 \mathrm{ft}^{3} / \mathrm{s}$, which, based on the latest rating table from the Louisville gage, indicates that bar heights formed by the 2008 flood were about 1.1-3.4 ft lower than the maximum stage of the flood. Therefore, data from the study described in this report and data reported by Ziewitz and others (1992) and Brown and Jorgensen (2008) indicate that sandbar heights formed by a low-frequency discharge event are subject to subsequent inundation by discharges as much as $25-80$ percent of their respective formative event.

\section{Seasonal Changes in Longitudinal Distribution of Emergent Sandbars}

Although the magnitude of total emergent sandbar area varied between surveys, the streamwise distribution of emergent sandbar area did not change substantially among the three survey periods. A comparison of plots of the longitudinal distribution of sandbar area, normalized as percentage of total sandbar area, indicated that river reaches with abundant emergent sandbar area tended to be the same across the three survey periods (fig. 11). The surveyed sandbar area ranged 
from 0 to 12.7 percent of the total study-segment area within an individual river mile, but multimile reaches where each individual river mile had at least 5 percent of total emergent bar area tended to cluster in the same locations during each survey season. In particular, river miles 8 and 20 , and those river miles near Cedar Creek tended consistently to have an abundance of emergent sandbar area. Between spring and fall survey periods, the median change in the fraction of total emergent sandbar area, tabulated by river mile, was a decrease of only 0.21 percentage point, and the interquartile range of such net changes was from -1.32 to 1.06 percentage points. The largest shift in fraction of total emergent area was for river mile 24 , where the percentage of total emergent sandbar area increased by about 10 percentage points between the spring and fall survey periods (fig. 11D). The large shift in percentage of total sandbar area resulted from a combination of additional emergent sandbar area created by deposition during the high flows of May and June 2011 and a downstream shift in the areal centroid of one large sandbar, which moved the accounting of its bar area into river mile 24 from river mile 25.

When compared among collocated sandbar pairs, shifts in sandbar locations, measured as shifts in sandbar areal centroid between survey seasons, indicated that sandbars tended to erode or deform from upstream to downstream, but overall shifts in center of area tended to be small. Median streamwise shift in areal centroid among sandbar data pairs, between the spring and summer survey seasons, ranged from -0.05 to $-0.01 \mathrm{mi}$ (negative value means downstream shift), and was greatest for mid-channel sandbars (fig. 12A). Despite substantial increases in emergent sandbar area, shifts in sandbar areal centroid among data pairs between the summer and fall survey seasons had median values ranging from -0.02 to $-0.003 \mathrm{mi}$, and had narrower interquartile ranges than the corresponding spring-to-summer shifts. Mid-channel sandbar pairs had the most variability in shifts between summer and fall survey periods (fig. 12B). The small median values of net shifts in sandbar areal centroid among data pairs between the spring and fall surveys (range of -0.02 to $0.03 \mathrm{mi}$ ) were dwarfed by the variability of shift distances within each bar type (fig. 12C).

The difference between the spring-fall and summer-fall shifts in areal centroid (fig. 12) indicates that the high flows that occurred between the spring and summer survey periods largely shifted sandbar areal centroids downstream. The increase in number and magnitude of positive (upstream) shifts between the spring and fall survey periods indicates that more of the submerged part of the sandbar's mass was near the upstream end of some sandbars. The downstream shift in sandbar areal centroid between spring and summer surveys was, in some cases, offset by an upstream shift between summer and 
Table 4. Summary of replicate surveys of sandbar area measured using differential-grade global-positioning system, lower Platte River, Nebraska, 2011.

[Relative percent difference, percent difference between original and replicate surveyed sandbar area, obtained by by subtracting the quotient of original and replicate measured areas from 1 and multiplying by 100; $p$-value, probability that central value of differences between data pairs is equal to 0 , at 95 -percent confidence level, from Wilcoxon signed-rank test; No., number; na, not applicable]

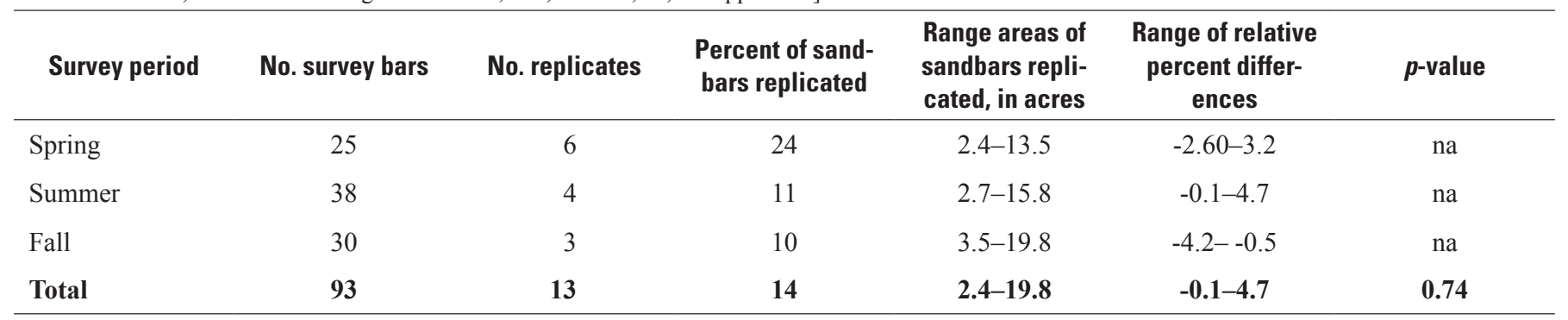

fall. The net shift upstream was most common for mid-channel sandbars and could indicate that the high flows of 2011 did not simply erode the upstream ends of these bars and transport the sand away; rather, for some bars, these areas were reworked, causing net lowering and subsequent deposition of additional sand mass along the upstream margins of sandbars. The small number of bars in each sandbar type category limits the strength of evidence for this process inferred from the 2011 surveys alone.

\section{Quality Control}

Sandbar location and geometry can be quantified in many ways, using varied methods and many associated measures. Each measure is sensitive to method and instrument limitations of precision and accuracy, as well as operator error or bias. Because the rapid-assessment data-collection methods developed and used for this study are new (although they are influenced by methods reported elsewhere), some characterization of the nature of uncertainties and sensitivity of each measure is required to assess the quality and repeatability of the data collected using these methods.

\section{Sandbar Area}

Replicate DGPS surveys of sandbar area were performed on 13 sandbars across much of the range of sandbar sizes present during the survey periods, and the bars where surveys were replicated constituted 14 percent of all measured sandbars (table 4). The mean relative difference in sandbar area between original and replicate DGPS measurements was 0.62 percent of the original measurement, and all replicate measurements were within 5 percent of the original survey (fig. 13). A comparison of the percent difference between original and replicate measurements of sandbar area with sandbar size indicated that differences in area generally were both positive and negative, and that magnitudes were evenly distributed across the range of sandbar sizes measured (fig. 13). Results ( $p$-values) from the Wilcoxon signed-rank test of replicate pairs indicated that the central value of differences between paired areas did not differ significantly from zero at the 95-percent confidence level (table 4).

Differences in emergent sandbar area between measurements made with the higher-precision laser total station and those made with the handheld DGPS method indicated that the overall size of areas obtained using the DGPS method is likely within 5 percent of the overall size of areas obtained using the laser total-station method (table 5). Although comparisons can be made for only four sandbars, differences between sandbar areas obtained using the laser total station and DGPS method were both positive and negative, and did not appear to be affected by the size of the sandbar. The areas delineated in the total-station survey had less detail along the sandbar boundary, but the close agreement between the magnitudes of sandbar area obtained using the two methods indicates that the DGPS

Table 5. Differences between sandbar areas measured with differential-grade global-positioning system and using a totalstation laser-surveying instrument, lower Platte River, Nebraska, 2011.

[Relative percent difference, percent difference between areas measured using total station and DGPS survey methods, obtained by subtracting the quotient of total station and DGPS measured areas from 1 and multiplying by 100; QC, quality-control; DGPS, differential-grade-global positioning system]

\begin{tabular}{cccc}
\hline QC bar & $\begin{array}{c}\text { Area obtained } \\
\text { from DGPS } \\
\text { (acres) }\end{array}$ & $\begin{array}{c}\text { Area obtained } \\
\text { from total-station } \\
\text { survey (acres) }\end{array}$ & $\begin{array}{c}\text { Relative } \\
\text { difference } \\
\text { (percent) }\end{array}$ \\
\hline 1 & 3.4 & 3.6 & -4.7 \\
2 & 8.7 & 8.4 & 3.0 \\
3 & 19.0 & 19.7 & -3.5 \\
4 & 29.2 & 28.9 & 1.1 \\
\hline
\end{tabular}




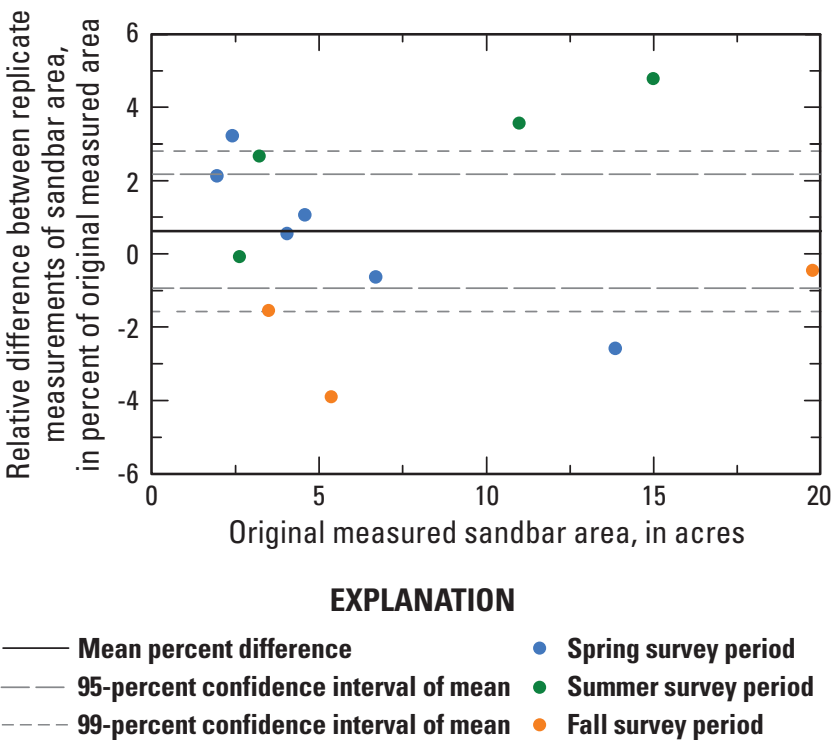

Figure 13. Differences between original and replicate differential-grade global-positioning-system surveys of sandbar area, as percentage of original sandbar area, relative to sandbar size, lower Platte River, Nebraska, 2011.

method likely is adequate for obtaining estimates of sandbar emergent area within 5 percent of the actual size (table 5).

\section{Sandbar Height}

Original and replicate spot measurements of sandbar height were paired based on their rank within the sample datasets. Ranked original and replicate sandbar height measurements surveyed with the rapid-assessment method indicated that slight differences in the placement of the survey grid did not result in substantial differences in the range of heights surveyed. Ranked original and replicate data pairs show strong agreement (fig. 14A); mean difference between ranked original and replicate spot measurements of sandbar height was $-0.002 \mathrm{ft}$, and ranged from -1.15 to $0.48 \mathrm{ft}$ (fig. $14 B$ ). The 95-percent confidence interval of mean difference in ranked spot measurements of sandbar height was -0.07 to 0.07 , indicating a range of uncertainty of mean difference in replicated sandbar height of about $0.20 \mathrm{ft}$ at high levels of statistical confidence. Although higher sandbars tended to also be larger sandbars, and, therefore, potentially subject to greater uncertainty, no relation of bias or imprecision in sandbar height with respect to sandbar size was apparent in scatter plots of differences between original and replicate heights (fig. 14B). Results from Wilcoxon signed-rank tests of 11 replicate pairs of sandbar-median and -maximum measured heights indicated that differences between data pairs are insignificant at the 95-percent confidence level (table 6).

A comparison of measurements of sandbar and nest heights relative to cumulative topographic distributions generated from the more detailed total-station surveys indicated that technicians could adequately identify and measure the highest part (high platform) of a sandbar. Spot measurements of
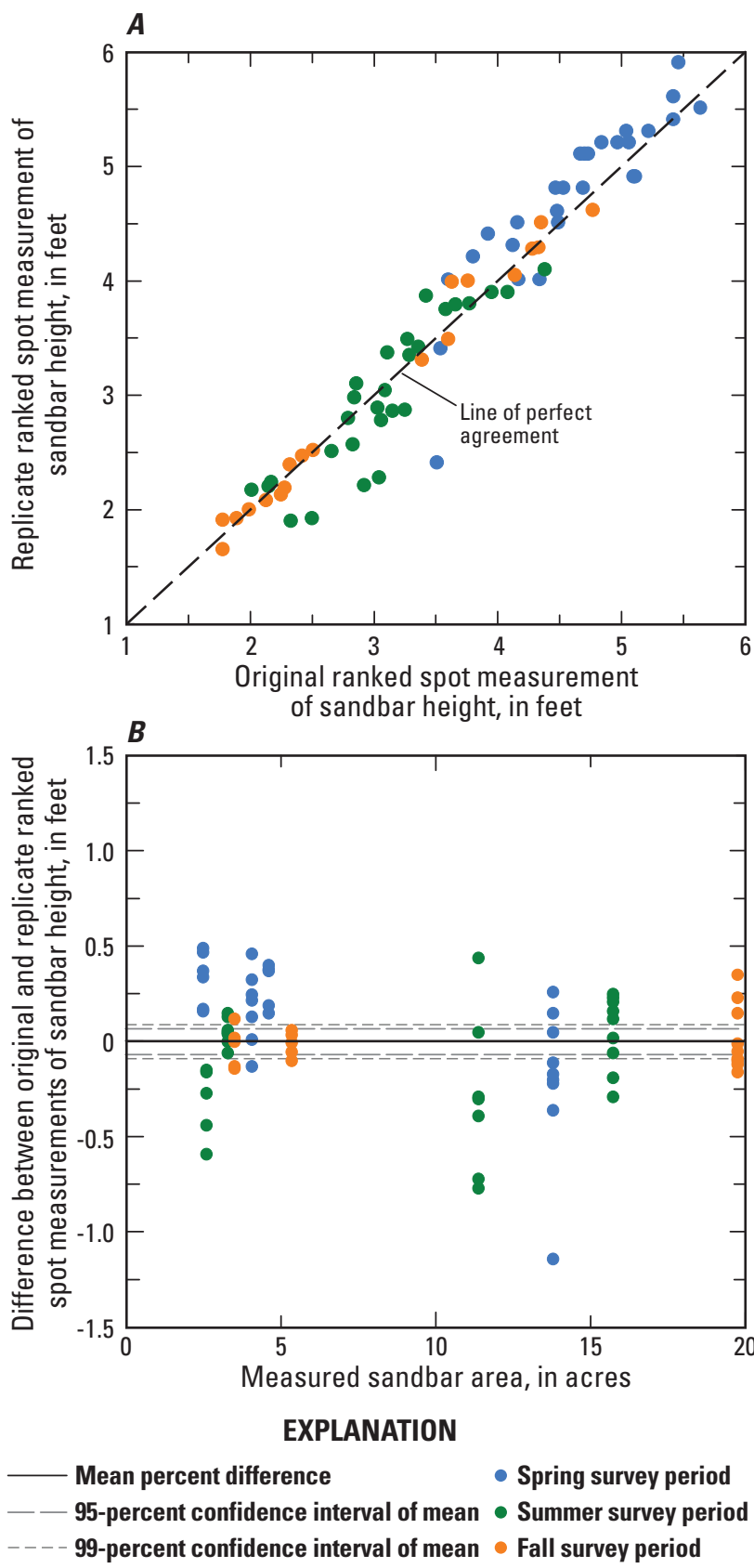

Figure 14. Quality-control data associated with spot measurements of sandbar height, lower Platte River, Nebraska, 2011: $(A)$ original versus replicate ranked spot measurements of sandbar height, and $(B)$ differences between ranked original and replicate spot measurements of sandbar height relative to sandbar area.

sandbar height generated using the rapid-assessment method ranged from the 51st to the 98th percentile of sandbar height frequency distributions (fig. 15), with sandbar-median and -maximum values of the high-platform height between the 73rd and 93rd, and the 95th and 98th percentiles of sandbar heights, respectively. At the two sandbars where several nest heights were measured, individual nest heights ranged between the 62nd and 99th percentile of sandbar heights, 


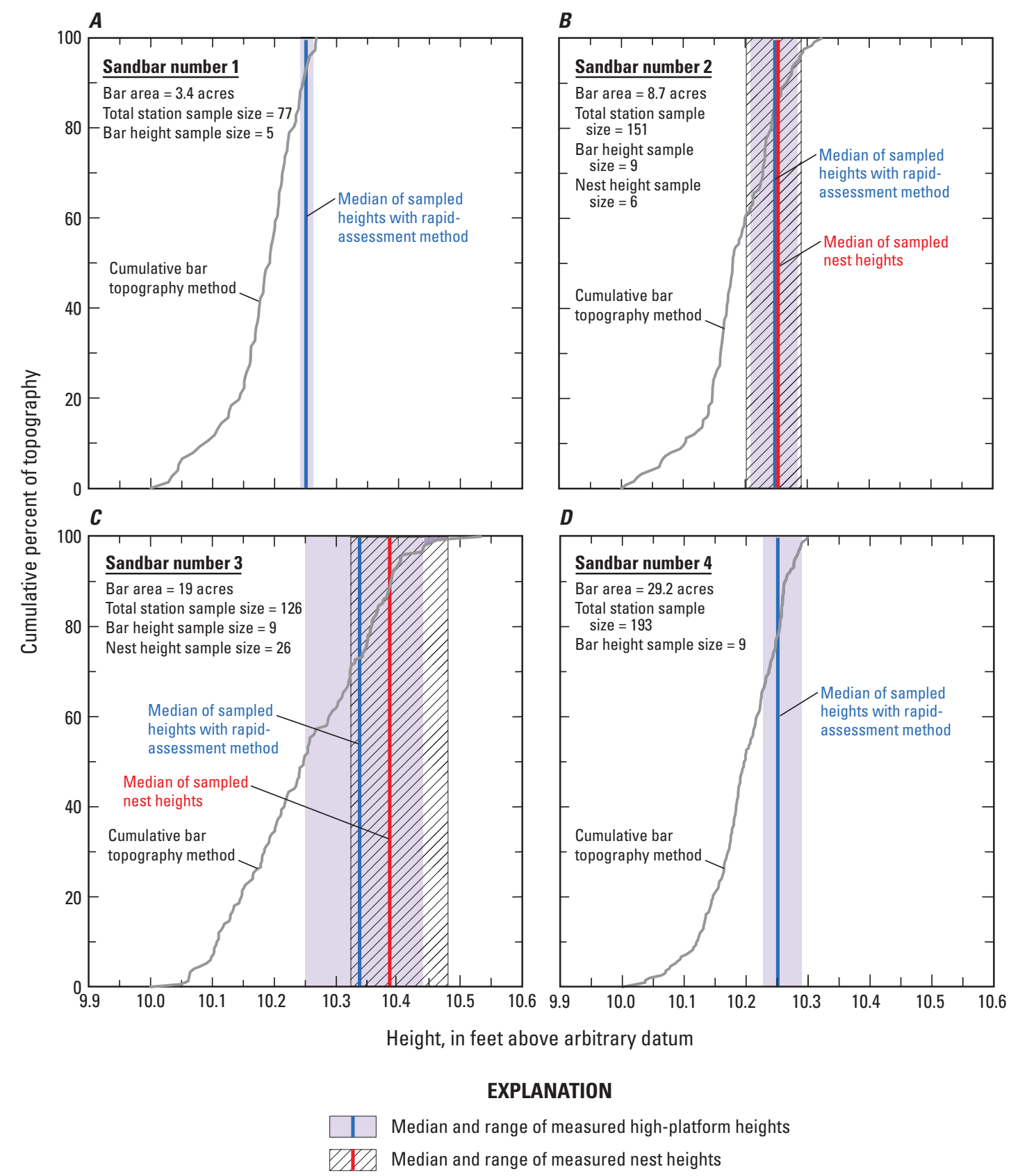

Figure 15. Cumulative frequency distribution of sandbar topography, medians, and ranges of spot measurements of sandbar height using the rapid-assessment survey method, and medians and ranges of heights of previously used tern nests on four sandbars of varying size, lower Platte River, Nebraska, 2011: $(A)$ sandbar number 1, 3.4 acres; $(B)$ sandbar number 2, 8.7 acres; $(C)$ sandbar number 3, 19 acres; and $(D)$ sandbar number 4, 29.9 acres.

and median nest heights ranged between the 86th and 89th percentiles (fig. 15). Although nest heights only were measured at two sandbars, a comparison of the range of highplatform heights obtained by the rapid-assessment method and the range of surveyed heights of nests indicated that at least the highest one-half of measured high-platform heights overlapped with and adequately represented the range of nest heights observed in 2011.

\section{Limitations of the Study}

The emergent sandbar data represent only three seasons within a single calendar year and sandbar configurations chiefly affected by, at most, two high-discharge events (in 2010 and 2011). Without additional data collected over several more years and several more high-flow events, it is unclear whether the results of this study show long- or short-term sandbar dynamics; therefore, the time scale over which they can be applied is similarly uncertain. Likewise, the geometries 
Table 6. Summary statistics of differences in measured sandbar height and results of Wilcoxon signed-rank comparison tests between replicate surveys using laser-leveling method, lower Platte River, Nebraska, 2011.

[QC, quality-control; $p$-value, probability that central values of differences between data pairs is equal to 0 at 95 -percent confidence level, from Wilcoxon signed-rank test]

\begin{tabular}{lcccc}
\hline & \multicolumn{3}{c}{$\begin{array}{c}\text { Summary statistics of differences in height } \\
\text { between replicates }\end{array}$} \\
\cline { 2 - 5 } $\begin{array}{c}\text { Sandbar } \\
\text { height sta- } \\
\text { tistic }\end{array}$ & $\begin{array}{c}\text { Number } \\
\text { of QC data } \\
\text { pairs }\end{array}$ & $\begin{array}{c}\text { Mean } \\
\text { (feet) }\end{array}$ & $\begin{array}{c}\text { Interquartile } \\
\text { range of } \\
\text { differences } \\
\text { (feet) }\end{array}$ & p-value \\
\hline Median & 11 & 0.03 & $-0.06-0.15$ & 0.46 \\
Maximum & 11 & -0.14 & $-0.17-0.22$ & 0.96 \\
\hline
\end{tabular}

and locations of sandbars present during the spring survey period were measured more than 9 months after the 2010 instantaneous maximum discharge of $136,000 \mathrm{ft}^{3} / \mathrm{s}$ occurred. With the information now available, we cannot know with absolute certainty the extent to which the geometries and spatial distributions of the emergent sandbars measured during the spring survey period differed from their configuration immediately after the 2010 peak discharge. A comparison of the summer and fall survey period datasets from this study, however, indicates that the geometry and distribution of sandbars in fall 2010 likely were similar to the configuration immediately after the June 2010 peak discharge. Flows were generally low and stable for much of the intervening period, although a moderate rise owing to ice melt occurred a little more than a month prior to the spring survey (fig. 2). Therefore, no hydrologic evidence exists to indicate that a substantial scour or depositional event occurred. Parts of the highest sandbars measured during the spring survey period were higher than the stages of the spring and summer rises in 2011, and, therefore, were formed by a flow event with a magnitude greater than $45,400 \mathrm{ft}^{3} / \mathrm{s}$.

\section{Implications for Ecology and Further Geomorphic Study}

The longitudinal patterns of emergent sandbar areas and heights in this study indicate that certain reaches of the LPR are more conducive to deposition of extensive areas of higher sandbars, and that these locations apparently did not change much after one modest and two moderately large spring river rises partially inundated, reworked, and redeposited the sandbars. Even after the additional emergence of sandbars because of the lower-magnitude flows during the fall survey, the spatial distribution of emergent area (at the scale of river-mile intervals) did not change substantially.

Although analysis of linkages between longitudinal characteristics of sandbar geometries and tern and plover nesting locations was outside of the scope of the pilot study described in this report, the two sandbars with confirmed tern nesting colonies in 2011 (within the study area) were located across from the Cedar Creek development, an area of the LPR where the emergent sandbar area was abundant (fig. 11) and sandbars generally were higher than elsewhere in the study segment (fig. 9). Colonies of nesting terns, although not necessarily producing fledges, have been observed on sandbars near Cedar Creek every year since at least 2008 (Brown and Jorgensen, 2008; Brown and Jorgensen; 2009, Brown and Jorgensen, 2010; Brown and others, 2011b). As described in "Seasonal and Longitudinal Changes in Emergent Sandbar Height," 2008 also was a year when a larger-than-average annual flood created abundant emergent sandbar habitat throughout the LPR (Brown and Jorgensen, 2008), and the area around Cedar Creek was likely a locus of deposition in that year. The fact that habitat created in 2008 persisted or was replenished during the high discharge of 2010 further indicates that the Cedar Creek reach may have morphological conditions that favor either persistent habitat (lower sandbar erosion rates) or consistent deposition (higher deposition rates per unit of discharge).

Data from this study and evidence from previous studies indicate that longitudinal patterns and trends of emergent sandbar geometry exist in the LPR. The reporting of such patterns in multiple studies indicates a potential to isolate combinations of morphologic, hydrologic, and hydraulic conditions tending to favor deposition or persistence of midchannel sandbars with characteristic geometries and surrounding environments that are frequently selected for nesting by tern and plovers in the LPR. For example, recent studies by Elliott (2011) and Jorgensen and others (2012) have indicated that terns and plovers tend to nest in reaches with wider active (non-vegetated) channels, but too much width also may be a limitation. Although channel width may create favorable nesting conditions through purely ecological mechanisms (by limiting predator access, for example), changes in channel width, particularly channel expansion zones, long have been shown to create favorable conditions for macroform deposition (Leopold and Wolman, 1957; Mosely, 1976), whereby bedload sediment passes through a channel constriction, and deposits when tractive forces are reduced owing to flow expansion (Ashmore, 1993; Ashworth, 1996; Ashworth and others, 2000). Within this morphological framework, bedload sediment transport potential can be scaled to channel width using a unit-stream-power equation (Bagnold, 1977):

$$
\Omega=(\gamma Q S) / w
$$

where

$\Omega \quad$ is unit stream power in units of pounds per foot per second,

$\gamma \quad$ is the specific weight of water (62 pounds per cubic foot $\left.\left[\mathrm{lb} / \mathrm{ft}^{3}\right]\right)$,

$Q \quad$ is river discharge in cubic feet per second,

$S \quad$ is water surface slope (dimensionless), and

$w \quad$ is wetted channel width in units of $\mathrm{ft}$. 
Costa and O'Conner (1995) suggested a time integration of stream power over the period of a formative flow event that can be used as an indicator of geomorphic effectiveness:

$$
\Omega_{\text {tot }}=\int \Omega d t
$$

where

$$
\begin{aligned}
& \Omega_{\text {tot }} \text { is total unit stream power, and } \\
& d t \text { is the incremental time period of the flow } \\
& \text { event. }
\end{aligned}
$$

Applying total unit stream power in a spatial context, areas of maximum total unit stream power would be the narrowest reaches (bottlenecks), while areas of minimal total unit stream power would be the widest reaches. Therefore, midchannel sandbars with geometries that favor both selection for nesting and minimal probability of nest inundation may be the result of a relatively constrained range of unit stream powers, or reach-scale changes in total unit stream power, such that enough tractive force is exerted to construct a high sandbar, but not so much that deposition is unlikely during formative events. Conversely, a reach that is very wide in unvegetated width would likely be a zone of deposition during flow recession of a formative event, but such reaches also would likely have relatively low total unit stream power, and consequently may not have the tractive force necessary to build sandbars to sufficient heights. Moreover, these "goldilocks" depositional zones of higher-quality, mid-channel sandbar habitat would likely shift over decade-to-century time-periods, as bottlenecks and expansion zones shift in a longitudinal manner.

These goldilocks zones are likely not the only locations where quality mid-channel sandbar habitat is formed. For example, Elliott and others (2009) suggested that reaches of higher-channel sinuosity also would likely have more potential for flow separation, and, therefore, would have a higher depositional potential. Within the study segment, reaches with greater channel sinuosity, such as the reach within the first mile downstream from the Lied Bridge (fig. 9), also had extensive areas of higher, larger, mid-channel sandbars; however, nesting was not documented in this reach in 2011.

With continued monitoring of sandbar dynamics, areas of the LPR that consistently produce habitat favored by nesting colonies of terns and plovers potentially could be quantified and identified (mapped). Such information would provide valuable information for planning and permitting of future river corridor development, infrastructure routing, and construction projects, as well as for constructing or restoring high-quality nesting habitats for terns and plovers in sand-bed rivers elsewhere on the Great Plains.

\section{Summary and Conclusions}

The lower Platte River (LPR) corridor provides important habitats for two State- and federally listed bird species: the interior least tern (terns; Sternula antillarum athallassos) and the piping plover (plovers; Charadrius melodus). The LPR, defined as the 103 miles (mi) of the Platte River between its confluence with the Loup River and its confluence with the Missouri River, has narrowed since the late-19th and early20th centuries, yet it partially retains many geomorphologic and hydrologic characteristics important to terns and plovers. Terns and plovers nest on the sandbars in the river and along shorelines at sand-and-gravel mine lakes on the adjacent valley floor. The need to balance continued economic, infrastructure, and resource development with the conservation of important physical and aquatic habitat resources requires increased understanding of the physical and biological dynamics of the LPR. Spatially and temporally rich datasets for emergent sandbar habitats are necessary to quantify emergent sandbar dynamics relative to hypothesized controls and stressors.

In cooperation with the Lower Platte South Natural Resources District, the U.S. Geological Survey initiated a pilot study of emergent sandbar dynamics along a 22-mi segment of the LPR downstream from its confluence with Salt Creek, near Ashland, Nebraska. The purposes of the study were to: (1) develop methods to rapidly assess sandbar geometries and locations in a wide, sand-bed river, and (2) apply and validate the method to assess emergent sandbar dynamics over three seasons in 2011. Of particular interest was an examination of the height of sandbars relative to the local stage of the formative discharge event, and how subsequent river discharges, of both large and small magnitude, alter sandbar geometries and abundance within the LPR. This report describes the methods developed and used to collect data associated with emergent sandbars, and the findings of the initial analyses of these data.

A "rapid-assessment" method was developed and used for the study, with the goal of characterizing the spatial distribution and habitat-relevant geometries of all sandbars along the study segment. Three primary measures were used to assess emergent sandbar dynamics in the study segment: sandbar area, sandbar height, and sandbar location. Data to derive these measures were collected during three, week-long survey periods in 2011: April 6-12, called the "spring survey;" July 26-August 2, called the "summer survey;" and October 31November 4, called the "fall survey." Emergent sandbars were grouped into one of three generalized types: (1) bank-attached, (2) island-attached, and (3) mid-channel.

The area of 68 sandbars, with a total estimated emergent area of 360 acres, was surveyed or estimated during the spring survey period. Mid-channel sandbars were the most abundant of the three measured sandbar classes, and ranged in emergent area from 1.9 to 22.5 acres. The few island-attached sandbars surveyed during the spring generally were large, ranging in emergent area from 6.7 to 18.9 acres. Bank-attached sandbars constituted about half of the total measured emergent sandbar area during the spring survey period, and had median areas of 13.8 acres, the largest of the three sandbar classes.

One hundred five sandbars, with a total estimated emergent area of 315 acres, were surveyed or estimated during the summer survey period. An apparent decrease in total emergent 
sandbar area occurred despite slightly lower daily discharges relative to the spring survey period, and primarily was the result of a decrease in the total emergent area of bank-attached sandbars. Mid-channel sandbars increased in total number and total emergent area, indicating that the intervening high flows not only dissected larger mid-channel bars into smaller bars, but also created many new emergent mid-channel sandbars.

Seventy-three sandbars, with a total estimated emergent area of 402 acres, were measured during the fall survey period. The increase in sandbar area occurred despite a net decrease in the total number of emergent sandbars, and was an effect of the lower average daily discharges during the fall survey period relative to the summer and spring survey periods. Much of the increase in emergent area occurred by means of an increase in the area of mid-channel sandbars larger than 2 acres, indicating that a substantial area of shallow-water habitats had surrounded the larger mid-channel sandbars, and this area emerged when discharges decreased.

There were 17 collocated sandbars common to the spring and summer survey periods, 27 collocated sandbars common to the summer and fall survey periods, and 21 collocated sandbars common to the spring and fall survey periods. Changes in sandbar area between seasonal survey periods, when measured for collocated sandbar pairs, were similar to the seasonal differences observed for the larger population of sandbars. Midchannel sandbar pairs had a median decrease in emergent area of 4.3 acres between spring and summer survey periods. Bank attached sandbar pairs had the widest range of areal change between spring and summer, with most bars eroding, but some bars undergoing net expansion of up to 1.9 acres. Comparisons between the spring and fall survey periods indicated net erosion for most bank- and island-attached sandbars, with sufficient erosion to overpower the effect of the lower discharges on emergent area at these types of sandbars.

A comparison among survey periods of cumulative frequency distributions of measured sandbar heights indicated that the high platform of sandbars was much higher during the spring survey period than during the subsequent summer and fall survey periods. Median measured sandbar height, indexed to the stage for a discharge of 4,000 cubic feet per second $\left(\mathrm{ft}^{3} / \mathrm{s}\right)$, decreased from about 4.5 to 3.0 feet (ft) between the spring and summer survey periods. During the spring survey period, most measured heights were between 3.5 and $5.5 \mathrm{ft}$, whereas, during the summer and fall survey periods, most measured heights were between 2.0 and $5.0 \mathrm{ft}$. Cumulative frequency distribution curves also indicated that sandbar heights were similar between the summer and fall survey periods, which was not unexpected because no high-magnitude discharges occurred between those surveys.

The longitudinal distribution of sandbar heights by survey period indicated that, although sandbar heights decreased between the spring survey period and subsequent survey periods, the general longitudinal pattern and trend of sandbar heights were similar across periods. Sandbar heights tended to follow a wavy longitudinal pattern whereby certain reaches had more abundant and higher sandbars, and others had fewer, lower sandbars. The locations of these reaches generally were the same across survey periods. Locally weighted least-squares regression lines fit to sandbar heights indicated that sandbar heights generally trended upward, if only slightly, in the downstream direction. Larger sandbars tended to be more abundant and higher between State Highway 50 and the Cedar Creek area, and lower and less abundant in the first $3 \mathrm{mi}$ upstream from State Highway 50.

Median and maximum measured sandbar heights indicated that the high platform on sandbars was between 0.5 and $2.0 \mathrm{ft}$ higher during the spring survey period than during the subsequent summer and fall survey periods. Bank-attached and mid-channel sandbars generally had the greatest groupmedian height and group-median of maximum height values across all seasons. Group-median heights for all sandbar types measured during the spring survey period indicated that the high-platform of most sandbars was about $2 \mathrm{ft}$ lower than the estimated stage of the 2010 peak discharge of $136,000 \mathrm{ft}^{3} / \mathrm{s}$, and group medians of maximum height values were between 1.5 and $2.5 \mathrm{ft}$ lower than this stage. Group-median heights for mid-channel and island-attached sandbars measured in the spring were well within the range of estimated stages of the 2011 high discharge of 45,400 $\mathrm{ft}^{3} / \mathrm{s}$, whereas the group-median height of bank-attached sandbars was higher than the estimated stages of the 2011 peak discharge. Maximum measured sandbar heights from the spring survey generally were higher than the estimated stages of the 2011 peak discharge, indicating that at least small parts of many sandbars were not inundated.

A comparison among seasonal survey periods of ranked differences between collocated sandbar pairs further confirms that a lowering of sandbar heights followed the spring survey period. Median values of differences in sandbar-median and -maximum height between the spring and summer survey periods indicated decreases of 0.83 and $0.81 \mathrm{ft}$, respectively, for collocated sandbar pairs. Differences in the same statistics for sandbar pairs compared between spring and fall survey periods indicated decreases of 0.73 and $0.99 \mathrm{ft}$, respectively; and between the summer and fall survey periods indicated a decrease of $0.09 \mathrm{ft}$, for each statistic. Results from Wilcoxon signed-rank tests of seasonal data pairs from collocated sandbars indicated that differences in median and maximum heights between the spring and summer survey seasons and the spring and fall survey seasons were significant.

One of the primary aims of the study was to characterize the height of sandbars relative to the stage of formative flows. The height of sandbars during the spring survey was of particular interest because these bars were assumed to have been formed by the 2010 instantaneous peak discharge, which is the third highest measured discharge on record in the study area. Sandbar heights surveyed during the spring survey period indicated that, although the high platform of sandbars can approach the maximum stage of formative flow events, this height is rare, and more often the highest part of sandbars is $1-2 \mathrm{ft}$ less than the formative stage. Furthermore, between about 10 and 50 percent of measured heights from the spring 
survey would have been inundated by the 2011 high discharge of $45,400 \mathrm{ft}^{3} / \mathrm{s}$ (a discharge 67 percent less than the 2010

flood), and more than 98 percent of measured heights from the spring survey would have been inundated by a flow of about $85,000 \mathrm{ft}^{3} / \mathrm{s}$ (a discharge about 38 percent less than the 2011 flood). Although the methods used for the study differ from previous studies in the LPR, the estimations of bar heights are consistent with previous studies which, have indicated sandbars formed between 0.9 and 4.2 feet lower than their respective formative stages.

The streamwise distribution of emergent sandbar area did not change substantially among the three survey periods. A comparison of plots of the longitudinal distribution of sandbar area, normalized as percentage of total sandbar area, indicated that river reaches with abundant emergent sandbar area tended to be the same across the three survey periods. Between spring and fall survey periods, the median change in the fraction of total emergent sandbar area, tabulated by river mile, was a decrease of only 0.21 percentage point, and the interquartile range of such net changes was from -1.32 to 1.06 percentage points.

When compared among collocated sandbar pairs, shifts in sandbar locations, measured as shifts in sandbar polygon centroid between survey seasons, indicated that overall shifts in the areal centroid tended to be small, with the largest shifts occurring in mid-channel sandbars between the spring and summer survey seasons (the median streamwise shift for collocated pairs was $0.05 \mathrm{mi}$ ).

Replicate differential-grade global-positioning system (DGPS) surveys of sandbar area were performed on 13 sandbars across much of the range of sandbar sizes present during the survey periods, and 14 percent of all measured sandbars were replicated. The mean relative difference in sandbar area between original and replicate DGPS measurements was 0.62 percent of the original measurement, and all replicate measurements were within 5 percent of the original survey. The relative differences in area generally were both positive and negative, and magnitudes were evenly distributed across the range of sandbar sizes measured. Results from Wilcoxon signed-rank comparisons of replicate pairs indicated that differences in area between replicate measurements were not significantly different from zero.

Differences in sandbar area between measurements made with the higher-precision laser total station and those made with the handheld DGPS indicated that the overall size of areas obtained using the DGPS is likely within 5 percent of the overall size of areas obtained using the laser total station. The close agreement between the overall sandbar area sizes obtained using the two methods indicates that the DGPS method likely is adequate for obtaining estimates of emergent sandbar area within 5 percent of the actual size.
Original and replicate sandbar height measurements, paired by ranks and surveyed with the rapid-assessment method, indicated that measured sandbar heights did not vary substantially between replicate measurements having slight differences in the placement of the survey grid. The mean difference between ranked-paired original and replicate measurements of sandbar height was $-0.002 \mathrm{ft}$, and ranged from -1.15 to $0.48 \mathrm{ft}$ for individual spot heights. Results from Wilcoxon signed-rank tests of 11 replicate pairs of sandbar-median and -maximum measured heights indicated that differences between data pairs are insignificant.

A comparison of measurements of sandbar and nest heights relative to cumulative topographic distributions generated from detailed total station surveys indicated that technicians could adequately identify and measure the highest part of a sandbar (high platform). Measurements of spot heights generated using the rapid-assessment method ranged from the 51 st to the 98th percentiles of sandbar height frequency distributions. At the two sandbars where several nest heights were measured, individual nest heights ranged between the 62nd and 99th percentile of sandbar heights. Although nest heights only were measured at two sandbars, a comparison of the range of high-platform heights obtained by the rapidassessment method and the range of surveyed heights of nests indicated that at least the highest one-half of measured highplatform heights overlapped with and adequately represented the range of nest heights observed in 2011.

Sandbar data presented in this report represent only three seasons within a single calendar year and sandbar configurations chiefly affected by, at most, two high-discharge events (in 2010 and 2011). Without additional data collected over several more years and several more high-flow events, it is unclear whether the results of this study show long- or shortterm sandbar dynamics; therefore, the time scale over which they can be applied is similarly uncertain. Data from this study and evidence from previous studies indicate that longitudinal patterns and trends of emergent sandbar geometry exist in the LPR. The reporting of such patterns in multiple studies indicates a potential to isolate combinations of morphologic, hydrologic, and hydraulic conditions tending to favor deposition or persistence of mid-channel sandbars with characteristic geometries and surrounding environments that combine to create on-river habitats frequently selected for nesting by terns and plovers in the LPR. With continued monitoring of sandbar dynamics, areas of the LPR that consistently produce habitat favored by nesting colonies of terns and plovers potentially could be quantified and identified. Such analyses would provide valuable information for planning and permitting of future river corridor development, infrastructure routing, and construction projects, as well as for constructing or restoring persistent and successful tern and plover habitats in sand-bed rivers elsewhere on the Great Plains. 


\section{References Cited}

Ashmore, P.E., 1993, Anabranch confluence kinetics and sedimentation processes in gravel-braided streams, in Best, J.L., and Bristow, C.S., eds., Braided Rivers: Geological Society of London Special Publication 75, p. 129-146.

Ashtech LLC, 2010, Mobile Mapper CX-Product specification sheet: Santa Clara, Calif., Ashtech Limited Liability Co., 4 p.

Ashworth, P.J., 1996, Mid-channel bar growth and its relationship to local flow strength and direction: Earth Surface Processes and Landforms, v. 21, p. 103-123.

Ashworth, P.J., Best, J.L., Roden, J.E., Bristow, C.S., and Klaassen, G.J., 2000, Morphological evolution and dynamics of a large, sand, braid-bar, Jamuna River, Bangledesh: Sedimentology, v. 47, p. 533-555.

Bagnold, R.A., 1977, Bed load transport by natural rivers: Water Resources Research, v. 13, p. 303-312.

Bentall, R., 1991, Facts and figures about Nebraska rivers: Lincoln, University of Nebraska, Conservation and Survey Division, Water Supply Paper No. 73, 16 p.

Bentall, R., and Shaffer, F.B., 1979, Availability and use of water in Nebraska, 1975: Lincoln, University of Nebraska, Conservation Survey Division, Nebraska Water Survey Paper 48, $121 \mathrm{p}$.

Best, J.L., and Rhoads, B.L., 2008, Sediment transport, bed morphology, and sedimentology of river channel confluences, in Rice, S.P, Roy, A.G., and Rhoads, B.L., eds., River confluences, tributaries, and the fluvial network: Chichester, United Kingdom, Wiley, p. 45-72.

Blodgett, R.H., and Stanley, K.O., 1980, Stratification, bedforms, and discharge relations of the Platte braided river system, Nebraska: Journal of Sedimentary Petrology, v. 50, p. $139-148$.

Bridge, J.S., 2003, Rivers and floodplains-Forms, processes, and sedimentary record: Oxford, United Kingdom, Blackwell Publishing, $491 \mathrm{p}$.

Brown, M.B., Burbach, M.E., Dinan, J., Held, R.J., Johnson, R.J., Jorgensen, J.G., Lackey, J., Marcus, J.F., Matkin, G.S., and Thody, C.M., 2011a, Nebraska's Tern and Plover Conservation Partnership-A model for sustainable conservation of threatened and endangered species: Wader Study Group Bulletin, v. 118, p. 22-25.

Brown, M.B., and Jorgensen, J.G., 2008, 2008 interior least tern and piping plover monitoring, research, management, and outreach report for the lower Platte River, Nebraska: Lincoln, Tern and Plover Conservation Partnership and Nebraska Game and Parks Commission, Joint Report, 60 p.
Brown, M.B., and Jorgensen, J.G., 2009, 2009 interior least tern and piping plover monitoring, research, management, and outreach report for the lower Platte River, Nebraska: Lincoln, Tern and Plover Conservation Partnership and Nebraska Game and Parks Commission, Joint Report, 76 p.

Brown, M.B., and Jorgensen, J.G., 2010, 2010 interior least tern and piping plover monitoring, research, management, and outreach report for the lower Platte River, Nebraska: Lincoln, Tern and Plover Conservation Partnership and Nebraska Game and Parks Commission, Joint Report, 70 p.

Brown, M.B., Jorgensen, J.G., and Dinan, L.R., 2011b, 2011 interior least tern and piping plover monitoring, research, management, and outreach report for the lower Platte River, Nebraska: Lincoln, Tern and Plover Conservation Partnership and Nebraska Game and Parks Commission, Joint Report, $50 \mathrm{p}$.

Costa, J.E., and O'Conner, J.E., 1995, Geomorphically effective floods in Costa, J.E., Miller, A.J., Potter, K.W., and Wilcock, P.R., eds., Natural and anthropogenic influences in fluvial geomorphology: American Geophysical Union, Geophysical Monograph 89, p. 45-55.

Crowley, K.D., 1983, Large-scale bed configurations (macroforms), Platte River Basin, Colorado and NebraskaPrimary structures and formative processes: Geological Society of America Bulletin, v. 94, p. 117-133.

Dietsch, B.J., Godberson, J.A., and Steele, G.V., 2009, Trends in streamflow characteristics of selected sites in the Elkhorn River, Salt Creek, and Lower Platte River, eastern Nebraska, 1928-2004, and evaluation of streamflows in relation to instream-flow criteria: U.S. Geological Survey Scientific Investigations Report 2009-5011, 93 p. (Also available at http://pubs.er.usgs.gov/publication/sir20095011.)

Dinehart, R.L., 2002, Bedform movement recorded by sequential single-beam surveys in tidal rivers: Journal of Hydrology, v. 258, p. 25-39.

Elliott, C.M., 2011, Geomorphic classification and evaluation of channel width and emergent sandbar habitat relations on the lower Platte River, Nebraska: U.S. Geological Survey Scientific Investigations Report 2011-5028, 22 p. (Also available at http://pubs.er.usgs.gov/publication/ sir20115028.)

Elliott, C.M., Hughman, B.L., and Jacobson, R.B., 2009, Geomorphic classification of the lower Platte River, Nebraska: U.S. Geological Survey Scientific Investigations Report 2009-5198, 29 p. (Also available at http://pubs.er.usgs.gov/ publication/sir20095198.) 
Eschner, T.R., Hadley, R.F., and Crowley, K.D., 1983, Hydrologic and morphologic changes in channels of the Platte River Basin in Colorado, Wyoming, and Nebraska-A historical perspective: U.S. Geological Survey Professional Paper 1277-A, 39 p.

Fenneman, N.M., 1928, Physiographic divisions of the United States: Annals of the Association of American Geographers, v. 17, p 261-353.

Ginting, Daniel, and Zelt, R.B., 2008, Temporal differences in flow depth and velocity distributions and hydraulic microhabitats near bridges of the lower Platte River, Nebraska, 1934-2006: U.S. Geological Survey Scientific Investigations Report 2008-5054, 98 p. (Also available at $h t t p: / /$ pubs.er.usgs.gov/publication/sir20085054.)

Ginting, Daniel, Zelt, R.B., and Linard, J.I., 2008, Temporal differences in the hydrologic regime of the lower Platte River, Nebraska, 1895-2006: U.S Geological Survey Scientific Investigations Report 2007-5267, 43 p. (Also available at http://pubs.er.usgs.gov/publication/sir20075267.)

Grigg, N., McCarthy, C., Lawrence, B., Ockerman, D., 2012, Review of the regulation of the Missouri River mainstem reservoir system during the flood of 2011: Missouri River Flood Task Force, Missouri River Independent Review Panel report to the U.S. Army Corps of Engineers, Omaha District, 93 p., accessed January 17. 2013, at $h t t p: / / w w w . n w d-m r . u s a c e . a r m y . m i l / r c c / M R F T F / d o c s /$ MRIndependentReviewPanel.pdf.

Helsel, D.R., and Hirsch, R.M., 2002, Statistical methods in water resources: U.S. Geological Survey Techniques of Water Resources Investigations, book 4, chap. A3, 522 p. (Also available at http://pubs.er.usgs.gov/publication/ twri04A3.)

Holmes, R.R., 2010, Measurement of bedload transport in sand-bed rivers-A look at two indirect sampling methods, in Gray, J.R., Laronne, J.B., and Marr, J.D.G., Bedloadsurrogate monitoring technologies: U.S. Geological Survey Scientific Investigations Report 2010-5091, p. 236-252. (Also available at http://pubs.usgs.gov/ sir/2010/5091/papers/listofpapers.html)

Joeckel, R.M., and Henebry, G.M., 2008, Channel and island change in the lower Platte River, eastern Nebraska, USA, 1855-2005: Geomorphology, v. 102, p. 407-418.

Johnson, W.C., 1994, Woodland expansions in the Platte River, Nebraska-Patterns and causes: Ecological Monographs, v. 64, p. 45-84.

Jorgensen, J.G., Brown, M.B., and Tyre, A.J., 2012, Channel width and least tern and piping plover nesting incidence on the lower Platte River, Nebraska: Great Plains Research, v. 22, p. $59-67$.
Kirsch, E.M., 1996, Habitat selection and productivity of least terns on the lower Platte River, Nebraska: Wildlife Monographs, no. 132, p. 3-48.

Leeder, M., 1999, Sedimentology and sedimentary basinsFrom turbulence to tectonics: Oxford, United Kingdom, Blackwell Publishing, $592 \mathrm{p}$.

Leopold, L.B., and Wolman, M.G., 1957, River channel patterns-Braided, meandering, and straight: U.S. Geological Survey Professional Paper 282-B, 85 p.

Lott, C.A., and Willey, R.L., 2012, Effects of dam operations on least tern nesting habitat and reproductive success below Keystone Dam on the Arkansas River: Vicksburg, Miss., U.S. Army Corps of Engineers, Engineering and Research Development Center, $101 \mathrm{p}$.

Loup River Public Power District, 2008, Loup River Hydroelectric Project-FERC project No. 1256-Pre-application document, volume 1: Columbus, Nebr., Loup River Public Power District [variously paged].

Meade, R.H., Rayol, J.M., Da Conceicao, S.C., and Natividade, J.R.G., 1991, Backwater effects in the Amazon River Basin of Brazil: Environmental Geology, v. 18, p. 105-114.

Mosley, M.P., 1976, An experimental study of channel confluences: Journal of Geology, v. 84, p. 535-562.

National Research Council, 2005, Endangered and threatened species of the Platte River: Washington, D.C., National Academies Press, 299 p.

Ore, H.T., 1964, Some criteria for recognition of braided stream deposits: Rocky Mountain Geology, v. 3, p. 1-14.

Parham, J.E., 2007, Hydrologic analysis of the lower Platte River from 1954-2004, with special emphasis on habitats of the endangered least tern, piping plover, and pallid sturgeon: Lincoln, Nebraska Game and Parks Commission, contracted report, $174 \mathrm{p}$.

Smith, N.D., 1970, The braided stream depositional environment-Comparison of the Platte River with some Silurian clastic rocks, North-Central Appalachians: Geological Society of America Bulletin, v. 81, p. 2993-3014.

Smith, N.D., 1971, Transverse bars and braiding in the lower Platte River, Nebraska: Geological Society of America Bulletin, v. 82, p. 3407-3420.

Sokkia Company, 2004, Sokkia Series 130R—Reflectorless total stations - Specifications sheet: Knagawa, Japan, Sokkia Company Ltd., International Sales Department, 8 p. 
U.S. Army Corps of Engineers, 2011, Final programmatic environmental impact statement for the mechanical and artificial creation and maintenance of emergent sandbar habitat in the riverine segments of the upper Missouri River: Omaha, Nebr., U.S. Army Corps of Engineers, Omaha District [variously paged].

U.S. Geological Survey, 2010, Topographic map of the Plattsmouth quadrangle, Nebraska-Iowa: U.S. Geological Survey Topographic Quadrangle Map, 7.5-Minute Series, scale 1:24,000 (photograph revised 2008).

U.S. Geological Survey, 2011, Water-resources data for the United States, water year 2010: U.S. Geological Survey Water-Data Report WDR-US-2010, with Section on station 06805500, 18 p., accessed January 17, 2013, at http://wdr. water.usgs.gov/wy2010/pdfs/06805500.2010.pdf.
U.S. Geological Survey, 2012, Water-resources data for the United States, water year 2011: U.S. Geological Survey Water-Data Report WDR-US-2011, with Section on station 06805500, 18 p., accessed January 17, 2013, at $h t t p: / / w d r$. water.usgs.gov/wy2011/pdfs/06805500.2011.pdf.

Williams, G.P., 1978, The case of the shrinking channels-The North Platte and Platte Rivers in Nebraska: U.S. Geological Survey Circular 781, 48 p. (Also available at $h t t p: / / p u b s$. er.usgs.gov/publication/cir781.)

Ziewitz, J.W., Sidle, J.G., and Dinan, J.J., 1992, Habitat conservation for nesting least terns and piping plovers on the Platte River, Nebraska: Prairie Naturalist, v. 24, p. 1-19. 



\section{Appendixes}




\section{Appendix 1. Estimates of Error in Measured Sandbar Height Associated with Errors in Estimation of Water Travel Time}

A fundamental component of the estimations of sandbar height made for the study was estimation of water travel time between the four streamflow-gaging stations around or within the study area (see equations 1 through 3 in "Approach and Methods"). Water travel time was estimated between each pair of streamflow-gaging stations for each day of each survey period using a stage-correlation method that iteratively added time offsets to the upstream station's record for a 72-hour window of the instantaneous stage records (15-minute time series) until the correlation between the two records, as measured using Pearson's correlation coefficient (Helsel and Hirsch, 2002), was maximized (see "Approach and Methods" for an additional description of the stage-correlation method).

Two types of travel times were estimated: (1) the incremental-reach average travel time $(t)$, and (2) the studysegment average travel time $(T)$. The incremental-reach average travel time is the travel time of water between adjacent streamflow-gaging stations along the larger study segment, and was the travel time used to interpolate a stage value corresponding to each individual water-surface height measurement. Interpolated stage values were referenced to the nearest streamflow-gaging station with a stage-discharge relation. The study-segment average travel time is the travel time of water between the most upstream and most downstream streamflowgaging stations on any given day, and was used as a qualitycontrol measure. By continuity, $T$ should be equal to the sum of all $t$ 's:

$$
T \cong \sum_{i}^{n} t_{i}
$$

where

$$
\begin{gathered}
i \quad \text { is an incremental reach bounded by two } \\
\text { streamflow-gaging stations, and } \\
n \quad \text { is the total number of incremental reaches } \\
\text { within the study segment. }
\end{gathered}
$$

In the case of this study along the LPR in eastern Nebraska, three incremental reaches, were used to estimate travel time (in order from upstream to downstream): (1) Ashland (USGS station 06801000) to South Bend (USGS station 06805020), (2) South Bend to Louisville (USGS station 06805500), and (3) Louisville to La Platte (USGS station 06805570). The term "closure" is used to describe the continuity-based balance between separately calculated travel times for the left and right sides of equation 1-1. Perfect closure would indicate no travel-time differential between the two sides of equation 1-1; in the case of this study, departure from perfect closure is measured in unit time differentials of 15-minute increments because this was the recording frequency in the stage records at each streamflow-gaging station. Two closure estimates were made for this study: (1) an "incremental closure" estimate between Ashland and Louisville, and (2) a "total closure" estimate between Ashland and La Platte. Thus, a measure of uncertainty in any given water-surface measurement is the corresponding estimate of departure from closure (in units of 15-minute increments) multiplied by the maximum 15-minute stage change during the respective survey period. The associated measurements of sandbar height, which are related to water stage at the bar's edge, have an uncertainty proportional to the uncertainty in the water-surface height.

Estimates of water travel time between streamflow-gaging stations indicated that incremental average water velocities within the study area varied from 1.1 to 2.8 miles per hour (mi/hr), and study-segment average water velocities varied from 1.4 to $2.1 \mathrm{mi} / \mathrm{hr}$ (tables 1-1 through 1-3). Incremental water velocities generally were greatest in the South Bend-toLouisville reach, and least in the Louisville-to-La Platte reach. Average water velocities in the Louisville-to-La Platte reach potentially were decreased by backwater effects from the Missouri River during the spring and summer survey periods, causing water velocities to be less than $1.4 \mathrm{mi} / \mathrm{hr}$ on average. Water velocities were most uniform across increments during the fall survey, when water levels in both the lower Platte and Missouri Rivers were the lowest of those during the three survey seasons.

For incremental closure, results indicated that the absolute value of travel-time closure error between the Ashland and Louisville gages was no more than 30 minutes; for the summer and fall surveys, closure was perfect about half of all days (tables 1-1 through 1-3). Although only 7 estimates of total closure could be made for the total of 12 survey days, these estimates indicate that the absolute value of total closure error was always less than 30 minutes, and closure was perfect in 3 of 7 cases.

Maximum stage changes over 15-minute increments as recorded at streamflow-gaging stations during each survey period varied from 0.04 to $0.11 \mathrm{ft}$, and averaged $0.04-$ $0.07 \mathrm{ft}$ (table 1-4). Multiplying the range of maximum 15-minute stage changes by the maximum (30 minutes, or 2 units) and minimum (-30 minutes, or -2 units) travel-time closure errors, an estimate of the maximum range of the potential error in sandbar height measurement points (for a given day with imperfect closure) caused by errors in water travel time estimates is $+/-0.08$ for at least one reach per survey period to $+/-0.22 \mathrm{ft}$ for the upstream reach near Ashland during the summer survey period. 
Table 1-1. Correlation, travel time, and estimated water velocity from a comparison of instantaneous stage records between selected gaging stations in lower Platte River, Nebraska, for time periods centered on individual days during the spring survey period, 2011.

[Spring survey period defined as April 6-April 12, 2011. Unless otherwise indicated, correlation coefficients and travel times were calculated using the 15-minute stage record, applied over a maximum 72-hour time window, centered on the day indicated. See "Approach and Methods" for additional explanation of correlation technique. Values in italics indicate travel time was calculated using data centered on a different day than indicated. - , no data; NA, closure was not calculated]

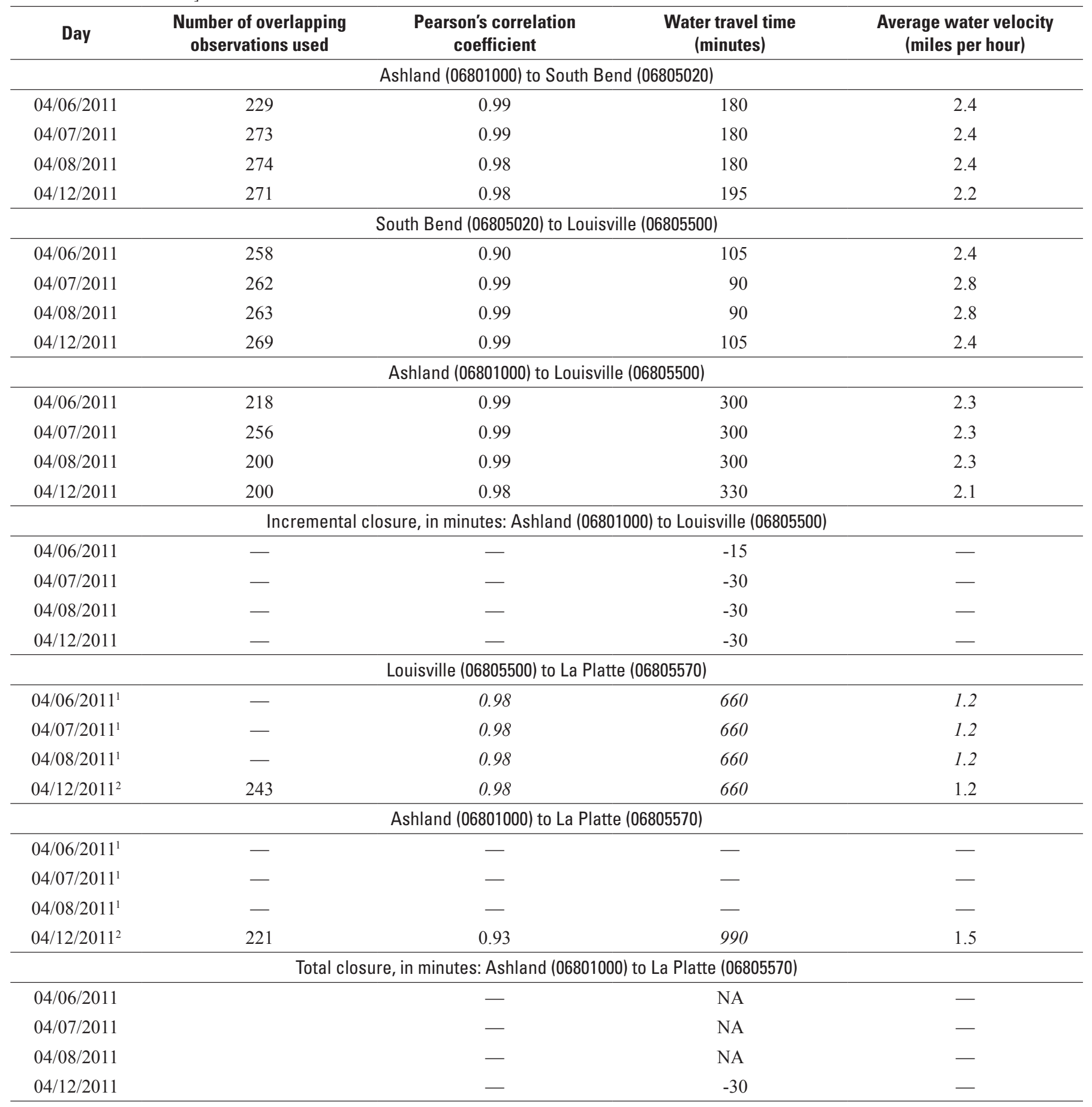

${ }^{1}$ Stage data not available for La Platte gage on this day; travel time value was calculated on different day than indicated. Pearson's correlation coefficient shown does not correspond to day indicated.

${ }^{2}$ Travel time value calculated using data from 4/12/2011 to 4/15/2011. 
Table 1-2. Correlation, travel time, and estimated water velocity from a comparison of instantaneous stage records between selected gaging stations in lower Platte River, Nebraska, for time periods centered on individual days during the summer survey period, 2011.

[Summer survey period defined as July 26-August 2, 2011. Unless otherwise indicated, correlation coefficients and travel times were calculated using the 15-minute stage record, applied over a maximum 72-hour time window, centered on the day indicated. See "Approach and Methods" for additional explanation of correlation technique. Values in italics indicate travel time was calculated using data centered on a different day than indicated. -, no data; NA, closure was not calculated]

\begin{tabular}{|c|c|c|c|c|}
\hline Day & $\begin{array}{c}\text { Number of overlapping } \\
\text { observations used }\end{array}$ & $\begin{array}{c}\text { Pearson's correlation } \\
\text { coefficient }\end{array}$ & $\begin{array}{c}\text { Water travel time } \\
\text { (minutes) }\end{array}$ & $\begin{array}{c}\text { Average water velocity } \\
\text { (miles per hour) }\end{array}$ \\
\hline \multicolumn{5}{|c|}{ Ashland (06801000) to South Bend (06805020) } \\
\hline $07 / 26 / 2011$ & 248 & 0.99 & 195 & 2.2 \\
\hline $07 / 27 / 2011$ & 247 & 0.98 & 195 & 2.2 \\
\hline $07 / 28 / 2011$ & 252 & 0.97 & 210 & 2.0 \\
\hline $07 / 29 / 2011$ & 177 & 0.97 & 225 & 1.9 \\
\hline $07 / 26 / 2011$ & 281 & 1.00 & 105 & 2.4 \\
\hline $07 / 27 / 2011$ & 281 & 1.00 & 105 & 2.4 \\
\hline $07 / 28 / 2011$ & 281 & 1.00 & 105 & 2.4 \\
\hline $07 / 29 / 2011$ & 204 & 0.99 & 105 & 2.4 \\
\hline $07 / 28 / 2011$ & 245 & 0.97 & 315 & 2.2 \\
\hline $07 / 29 / 2011$ & 224 & 0.98 & 315 & 2.2 \\
\hline $08 / 02 / 2011$ & 251 & 1.00 & 315 & 2.2 \\
\hline \multicolumn{5}{|c|}{ Incremental closure, in minutes: Ashland (06801000) to Louisville (06805500) } \\
\hline $07 / 26 / 2011$ & - & - & -15 & - \\
\hline $07 / 27 / 2011$ & - & - & -15 & - \\
\hline $07 / 28 / 2011$ & - & - & 0 & - \\
\hline $07 / 29 / 2011$ & - & - & 15 & - \\
\hline $08 / 02 / 2011$ & - & - & 15 & - \\
\hline \multicolumn{5}{|c|}{ Louisville (06805500) to La Platte (06805570) } \\
\hline $07 / 26 / 2011^{2}$ & - & - & - & - \\
\hline $07 / 27 / 2011^{1}$ & 218 & 0.33 & 1,050 & 1.4 \\
\hline $07 / 28 / 2011^{1}$ & 218 & 0.33 & 1,050 & 1.4 \\
\hline $07 / 29 / 2011^{3}$ & - & - & - & - \\
\hline $08 / 02 / 2011^{3}$ & - & - & - & - \\
\hline \multicolumn{5}{|c|}{ Total closure, in minutes: Ashland (06801000) to La Platte (06805570) } \\
\hline $07 / 26 / 2011$ & - & - & NA & - \\
\hline $07 / 27 / 2011$ & - & - & 0 & - \\
\hline $07 / 28 / 2011$ & - & - & 15 & - \\
\hline $07 / 29 / 2011$ & - & - & NA & - \\
\hline $08 / 02 / 2011$ & - & - & NA & - \\
\hline
\end{tabular}

${ }^{1}$ Travel time value calculated using data centered between 0800 hours on July 26th through 0800 hours on July 29th.

${ }^{2}$ Travel time value not calculated because of backwater effect on stage height.

${ }^{3}$ Travel time not calculated because of gaging-station malfunction. 
Table 1-3. Correlation, travel time, and estimated water velocity from a comparison of instantaneous stage records between selected gaging stations in lower Platte River, Nebraska, for time periods centered on individual days during the fall survey period, 2011.

[Fall survey period defined as October 31-November 4, 2011. Unless otherwise indicated, correlation coefficients and travel times were calculated using the 15-minute stage record, applied over a maximum 72-hour time window, centered on the day indicated. See "Approach and Methods" section for additional explanation of correlation technique. - , no data]

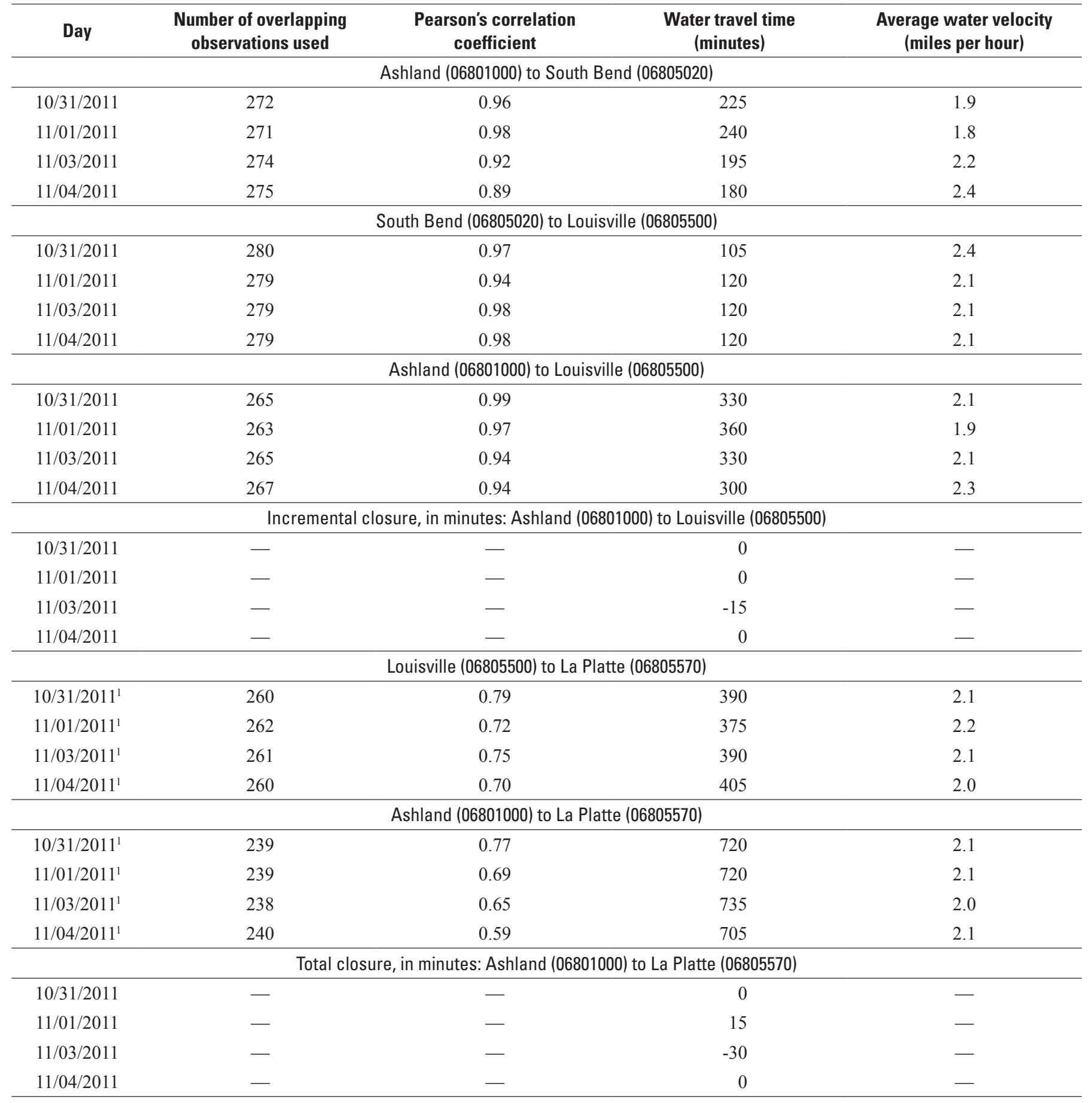

${ }^{1}$ Stage record at La Platte affected by sand burial of pressure line. 
Table 1-4. Maximum 15-minute stage changes at selected gaging stations in the lower Platte River, Nebraska, by survey period, 2011.

[Spring survey period defined as April 6-April 12, 2011. Summer survey period defined as July 26-August 2, 2011. Fall survey period defined as October 31-November 4, 2011. All values calculated using 15-minute timeseries record available from the U.S. Geological Survey National Water Information System. NA, stage record condsidered unsuitable for analysis.]

\begin{tabular}{|c|c|c|c|c|}
\hline \multirow[b]{2}{*}{$\begin{array}{l}\text { Survey } \\
\text { period }\end{array}$} & \multicolumn{4}{|c|}{$\begin{array}{l}\text { Maximum 15-minute stage changes by gaging station, } \\
\text { in feet }\end{array}$} \\
\hline & $\begin{array}{c}\text { Platte } \\
\text { River near } \\
\text { Ashland } \\
(06801000)\end{array}$ & $\begin{array}{c}\text { Platte } \\
\text { River at } \\
\text { South Bend } \\
(06805020)\end{array}$ & $\begin{array}{c}\text { Platte } \\
\text { River at } \\
\text { Louisville } \\
\text { (06805500) }\end{array}$ & $\begin{array}{c}\text { Platte River } \\
\text { at La Platte } \\
(06805570)\end{array}$ \\
\hline Spring & 0.05 & 0.05 & 0.04 & 0.04 \\
\hline Summer & 0.11 & 0.06 & 0.06 & 0.04 \\
\hline Fall & 0.04 & 0.08 & 0.05 & NA \\
\hline Average & 0.07 & 0.06 & 0.05 & 0.04 \\
\hline
\end{tabular}




\section{Appendix 2. Validation of Predicted Bar Heights Using Observations of Inundation from Remote Time-Lapse Photographs}

Sandbar inundation by annual maximum or other peak discharge events is one of the common causes of tern and plover nest failure in the lower Platte River. Therefore, efforts to document sandbar heights are important to enable prediction of such events in the future. Estimations of sandbar heights for this study were made across varying reach lengths using the stage-discharge rating relations from nearby streamflowgaging stations. Although the authors believe these estimations of height were adequate to predict inundation status, validation of predicted sandbar heights may add additional confidence to the estimation methods for sandbar height described in this report. However, the difficulty in validation lies in maintaining readiness for an annual maximum or other peak discharge event to occur, and collecting observations of sandbar inundation coinciding with the event. To capture observations of sandbar inundation extent during whatever high-discharge events occurred, the authors deployed two time-lapse reconnaissance digital cameras on an observation tower near South Bend, Nebr (fig. 2-1). The cameras, focused on reaches of the lower Platte River, were fixed with one facing upstream, the other facing obliquely downstream, and programmed to take photographs at 15-minute intervals during all daylight hours for all days during the study period.

Validation of the extent of inundation during high flows was assessed for four surveyed sandbars visible in the field of view of these two time-lapse cameras. The four sandbars were first surveyed during the spring survey period on April 7, 2011, and 4-9 measurements of sandbar height were taken on each bar's high platform. The validation procedure for sandbar height consisted of two primary steps: (1) predict the number of individual height measurements that would be inundated for a stage rise associated with a particular high-magnitude discharge on a particular day, and (2) visually estimate the extent of sandbar inundation represented in the images of that sandbar taken by the time-lapse cameras on that same day. The first step was completed using the stage-discharge rating table of the nearest streamflow-gaging station, which was in this case the Platte River at Louisville, Nebraska (USGS station 06805500). Extent of inundation was predicted for the high-discharge events that occurred on May 27, 2011 $\left(45,400 \mathrm{ft}^{3} / \mathrm{s}\right)$ and June 28, $2011\left(43,400 \mathrm{ft}^{3} / \mathrm{s}\right)$, and was predicted using only measurements of height from the spring survey. Estimation of extent of inundation in the time-lapse photographs was made by simple visual comparison of photographs taken at lower discharges (that is, in the weeks prior to the floods), with photographs taken during the peak of the floods. Because the photographs were oblique, visual estimations were limited to bin sizes of 20 percent ( 0 , greater than zero and less than 20 percent, 20 to less than 40 percent, 40 to less than 60 percent, 60 to less than 80 percent, 80 to less than 100 percent, and 100 percent). Although methods exist to extract more precise estimates of area from oblique photographs, the authors considered this method adequate for the purposes of validating sandbar inundation.

Although only four sandbars with measured height of the high platform were visible in time-lapse photographs, the observations of sandbar inundation from the photographs indicate very good agreement with predictions of inundation extent based on sandbar height (table 2-1). Two of four sandbars predicted to be 100 percent inundated by both the May 27 and June 28 high-discharge events, were observed to be entirely inundated in time-lapse photographs taken during the associated peak discharges. Similarly, two of the four sandbars were predicted to have inundation of more than 60 percent of surveyed points on the high platform (table 2-1), and time-lapse photographs of both of these sandbars showed that the May (fig. 2-1) and June high discharges inundated an estimated 80 percent or more of each bar.

Table 2-1. Predicted number of spot measurements of sandbar height inundated and estimated percentage of sandbar area inundated, as shown by time-lapse photography, for four sandbars and two high-magnitude discharges, lower Platte River, Nebraska, 2011.

[No., number; $\mathrm{ft}^{3} / \mathrm{s}$, cubic feet per second; >, greater than]

\begin{tabular}{|c|c|c|c|c|c|c|}
\hline \multirow[b]{2}{*}{$\begin{array}{c}\text { Sandbar } \\
\text { no. }\end{array}$} & \multirow[b]{2}{*}{$\begin{array}{c}\text { Date } \\
\text { surveyed }\end{array}$} & \multirow{2}{*}{$\begin{array}{c}\text { No. } \\
\text { height } \\
\text { measure- } \\
\text { ments }\end{array}$} & \multicolumn{2}{|c|}{ Peak discharge of $45,400 \mathrm{ft}^{3} / \mathrm{s}$ on May $27,2011^{1}$} & \multicolumn{2}{|c|}{ Peak discharge of $43,400 \mathrm{ft}^{3} / \mathrm{s}$ on June $28,2011^{2}$} \\
\hline & & & $\begin{array}{l}\text { No. of points } \\
\text { predicted to be } \\
\text { inundated }\end{array}$ & $\begin{array}{l}\text { Estimated percent of sandbar } \\
\text { inundated, from visual analysis } \\
\text { time-lapse photographs }\end{array}$ & $\begin{array}{l}\text { No. of points } \\
\text { predicted to be } \\
\text { inundated }\end{array}$ & $\begin{array}{l}\text { Estimated percent of sandbar } \\
\text { inundated, from visual analysis } \\
\text { time-lapse photographs }\end{array}$ \\
\hline 1 & $04 / 07 / 2011$ & 4 & 4 & 100 & 4 & 100 \\
\hline 2 & $04 / 07 / 2011$ & 9 & 6 & $>80$ & 6 & $>80$ \\
\hline 4 & $04 / 07 / 2011$ & 9 & 7 & $>80$ & 6 & $>80$ \\
\hline
\end{tabular}

${ }^{1}$ Source: U.S. Geological Survey, 2012.

${ }^{2}$ Discharge estimate obtained from 15-minute time-series data at USGS streamflow-gaging station 06805500. 


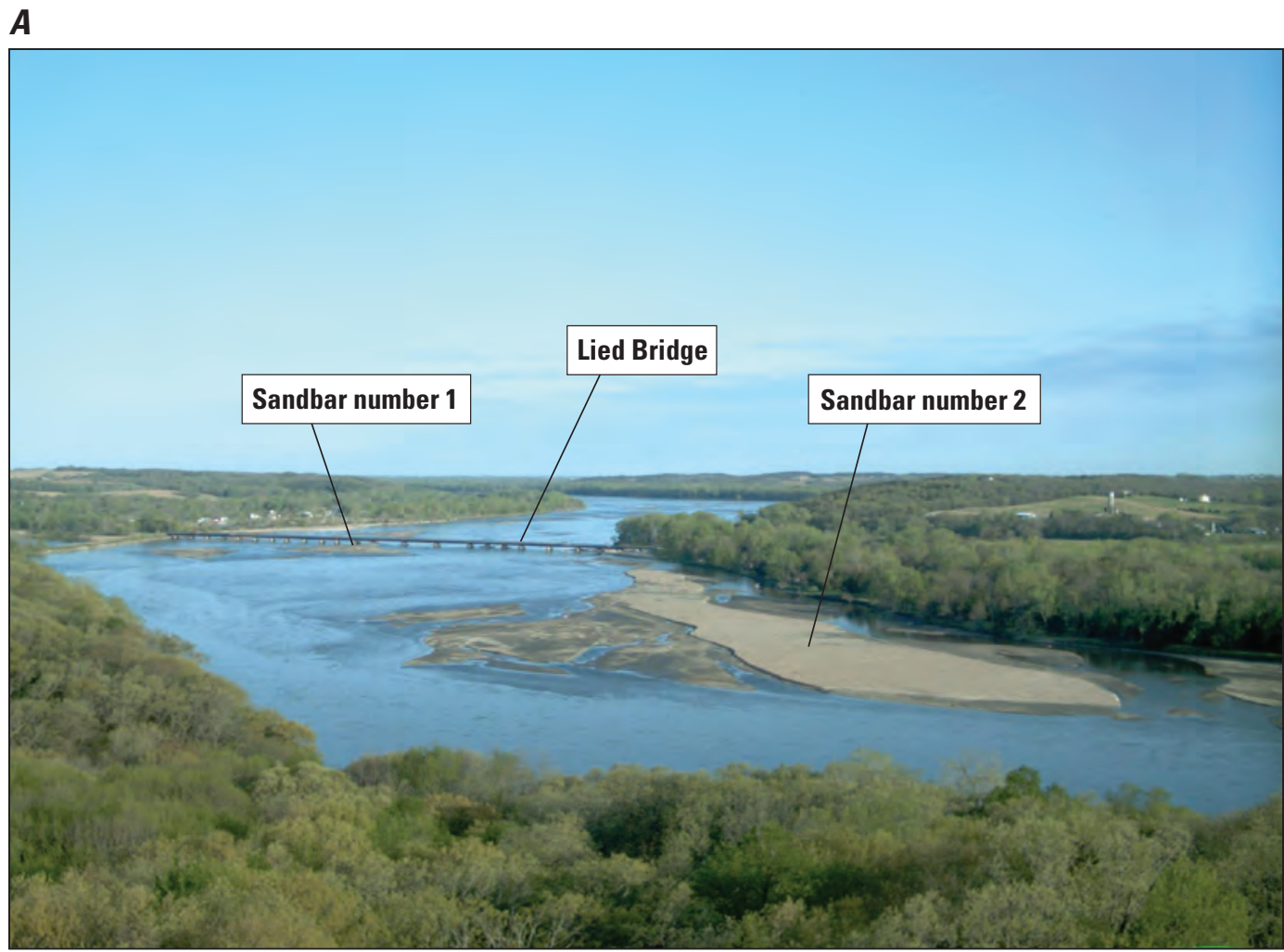

B

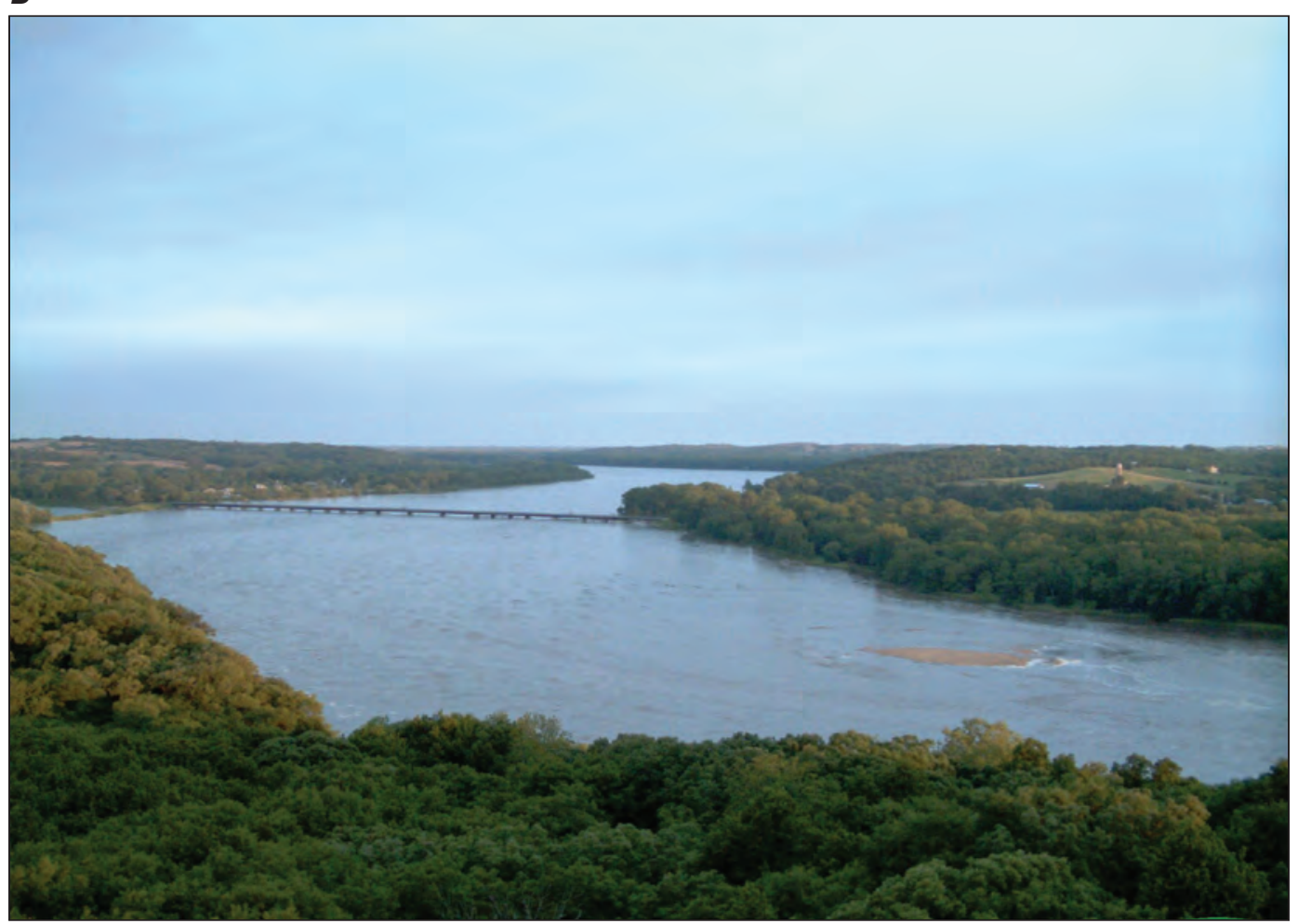

Figure 2-1. Oblique, reconnaissance photographs showing two sandbars used for validation of predicted inundation of sandbar-height survey points; U.S. Geological Survey photographs from tower-mounted timelapse camera facing lower Platte River near South Bend, Nebraska: $(A)$ May 7, 2011 river discharge was about 10,000 cubic feet per second, and $(B)$ May 27, 2011 river discharge was about 44,400 cubic feet per second. River flow is left to right. 


\section{Publishing support provided by:}

Rolla and Tacoma Publishing Service Centers

For more information concerning this publication, contact: Director, USGS Nebraska Water Science Center 5231 South 19th Street

Lincoln, Nebraska 68512

(402) 328-4100

Or visit the Nebraska Water Science Center Web site at: http://ne.water.usgs.gov/ 


